Universidade de São Paulo

Faculdade de Filosofia, Ciências e Letras de Ribeirão Preto

Departamento de Química

Programa de Pós-Graduação em Química

\title{
Derivados Porfirínicos com Potencial Aplicação em Terapia Fotodinâmica. Alterações Estruturais.
}

\author{
Vinícius Silveira Garcia
}

Dissertação apresentada à Faculdade de Filosofia, Ciências e Letras de Ribeirão Preto da Universidade de São Paulo, como parte das exigências para a obtenção do título de Mestre em Ciências, Área: Química

RIBEIRÃO PRETO-SP 
Universidade de São Paulo

Faculdade de Filosofia, Ciências e Letras de Ribeirão Preto

Departamento de Química

Programa de Pós-Graduação em Química

\title{
Derivados Porfirínicos com Potencial Aplicação em Terapia Fotodinâmica. Alterações Estruturais.
}

\author{
Vinícius Silveira Garcia \\ Dissertação de Mestrado
}

Orientador: Prof. Osvaldo Antonio Serra

RIBEIRÃO PRETO-SP 


\section{FICHA CATALOGRÁFICA}

\section{Garcia, Vinícius Silveira}

Derivados Porfirínicos com Potencial Aplicação em Terapia

Fotodinâmica. Alterações Estruturais. Ribeirão Preto, 2008.

$$
94 \text { p. : il. ; } 30 \mathrm{~cm}
$$

Dissertação de Mestrado, apresentada à Faculdade de Filosofia Ciências

e Letras Ribeirão Preto/USP - Área de concentração: Química.

Orientador: Serra, Osvaldo Antonio.

1. Derivados Porfirínicos. 2. Diels-Alder. 3. Fotofísica.

4. Terapia Fotodinâmica. 


\section{SÍNTESE DAS ANTÍTESES}

Só temos consciência do belo,

Quando conhecemos o feio.

Só temos consciência do bom,

Quando conhecemos o mau.

Porquanto, o Ser e o Existir,

Se engendram mutuamente.

O fácil e o dificil se complementam.

O grande e o pequeno são complementares.

O alto e o baixo formam um todo.

O som e o silêncio formam a harmonia.

O passado e o futuro geram o tempo.

Eis porque o sábio age

Pelo não agir,

E ensina sem falar,

Aceita tudo que lhe acontece

Produz tudo e não fica com nada.

O sábio tudo realiza e nada considera seu

Tudo faz - e não se apega à sua obra

Não se prende aos frutos da sua atividade

Termina a sua obra

E está sempre no princípio

E por isto a sua obra prospera.

Lao Tse 
Conta certa lenda, que estavam duas crianças patinando num lago congelado.

Era uma tarde nublada e fria e as crianças brincavam despreocupadas.

De repente, o gelo se quebrou e uma delas caiu, ficando presa na fenda que se formou. A outra, vendo seu amiguinho preso e se congelando, tirou um dos patins e começou a golpear o gelo com todas as suas forças, conseguindo por fim quebrá-lo e libertar o amigo.

Quando os bombeiros chegaram e viram o que havia acontecido, perguntaram ao menino:

- Como você conseguiu fazer isso?

É impossível que tenha conseguido quebrar o gelo, sendo tão pequeno e com mãos tão frágeis!

Nesse instante, um ancião que passava pelo local, comentou:

- Eu sei como ele conseguiu.

Todos perguntaram:

- Pode nos dizer como?

- É simples - respondeu o velho.

- Não havia ninguém ao seu redor, para lhe dizer que não seria capaz 


\section{Dedico esta Dissertação}

Aos meus progenitores, Aparecida e José Carlos que sempre dedicaram suas vidas a proporcionar bons exemplos e uma educação de boa qualidade a mim. Espero que este documento possa de alguma forma suprimir tantas noites de preocupações e tantas lágrimas derrubadas quando a condição financeira era desfavorável e vocês faziam de tudo para manter-me sempre em uma boa instituição de ensino. Hoje espero que as lágrimas sejam de felicidade e de sentimento de dever cumprido.

Ao meu irmão Daniel, o qual sempre recebe muitas cobranças por minha parte, entretanto é porque quero que seja uma pessoa bem melhor que eu sempre fui.

A minha querida Ana Flavia, a muito tempo minha companheira em todos os momentos de altos e baixos. A distância física nos fez cada vez mais unidos. Obrigado pelo amor, paciência, cooperação e companheirismo.

A memória do meu pai, um exemplo a ser seguido, e à memória do meu tio Wanderley, quem um dia despertou em mim a paixão pela quimica. Sou mais um da dinastia dos quimicos, um gosto passado de tio para sobrinho já a três gerações.

A todos os meus familiares, de sangue ou não, que durante o meu periodo de aprendizado me incentivaram, compreenderam minha ausência, acreditaram em meu potencial, possibilitaram uma pousada, etc. Meu eterno agradecimento. 


\section{Agradecimentos}

Primeiramente agradeço a Deus, arquiteto da vida e da inteligência humana. Aquele que a mim deu o dom de aprender e desvendar a ciência.

Ao Prof. Dr. Osvaldo Antônio Serra pela orientação, pela amizade, pela confiança e principalmente pelo apoio oferecido para que eu continuasse a minha formação.

À Profa. Dra. Yassuko Iamamoto pelas ricas discussões sobre a química bioinorgânica e principalmente sobre as potenciais aplicabilidades das porfirinas.

Ao Prof. Dr. Mauricio Gomes Constantino, pelos anos de convivência e principalmente por tudo que aprendi ao seu lado durante minha iniciação científica.

Ao meu grande amigo e co-orientador Dr. Kleber Thiago de Oliveira pela convivência, amizade e grande contribuição não apenas neste trabalho, como também para a minha formação química desde o primeiro ano da graduação.

Ao Prof. Dr. Paulo Marcos Donate, Prof. Dr. José Fernando de Andrade, Prof. Dr. Paulo Olivi, Prof. Dr. Luiz Alberto Beraldo de Moraes, pela amizade e boas risadas nas partidas de futebol.

A todos os demais docentes do departamento de química que de alguma maneira contribuíram para a minha formação e para a elaboração deste trabalho.

Ao Dr. Daniel Frederico, Prof. Dr. Anderson Orzari Ribeiro, pela amizade, pelos ensinamentos, pela boa convivência e participação neste trabalho.

Ao Dr. Claudio Neri pela amizade, apoio e descontração durante as viagens a congressos enquanto estive neste laboratório.

Aos meus amigos Flávio, Marcel, Marco e Walter, companheiros de curso que fizeram do período de graduação uma época que vai deixar muitas lembranças.

Aos amigos Emílio e Ellen, obrigado pela amizade verdadeira. 
À aluna de Iniciação Científica Miriam Fechetia que trabalhou comigo e muito contribuiu para este trabalho.

A todos os amigos do Laboratório, Dr. Daniel, Dr. Kleber, Dr. Claudio, Alexandre, Lucas, Luciano, Carlo, Marcos José, Paulo César, Carlos Frederico, Francisco, Luciana, Christiane, Tatiana, Edimar, Fernanda, Priscilla, Juliana, Ariane, Janaina, Dra. Simone e a todos os quais pude conviver; muito obrigado pela amizade e apoio.

Aos funcionários do Departamento de Química: Lâmia, Bel, Sônia, Emerson, André, Maria, Losane, Mércia, Djalma, Valdir, Dias, Vera, Dora, Virgínia e Olímpia pela amizade e atenção durante todos esses anos.

A todos os funcionários da Seção de Pós-Graduação pela atenção e competência.

A todos que de alguma forma contribuíram para a realização deste trabalho.

À FAPESP pelo apoio financeiro e pela constante atenção com que assiste nossa pesquisa. 


\section{Abreviações}

$[\mathrm{HN}=\mathrm{NH}]-$ Diimida

${ }^{13} \mathrm{C}\{\mathrm{H}\}$ - Carbono Totalmente Desacoplado de Hidrogênio

$\mathrm{Ac}_{2} \mathrm{O}$ - Anidrido Acético

AcOH - Ácido Acético

AMD - Age-related Macular Degeneration

CCD ou TLC - Cromatografia em Camada Delgada (Thin Layer Chromatography)

$\mathrm{CD}_{3} \mathrm{OD}-$ Metanol-d $_{4}$

$\mathrm{CDCl}_{3}$ - Clorofórmio Deuterado

$\mathrm{CH}_{3} \mathrm{OD}-$ Metanol-d

$\mathrm{CH}_{3} \mathrm{PPh}_{3} \mathrm{Br}-$ Brometo de Metiltrifenilfosfina

$\mathrm{CHCl}_{3}-$ Clorofórmio

DBU - 1,8-Diazabiciclo[5.4.0]undec-7-eno

DDQ - 2,3-Dicloro-5,6-diciano-1,4-benzoquinona

DEPT-135 - Distortionless Enhancement by Polarization Transfer - angle $135^{\circ}$

DMAD - Acetilenodicarboxilato de Dimetila

DMAP - Dimetilaminopiridina

DMF - N,N-Dimetilformamida

DMSO - Dimetilsulfóxido

EROs - Espécies Reativas de Oxigênio

ESI-Q-TOF - Electron Spray Ionization-Quadrupole-Time of Flight

ESI-TOF - Electron Spray Ionization - Time of Flight

$\mathrm{Et}_{3} \mathrm{~N}$ - Trietilamina

gCOSY - Correlation Spectroscopy

gHMBC - Heteronuclear Multiple-Bond Correlation

gHMQC - Heteronuclear Multiple-Quantum Correlation

gJres - J resolved

IUPAC - International Union of Pure and Applied Chemistry

$\mathrm{MeOH}-$ Metanol

NOE - Nuclear Overhauser Effect

OAc - Acetato 
$\mathrm{OsO}_{4}$ - Tetra-óxido de Ósmio VIII

p-cloranil - (2,3,5,6-tetraclorobenzoquinona)

$\mathrm{Ph}_{3} \mathrm{P}=\mathrm{CH}_{2}$ - Ileto Metílico de Fósforo

$\mathrm{POCl}_{3}-$ Cloreto de Fosforila ou Oxicloreto de Fósforo

PTSA - Ácido p-Toluenosulfônico

Py - Piridina

RMN de ${ }^{1} \mathrm{H}$ - Espectroscopia de Ressonância Magnética Nuclear de Prótons

TBAF - Fluoreto de Tetrabutilamônio

TBDMS - t-Butildimetilsilil

TBDMSCl - Cloreto de t-Butildimetilsilila

TCNE - Tetracianoetileno

TFD - Terapia Fotodinâmica

THF - Tetraidrofurano 


\section{Índice}

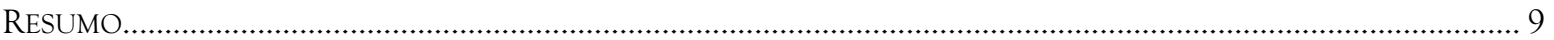

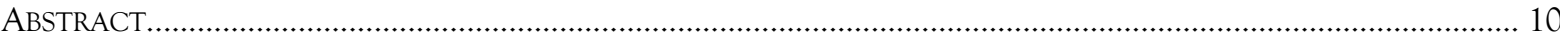

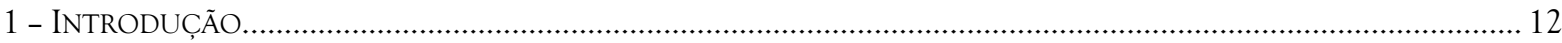

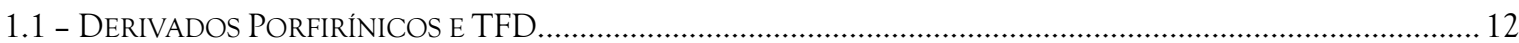

1.2 - Algumas Abordagens Sintéticas EXISTEnTES PARA OBTER DERIVAdos Porfirínicos.......................15

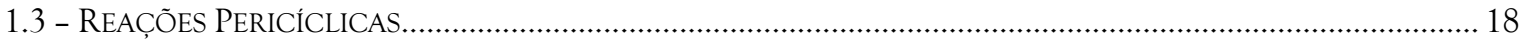

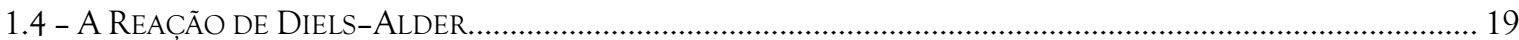

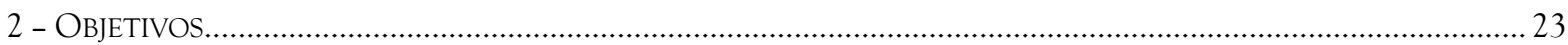

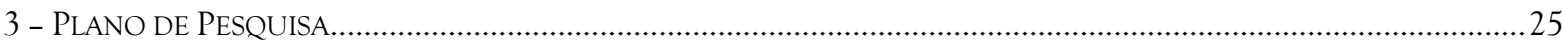

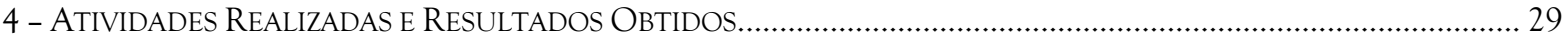

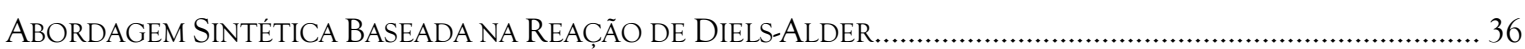

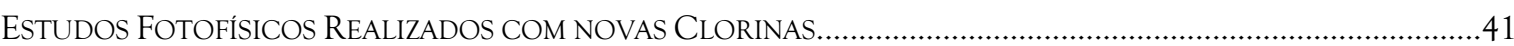

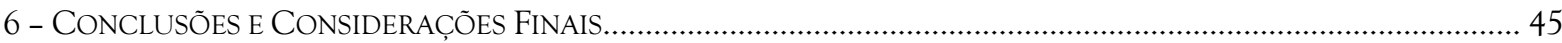

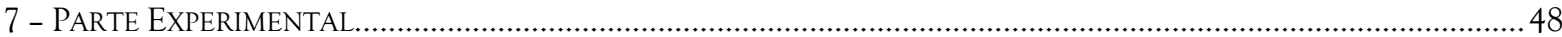

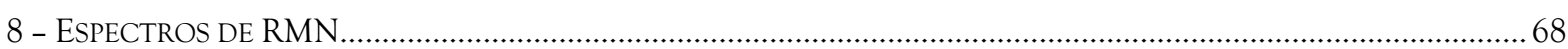

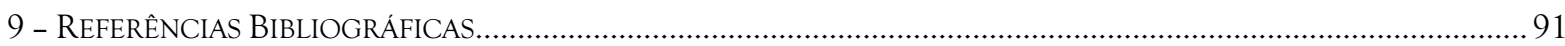




\section{Resumo}

Devido à sua intensa absorção de luz na região visível do espectro, as porfirinas e seus derivados (clorinas e bacterioclorinas) são de grande importância na terapia fotodinâmica (TFD) para o tratamento de doenças neoplásicas.

Neste trabalho foram sintetizadas as novas vinil-porfirinas estrategicamente funcionalizadas (47 e 48), seguida de uma sistemática de reações de Diels-Alder com dieófilos ativados, com o propósito de obter clorinas e/ou bacterioclorinas para potenciais aplicações em TFD.

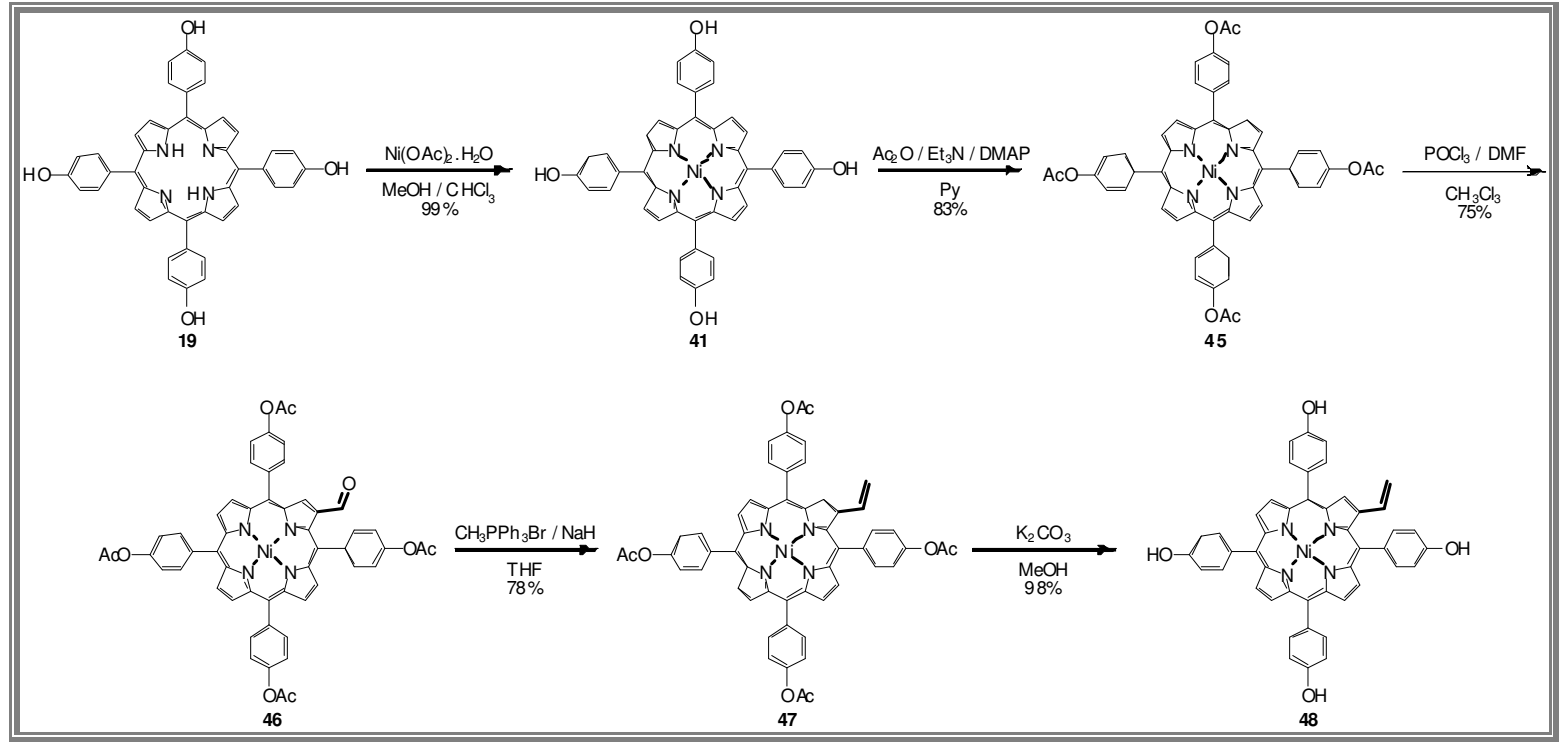




\section{Abstract}

Due to their strong absorption in the visible region, porphyrins and related derivatives (chlorins and bacteriochlorins) are very important in photodynamic therapy (PDT) for the treatment of neoplasic diseases.

In this work were synthesized the novel and strategically functionalizated vinylporphyrins 47 and 48, followed by systematic Diels-Alder reactions with activated dienophiles to obtain chlorins and/or bacteriochlorins, potentially useful on PDT.

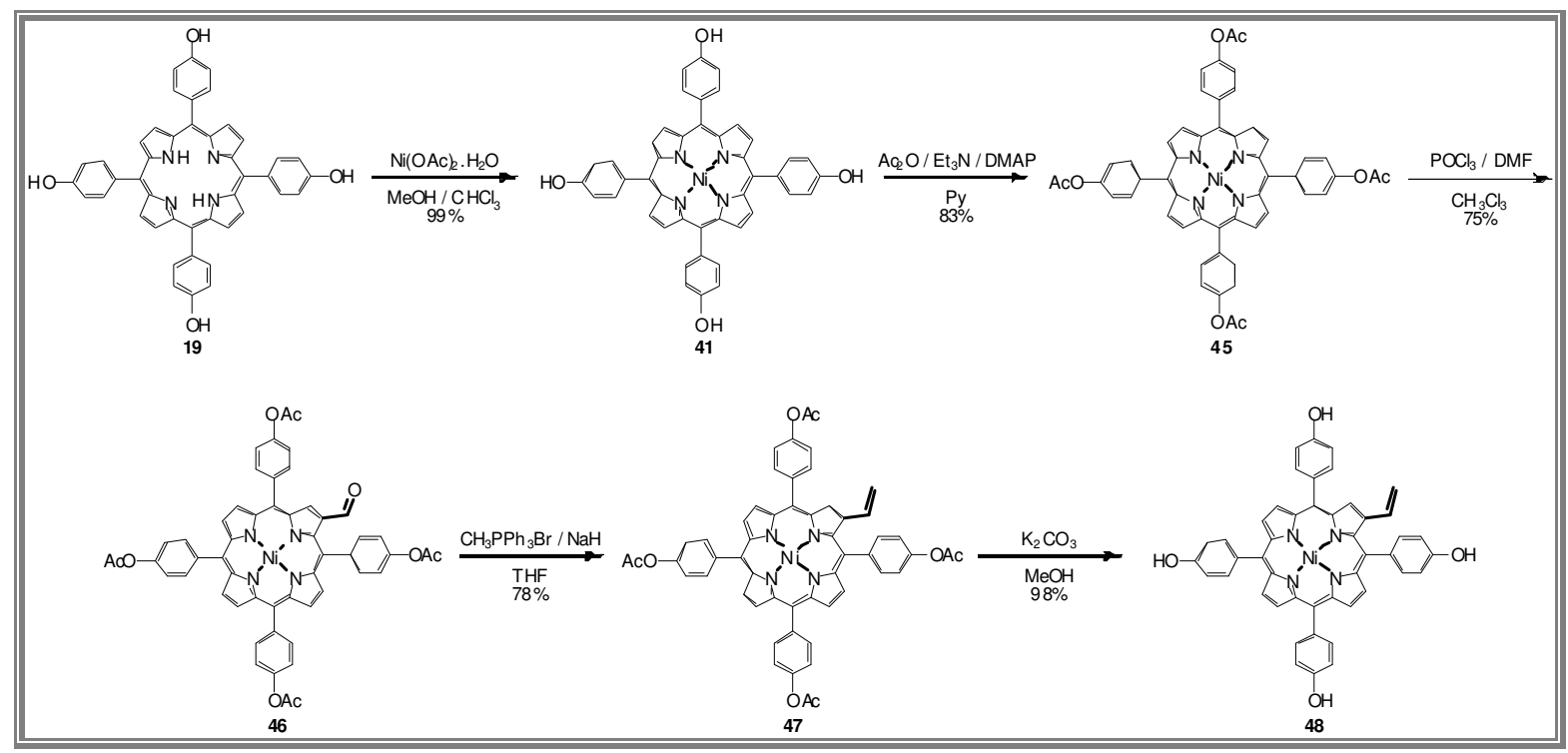




\section{Introdução}




\section{1 - Introdução}

\section{1 - Derivados Porfirinicos e TFD.}

Porfirinas (1) e seus derivados são substâncias macrocíclicas compostas de anéis pirrólicos interligados por quatro pontes de um átomo de carbono cada (pontes meso-metino). São substâncias que possuem uma extensa conjugação de ligações $\pi$, exibindo assim uma intensa coloração. Estes macrociclos constituem um sistema aromático com vinte e dois elétrons $\pi$ sendo necessários, no entanto, apenas dezoito para exibirem aromaticidade de acordo com a lei de Hückel $(4 n+2$ elétrons $\pi) .{ }^{1}$

Assim, quando a porfirina perde uma ligação dupla gera um novo macrociclo tetrapirrólico designado por clorina (2). Quando a porfirina perde duas ligações duplas toma a designação de bacterioclorina (3) se a perda ocorrer em anéis pirrólicos opostos, ou de isobacterioclorina (4) se a perda ocorrer em anéis pirrólicos adjacentes. Logo as clorinas, bacterioclorinas e isobacterioclorinas são, tal como as porfirinas, anéis aromáticos onde persistem os dezoito elétrons $\pi$ conjugados. ${ }^{2}$ (Figura 1).

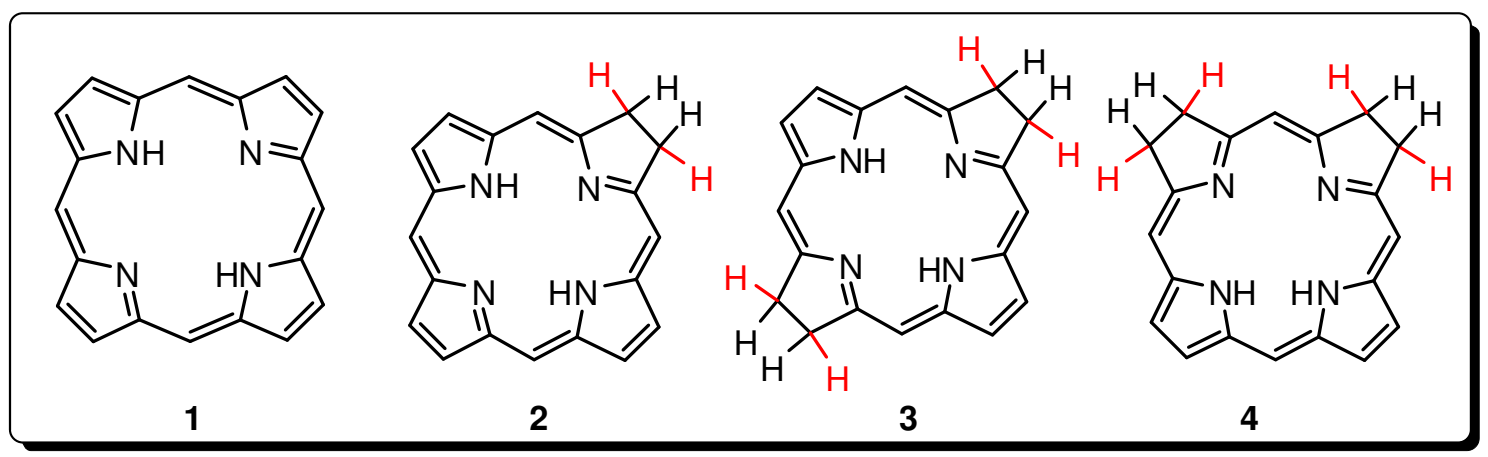

Figura 1: estruturas básicas de porfirinas (1), clorinas (2) e bacterioclorinas (3 e 4).

As porfirinas formam tipicamente sólidos cristalinos de cor púrpura. $\mathrm{O}$ espectro de absorção (Figura 2) apresenta uma banda de forte intensidade na região dos $400 \mathrm{~nm}$, designada por banda Soret, que é característica da deslocalização dos dezoito elétrons $\pi$ conjugados do macrociclo, o que significa que esta banda persiste nos macrociclos do tipo clorina, bacterioclorina e isobacterioclorina. Só quando o anel sofre abertura ou a conjugação é 
interrompida por qualquer outro motivo que a banda Soret desaparece. Na região dos 500-650 nm existe uma série de picos satélites de menor intensidade designados por bandas Q. A intensidade relativa desses picos varia de acordo com o número e a posição relativa dos grupos substituintes que se encontram nas posições periféricas do macrociclo. ${ }^{3}$

Analisando os espectros de absorção desses compostos podem-se destacar algumas particularidades destas substâncias do ponto de vista eletrônico e com isso evidenciar possíveis aplicações. Na Figura 2 são apresentadas as bandas de absorção características de alguns derivados porfirínicos.

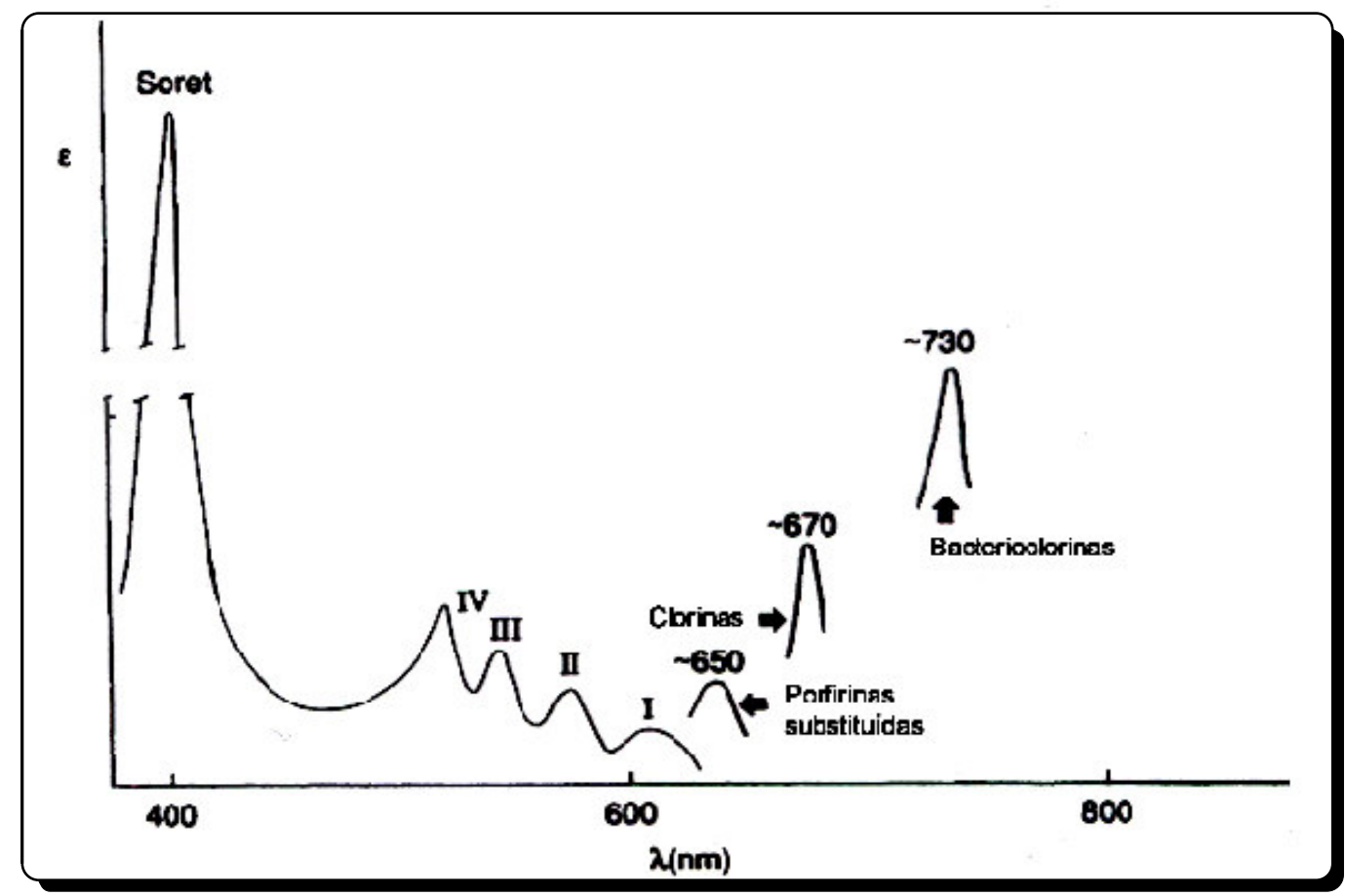

Figura 2: Espectros de UV-Vis de compostos tetrapirrólicos. ${ }^{3}$

O espectro de absorção das clorinas (Figura 2) mostra diferenças acentuadas relativamente ao das porfirinas, sendo a banda $Q$ na região dos $650 \mathrm{~nm}$ intensificada levando a diferenças na coloração destes compostos.

As clorinas geralmente formam sólidos escuros que quando dissolvidos dão origem a soluções verdes. As bacterioclorinas possuem uma banda de forte absorção na região dos 700 $750 \mathrm{~nm}$ e formam habitualmente soluções claras (esverdeadas) (Figura 2).

Os derivados porfirínicos possuem um caráter aromático bem pronunciado e, mesmo após a quebra de duplas ligações carbono-carbono (produção de clorinas e bacterioclorinas), os 
compostos permanecem com as mesmas características. Isso se deve a corrente aromática que permanece intacta após a quebra da conjugação. Como se pode ver na Figura 3, duas duplas ligações carbono-carbono possuem uma natureza química muito parecida com duplas ligações não aromáticas, o que também justifica a possibilidade de ocorrer reações nas posições $\beta$ - $\beta$ 'pirrólicas para a produção de clorinas, bacterioclorinas e demais derivados.

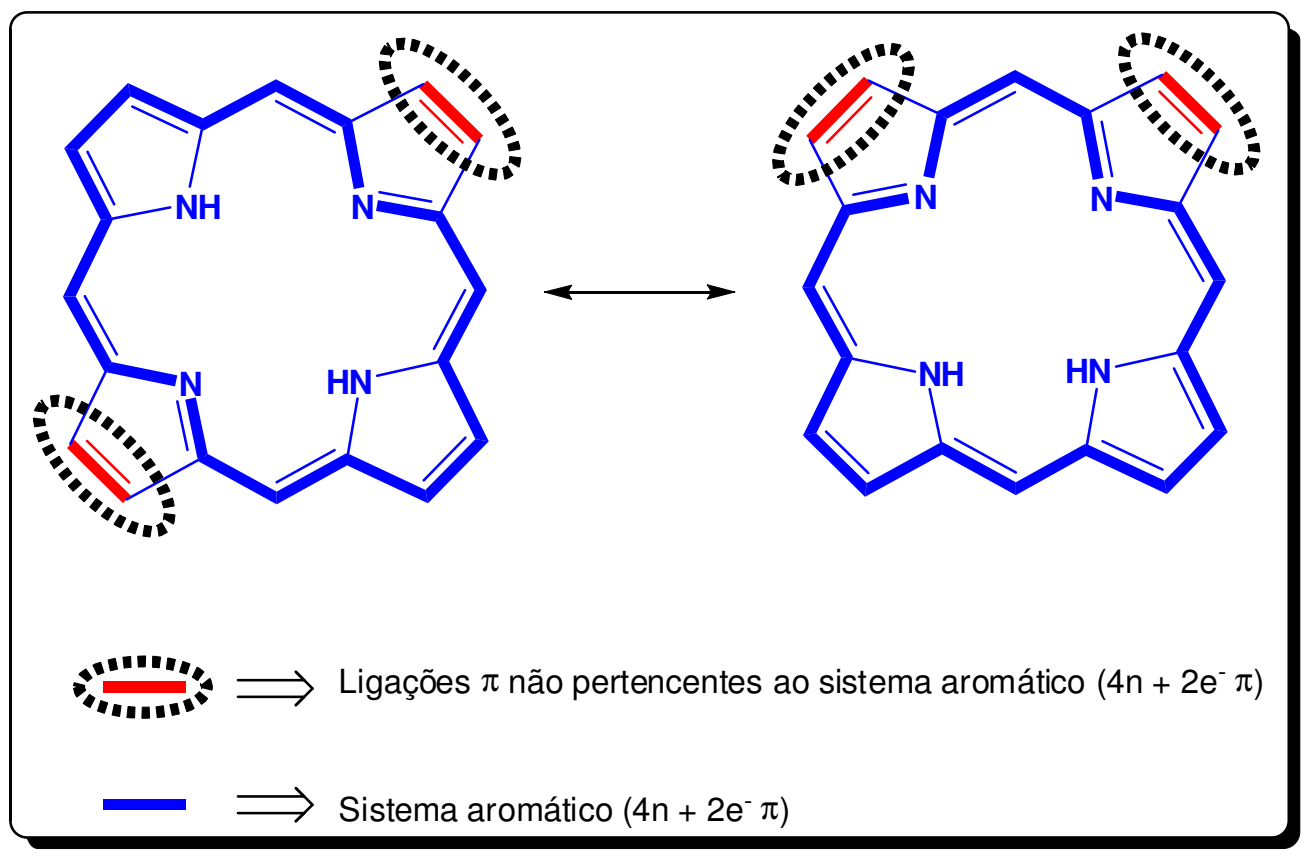

Figura 3: Ilustração das possíveis estruturas canônicas de ressonância de macrociclos porfirínicos.

Como pôde ser visto, as clorinas e bacterioclorinas possuem bandas de absorção mais intensas entre $650-750 \mathrm{~nm}$, isto é, na região do vermelho e infravermelho próximo no espectro eletromagnético. Em face disto, pode-se destacar uma importante aplicação para estas substâncias na produção de espécies químicas reativas, e consequentementemente sua apliacação direta na Terapia Fotodinâmica (TFD). ${ }^{4}$

Na Terapia Fotodinâmica é utilizada uma radiação que, ao ser absorvida por um cromóforo (endógeno ou exógeno), transfere essa energia para as suas redondezas. Essa transferência propicia a formação das espécies reativas de oxigênio (EROs) que induzem ao colapso celular. Dessa forma, a TFD tem se tornado importante pelo fato de ser uma técnica que utiliza radiação de baixa energia causando menos danos, como por exemplo, intervenções cirúrgicas, quimioterapia e radioterapia. 
A Figura 4 ilustra o grau de penetração da luz em um tecido tumoral com relação ao comprimento de onda da radiação incidente.

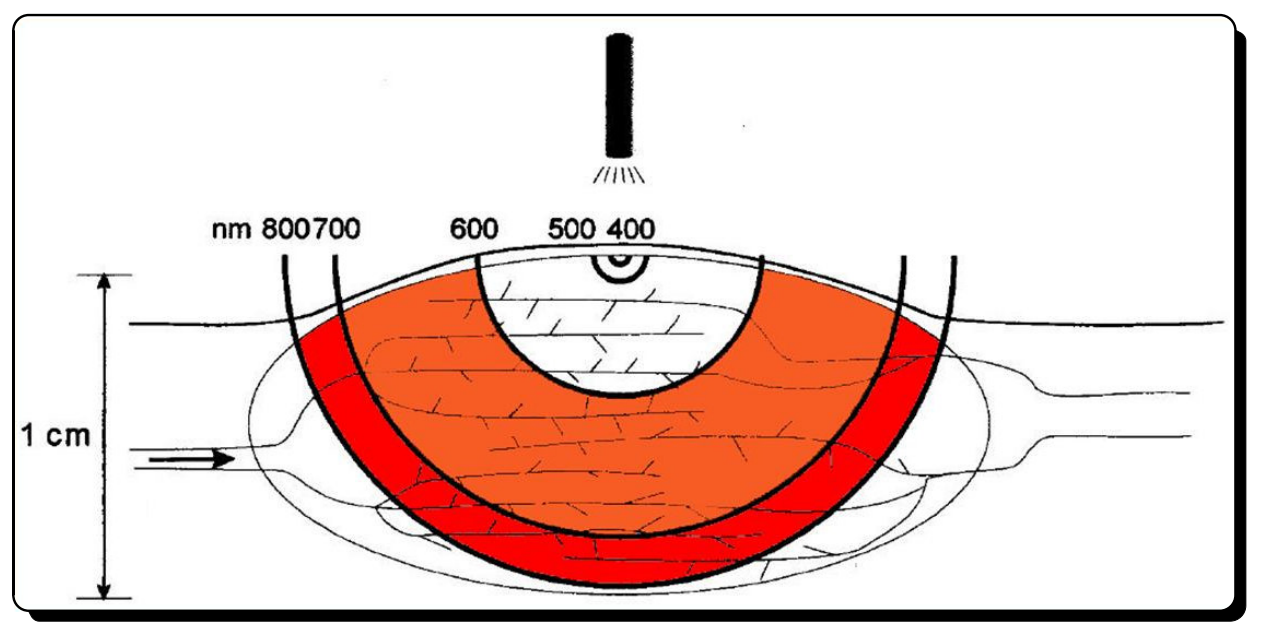

Figura 4: Dependência da penetração da luz com relação ao comprimento de onda. ${ }^{5}$

Assim sendo, as clorinas bem como os derivados do tipo 3 e 4 são de grande interesse para a utilização na Terapia Fotodinâmica, constituindo uma proposta alternativa para o tratamento de doenças tais como câncer e outras de natureza não neoplásicas. ${ }^{6}$

\section{2 - Algumas Abordagens Sintéticas Existentes para Obter Derivados Porfirinicos.}

Do ponto de vista sintético, a preparação de clorinas tem sido feita de diversas maneiras. ${ }^{5}$ Aproveitando o caráter não aromático de algumas duplas ligações, pode-se perfeitamente realizar uma oxidação branda com $\mathrm{OsO}_{4} / \mathrm{H}_{2} \mathrm{~S}$, produzindo inicialmente dióis que são transformados nos mais diversos produtos. $^{7}$ (Esquema 1)

\section{Esquema 1}
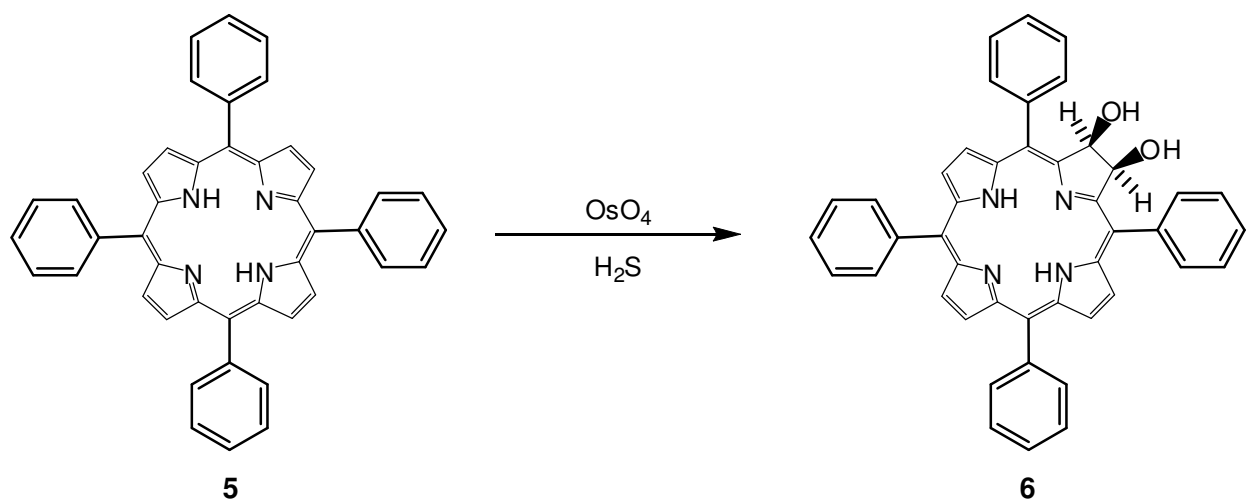
Outra possibilidade é reagir uma vinil-porfirina (no caso a protoporfirina IX dimetil éster 7) com oxigênio singlete, ${ }^{8}$ tendo como resultado a formação da clorina 8 conhecida como fotoprotoporfirina, que em seguida é convertida no aspartato 9 conhecido comercialmente como ATX-S10(Na). (Esquema 2)

\section{Esquema 2}
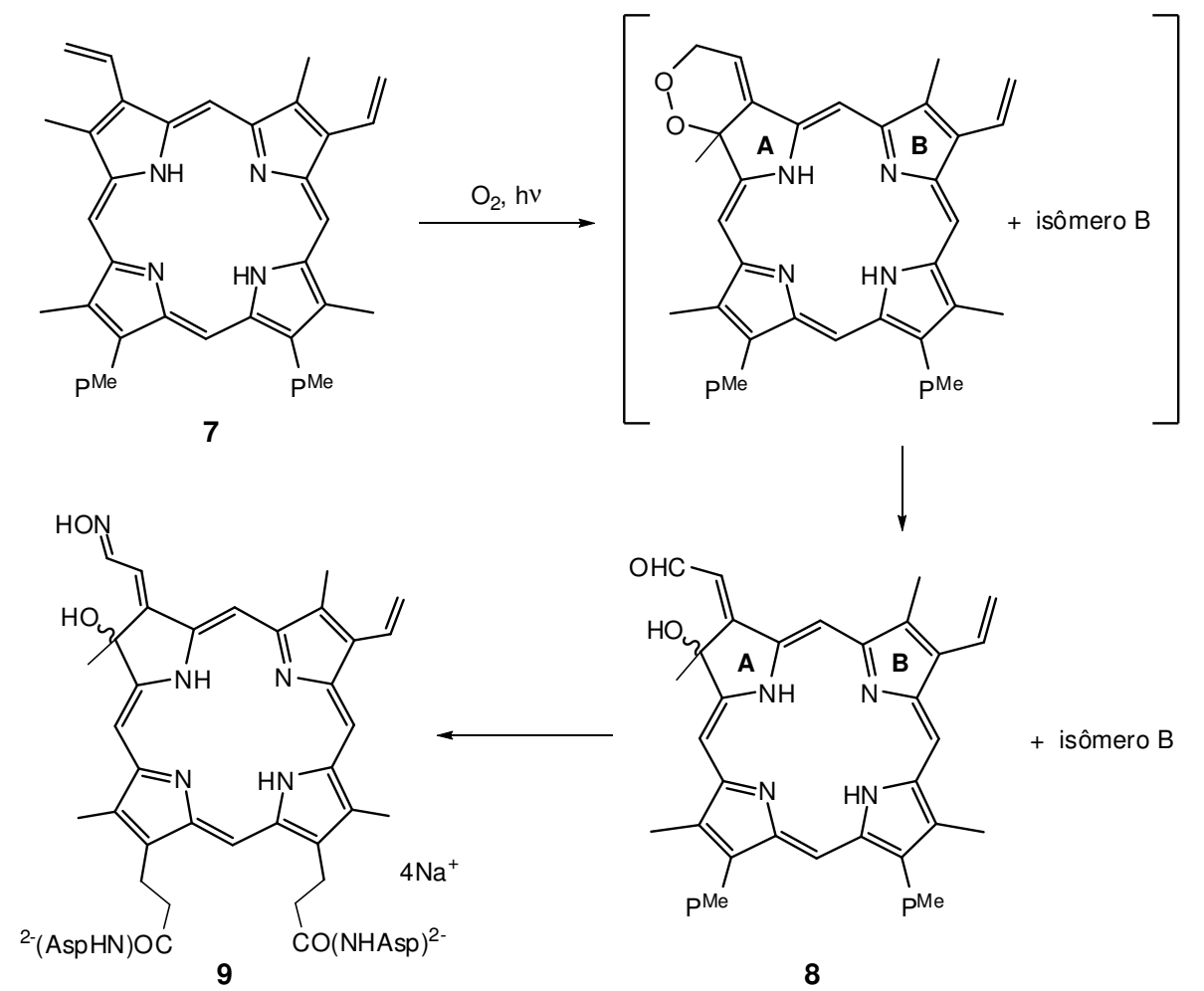

Um bom exemplo de reação direta é a redução de uma dupla ligação com diimida $[\mathrm{HN}=\mathrm{NH}]$ produzida in situ. ${ }^{9}$ A reação assim descrita por Whitlock e colaboradores ${ }^{9}$ forma uma mistura de clorina e bacterioclorina (a segunda podendo ser convertida na primeira por oxidação com o-cloranil). O exemplo a seguir (Esquema 3) mostra a forma que é preparado o renomado fármaco utilizado em TFD, conhecido como Foscan ${ }^{\circledR} 11,{ }^{10}$ em que sua preparação atende a metodologia acima descrita. 


\section{Esquema 3}

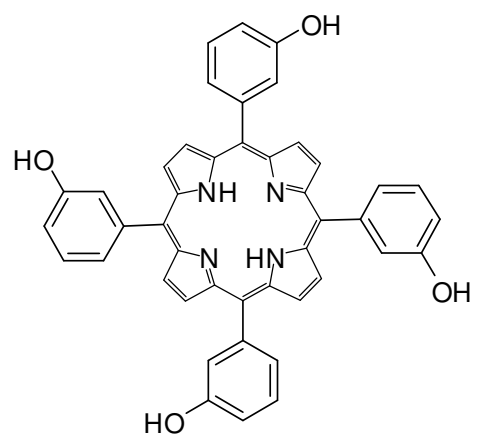

10

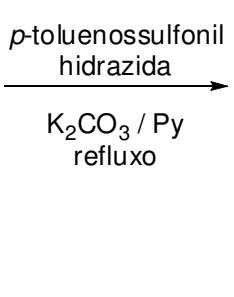

$\mathrm{K}_{2} \mathrm{CO}_{3} / \mathrm{Py}$
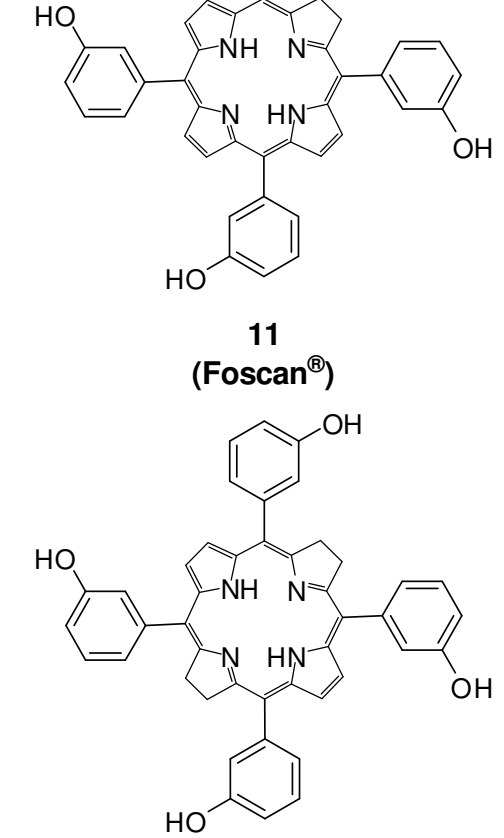

12

Neste tipo de reação, a diimida gerada in situ é oxidada a $\mathrm{N}_{2}$ após realizar a transferência dos dois átomos de hidrogênio para a dupla ligação carbono-carbono (conforme mecanismo do Esquema 4), o que nos casos acima descritos leva a formação das hidroporfirinas (clorinas e bacterioclorinas).

\section{Esquema 4}

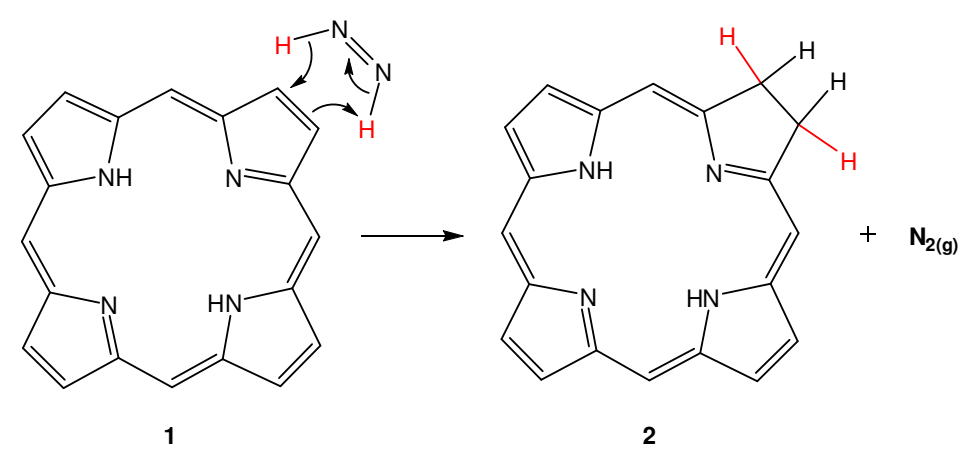

De forma análoga, a reação de Diels-Alder ${ }^{11}$ tem se mostrado como uma das alternativas simples para a obtenção de derivados do tipo clorina. Um dos aspectos que quimicamente chamam mais a atenção é a possibilidade de formar facilmente outros anéis ligados ao sistema porfirínico (conjugados ou não) e tudo em uma única etapa. Ainda, pode-se destacar que a 
reação de Diels-Alder pode ser considerada como uma das mais importantes reações químicas, dados os seus aspectos e particularidades estereoquímicas e à facilidade de formação de ligações carbono-carbono. ${ }^{12}$

No caso da síntese de clorinas, a reação de Diels-Alder é particularmente interessante, pois permite a migração da dupla ligação $\beta$ - $\beta$ '-pirrólica para o anel ciclohexeno externo, produzindo uma clorina e a formação de mais um anel carbocíclico ligado ao macrociclo tetrapirrólico, o que em alguns casos, permite funcionalizações estratégicas para uma maior atividade fotodinâmica dos compostos (Esquema 5).

\section{Esquema 5}

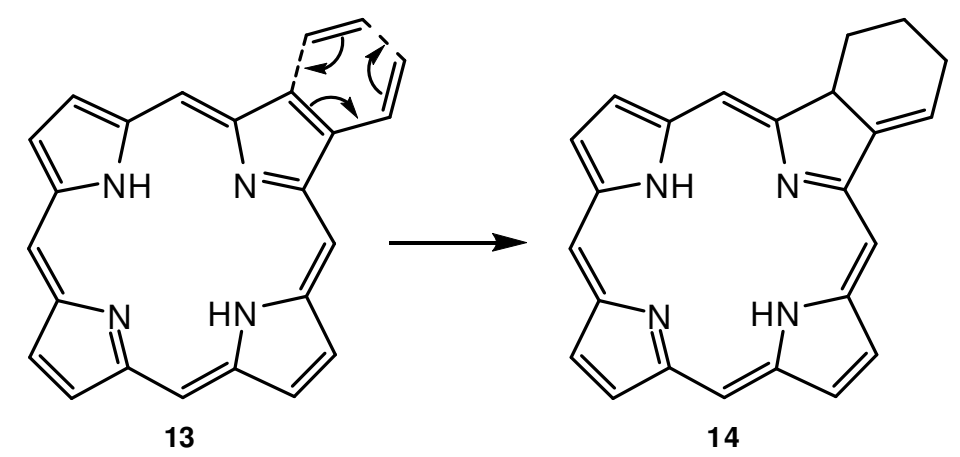

Existem inúmeros exemplos da aplicação de cicloadições para a produção de derivados porfirínicos, destacando-se principalmente o fármaco Visudyne ${ }^{\circledR}$, preparado pela abordagem sintética que envolve uma reação de Diels-Alder seguida de algumas modificações, produzindo benzoporfirinas. ${ }^{61}$

Portanto, partindo-se de vinil-porfirinas (dieno) e de alguns dienófilos ativados, é possível obter derivados porfirínicos com potencial aplicação na TFD com bons rendimentos, utilizando um processo viável e menos dispendioso conforme pode ser constatado em diversos trabalhos da literatura. ${ }^{5,6,13}$

\section{3 - Reações Pericíclicas.}

De acordo com a IUPAC, ${ }^{14}$ uma reação pericíclica é uma reação química em que ocorre uma reorganização concertada de ligações através de um arranjo cíclico de átomos continuamente interligados. Neste processo, a reação ocorre através de um estado de transição 
cíclico completamente conjugado e o número de átomos no arranjo cíclico é usualmente seis, podendo conter também outro número.

Os principais tipos de reações pericíclicas são: Reações Eletrocíclicas, Reações de Cicloadição, Reações de Rearranjo Sigmatrópico, Reações Queletrópicas e as Reações do tipo "Ene". $\mathrm{Na}$ figura a seguir serão mostrados alguns exemplos destas reações. ${ }^{15}$

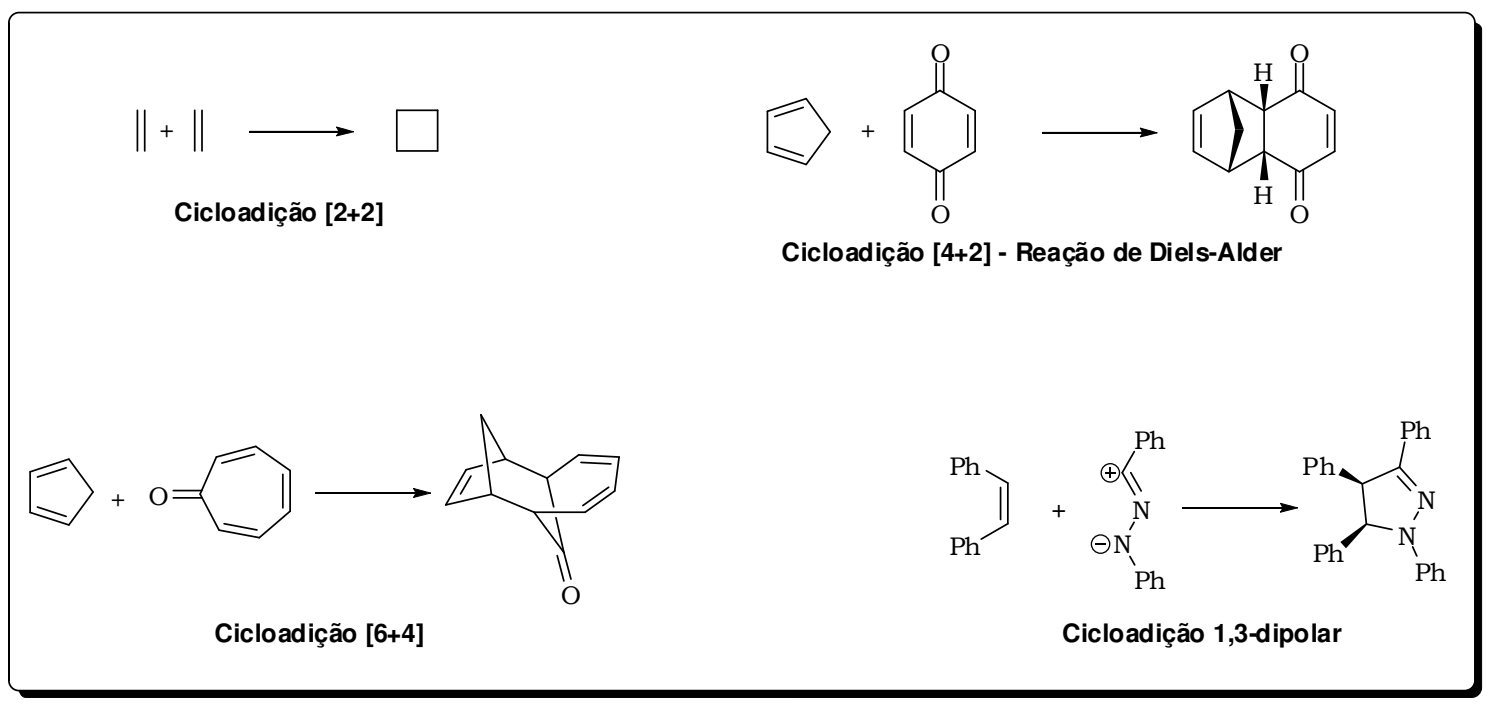

Figura 5: Exemplos de Reações de Cicloadição.

Evidentemente que neste texto será dada uma atenção especial às reações de cicloadição, particularmente a de Diels-Alder.

\section{4 - A Reação de Diels-Alder. ${ }^{16}$}

Desde sua descoberta em $1928^{11}$ por Otto Diels e seu estudante Kurt Alder, a reação de Diels-Alder vem se destacando como uma das reações mais empregadas na síntese orgânica. ${ }^{i}$ Esta reação reúne características de grande valor para química sintética, como o fato de ser essencialmente estereoseletiva e de possibilitar, nas suas versões inter-molecular e intramolecular, a síntese de estruturas de grande complexidade. Um outro aspecto marcante da reação de Diels-Alder é a questão da "economia de átomos", ou seja, durante o processo reacional, independente da natureza da reação (inter ou intra-molecular), não há perda de

\footnotetext{
${ }^{i}$ Desde sua descoberta foram publicados mais de 30.800 trabalhos envolvendo o termo "Diels-Alder". Somente nos últimos dois anos (2006-2007) foram publicados 1.962 trabalhos, o que equivale a quase 3 trabalhos por dia. Fonte: SciFinder Scholar 2006.
} 
átomos ou de grupos funcionais. Em sua publicação original, os autores Diels e Alder pareciam prever a revolução que seus estudos trariam para a química sintética, tanto que afirmaram com propriedade: 17 "... Our results will play a role only in the discussion of theoretically interesting questions, for example, the relationships of strain in policiclic systems, but probably also will yield greater significance in a practical sense. Thus it appears to us that the possibility of synthesis of complex compounds related to or identical with natural products such as terpenes, sesquiterpenes, perhaps even alkaloids, has been moved to the near prospect..."

A primeira reação publicada pelos seus descobridores envolvia dois compostos relativamente simples, o ciclopentadieno (15) e a benzoquinona (16). Segundo os autores, foram isolados dois produtos: o aduto 17 e o bis-aduto 18 .

\section{Esquema 6}

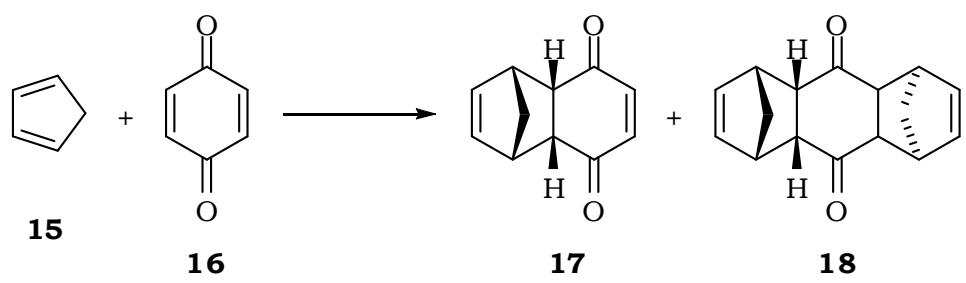

Os compostos que participam da reação de Diels-Alder, normalmente são chamados de dieno e dienófilo; a espécie que contribui com dois pares de elétrons $\pi$ durante a reação é o dieno e a que participa com apenas um par de elétrons $\pi$ o dienófilo.

Um ponto contraditório e até surpreendente é o grande intervalo entre o comunicado da existência da reação de Diels-Alder e a primeira síntese total envolvendo uma reação deste tipo (1951). ${ }^{18}$ Alguns autores modernos atribuem este intervalo de tempo ao caráter da própria pesquisa realizada por Diels e por Alder e ao empenho destes autores em estudar a reação em mais detalhes para então dominar suas características e particularidades. Isto fica bastante evidente quando alguns anos depois da publicação original, Alder publica uma seqüência de trabalhos experimentais que fundamentavam o que hoje conhecemos como "Regra de Alder" ou Regra de Adição "endo". ${ }^{19}$ Outro motivo a ser destacado é o contexto político e científico vivido na Alemanha nas décadas de 1930 e 1940. Seguramente esta "lacuna" tem origens no atraso imposto pelo regime político da época. Há uma frase dita pelos próprios autores Diels e Alder que mostra bem o interesse em não perderem a autoridade com relação à reação que descobriram. ${ }^{17}$...."We explicit reserve for ourselves the application of the reaction developed by us to the solution of such problems"... 
Um momento inevitável de divulgação e reconhecimento dos trabalhos de Diels e Alder foi a indicação e a conquista do Prêmio Nobel em 1950. A partir deste ano começaram a aparecer muitos trabalhos envolvendo não somente a reação de Diels-Alder, mas reações pericíclicas em geral.

É preciso encerrar por aqui esta seção sobre a reação de Diels-Alder para não tornar este texto por demais cansativo. De fato, muitos aspectos da reação de Diels-Alder não foram abordados, e desta maneira, é preciso reafirmar o caráter ilustrativo desta seção da dissertação. Pode-se concluir que a reação de Diels-Alder agrega características muito especiais, e, portanto, é impossível realizar uma revisão ampla sobre o assunto que ocupe tão poucas páginas. 


\section{Objetivos}




\section{2 - Objetivos}

A procura de fotossensibilizadores mais efetivos vêm sendo um dos objetivos de investigação de nosso grupo de pesquisa e atualmente vêm rendendo resultados muito promissores. ${ }^{20}$ Tais estudos têm sido de vital importância para o desenvolvimento de novas metodologias aspirando à obtenção de compostos mais eficazes para o tratamento de doenças como o câncer, psoríasis, ateromas, infecções bacterianas e virais e também em AMD (Agerelated Macular Degeneration)., 


\section{Plano de Pesquisa}




\section{3 - Plano de Pesquisa}

Neste projeto, planejou-se realizar a adição de um grupo vinilo nas porfirinas comerciais 19, 20 e 21 utilizando o procedimento no qual, através da formilação de Vilsmeier-Haack ( $\left.\mathrm{POCl}_{3} / \mathrm{DMF}\right)$, seguida da reação de Wittig $\left(\mathrm{CH}_{3} \mathrm{PPh}_{3} \mathrm{Br} / \mathrm{Base} / \mathrm{THF}\right),{ }^{21}$ pudessem ser obtidos os produtos 22, 23 e 24, mostrados no Esquema 7.

\section{Esquema 7}

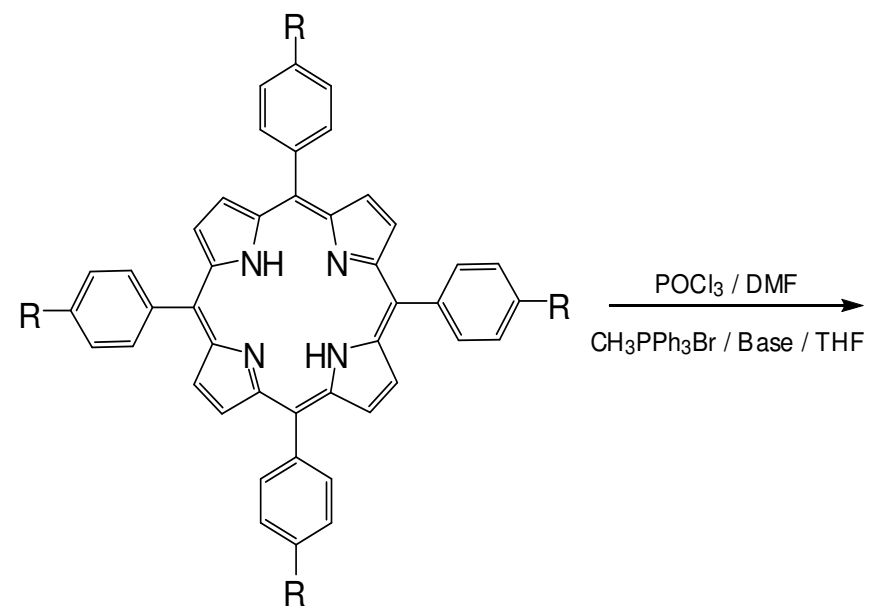

$19 \mathrm{R}=\mathrm{OH}$

$20 \mathrm{R}=\mathrm{NH}_{2}$

$21 \mathrm{R}=\mathrm{F}$

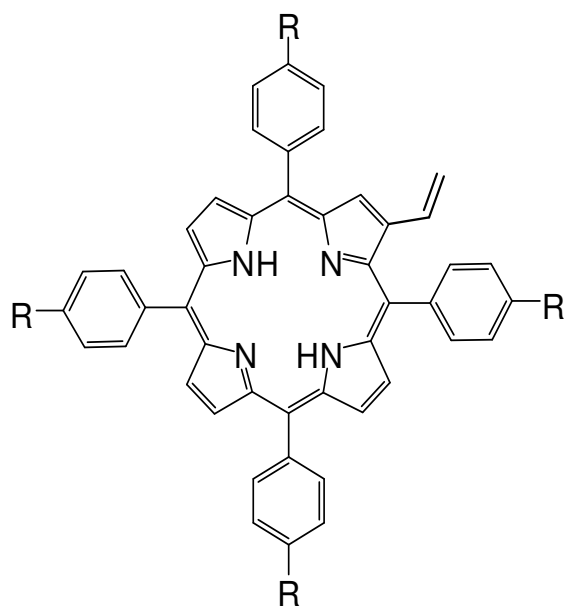

$22 \mathrm{R}=\mathrm{OH}$

$23 \mathrm{R}=\mathrm{NH}_{2}$

$24 \mathrm{R}=\mathrm{F}$

Ao obter as porfirinas estrategicamente funcionalizadas, estas seriam submetidas a reações de Diels-Alder com dienófilos ativados como tetraciano-etileno (TCNE) (25), dimetilacetilenodicarboxilato (DMAD) (26), ${ }^{13 \mathrm{~d}}$ anidrido maleico (27) e tetraciano-1,4-benzoquinona (28). (Esquema 8)

\section{Esquema 8}<smiles>N#CC(C#N)=C(C#N)C#N</smiles>

25<smiles>COC#CCOC</smiles>

26<smiles>O=C1C=CC(=O)O1</smiles>

27<smiles>N#CC1=C(C#N)C(=O)C(C=N)=C(N)C1=O</smiles>

28 
Modificações estruturais promovidas pela reação de Diels-Alder já foram estudadas por Cavaleiro et $a l^{13 \mathrm{~h}}$ utilizando algumas porfirinas relativamente simples como 29 e 30, obtendo os cicloadutos 33-36 (Esquema 9). Entretanto, nenhum destes derivados foi estrategicamente planejado para o estudo quanto às aplicações como fotossensibilizadores. Neste caso, foi estudado apenas o comportamento e a reatividade das duas porfirinas 29 e 30 como dieno, sem que fossem investigadas as preparações de vinil-porfirinas devidamente substituídas com grupos hidrofílicos ou farmacofóricos, o que viabilizaria estudos de aplicações em TFD. Sendo assim, o objetivo principal deste projeto consiste em estender a metodologia para outros sistemas porfirínicos que mais tarde permitam modificações essenciais aos estudos fotofísicos e fotobiológicos.

\section{Esquema 9}
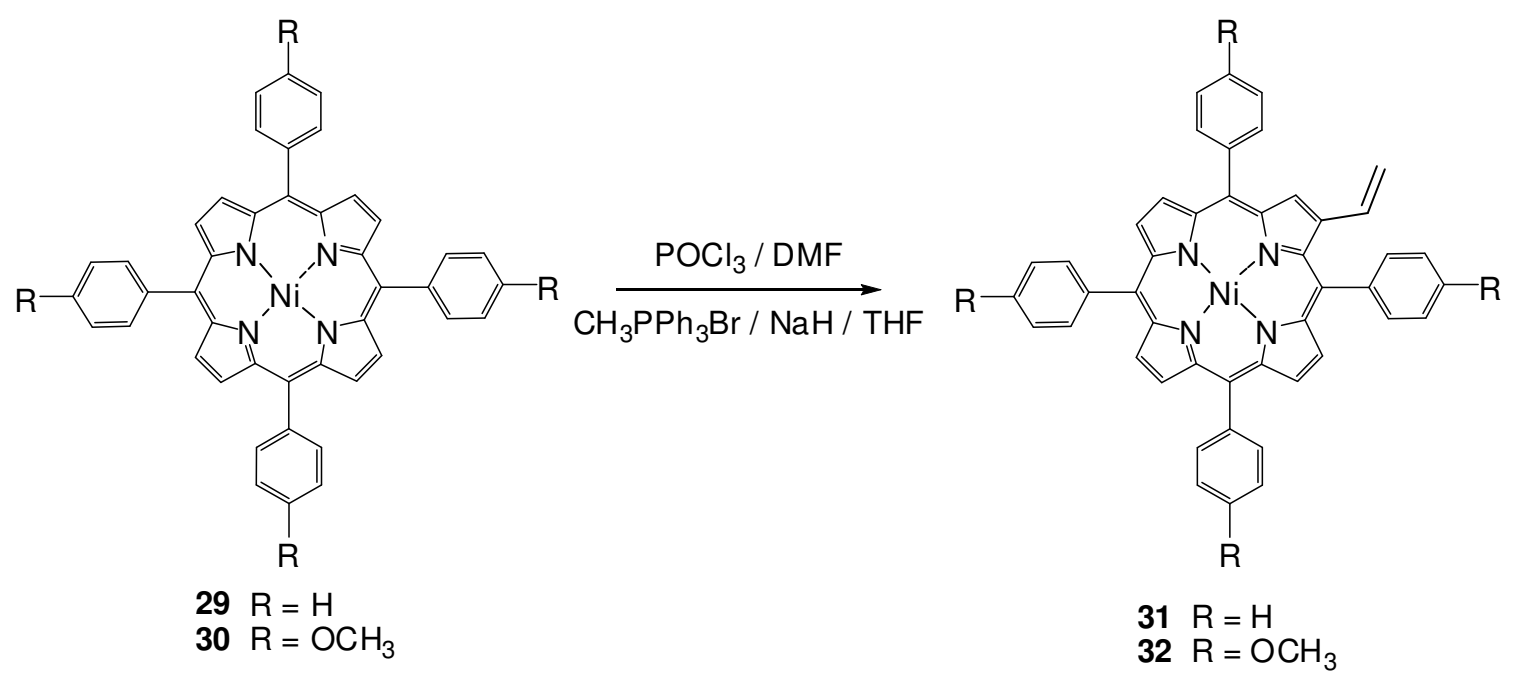

$\begin{aligned} \mathrm{R} & =\mathrm{H} \\ \mathbf{R} & =\mathrm{OCH}_{3}\end{aligned}$

$31 \mathrm{R}=\mathrm{H}$

$32 \mathrm{R}=\mathrm{OCH}_{3}$

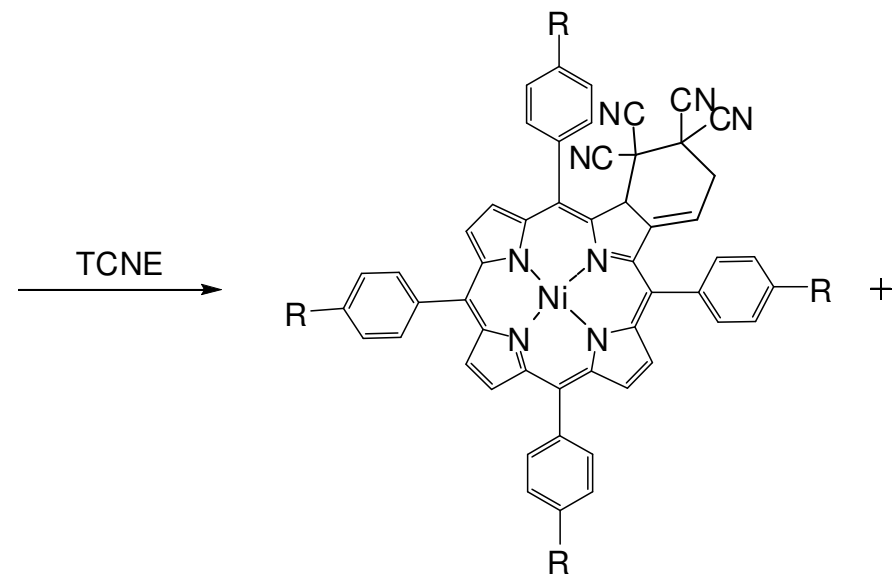

$33 \mathrm{R}=\mathrm{H}$

$34 \mathrm{R}=\mathrm{OCH}_{3}$

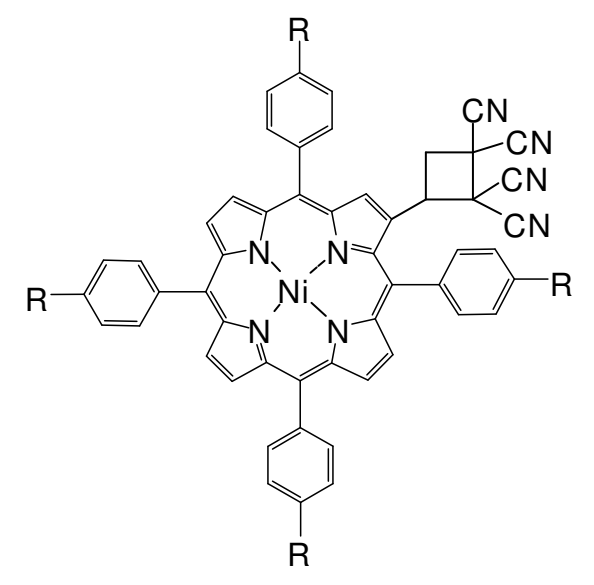

$35 \mathrm{R}=\mathrm{H}$

$36 \mathrm{R}=\mathrm{OCH}_{3}$ 
Uma vez obtidas as respectivas porfirinas 22, 23 e 24 (Esquema 7)e então estudadas suas reatividades nas reações de Diels-Alder seriam realizados alguns testes de solubilidade desses compostos em água. Caso a solubilidade se mostrasse muito baixa, uma alternativa proposta seria preparar derivados glicoporfirínicos, ${ }^{22}$ ou mesmo anexar alguns outros grupos farmacofóricos. 


\section{Atividades Realizadas e Resultados Obtidos}




\section{4 - Atividades Realizadas e Resultados Obtidos}

Conforme mencionado anteriormente, a primeira etapa deste projeto envolve a formilação em uma posição $\beta$-pirrólica de porfirinas utilizando o reagente de Vilsmeier $\left(\mathrm{POCl}_{3} / \mathrm{DMF}\right){ }^{23}$

Em geral, para realizar formilações via reação de Vilsmeier em porfirinas, a "proteção" dos nitrogênios tetrapirrólicos (metalação) se faz necessária ${ }^{24}$ para que possam ser obtidos melhores rendimentos, bem como tornar a reação quimioseletiva, ou seja, neste caso direcionar a reação para as posições $\beta$-pirrólicas do macrociclo porfirínico.

Dessa forma, decidiu-se a partir de alguns bons exemplos com porfirinas similares, ${ }^{13 \mathrm{~d} f, 21}$ preparar porfirinatos de $\mathrm{Ni}^{2+}$. $\mathrm{O}$ método geral de preparação de porfirinatos de níquel é a partir do acetato desse metal, obtido pela neutralização de $\mathrm{NiCO}_{3}$ com ácido acético glacial, o que forneceu o $\mathrm{Ni}(\mathrm{OAc})_{2} \cdot \mathrm{H}_{2} \mathrm{O}$ em rendimento de $96 \%$.

Sabendo que haveria uma limitada disponibilidade das porfirinas 19, 20 e 21, foi decidido criar um protocolo experimental partindo da p-tetrametóxifenilporfirina 37, já conhecida quanto às modificações estruturais desejadas, como também por ser um material disponível em quantidades apreciáveis no laboratório.

Inicialmente reagiu-se $37 \mathrm{com} \mathrm{Ni}(\mathrm{OAc})_{2} \cdot \mathrm{H}_{2} \mathrm{O}$ utilizando o método em meio ácido ${ }^{25}$ $\left(\mathrm{AcOH} / \mathrm{CHCl}_{3}\right.$ ), o que forneceu a metaloporfirina $38 \mathrm{com}$ um rendimento de 93\% (Esquema 10).

\section{Esquema 10}

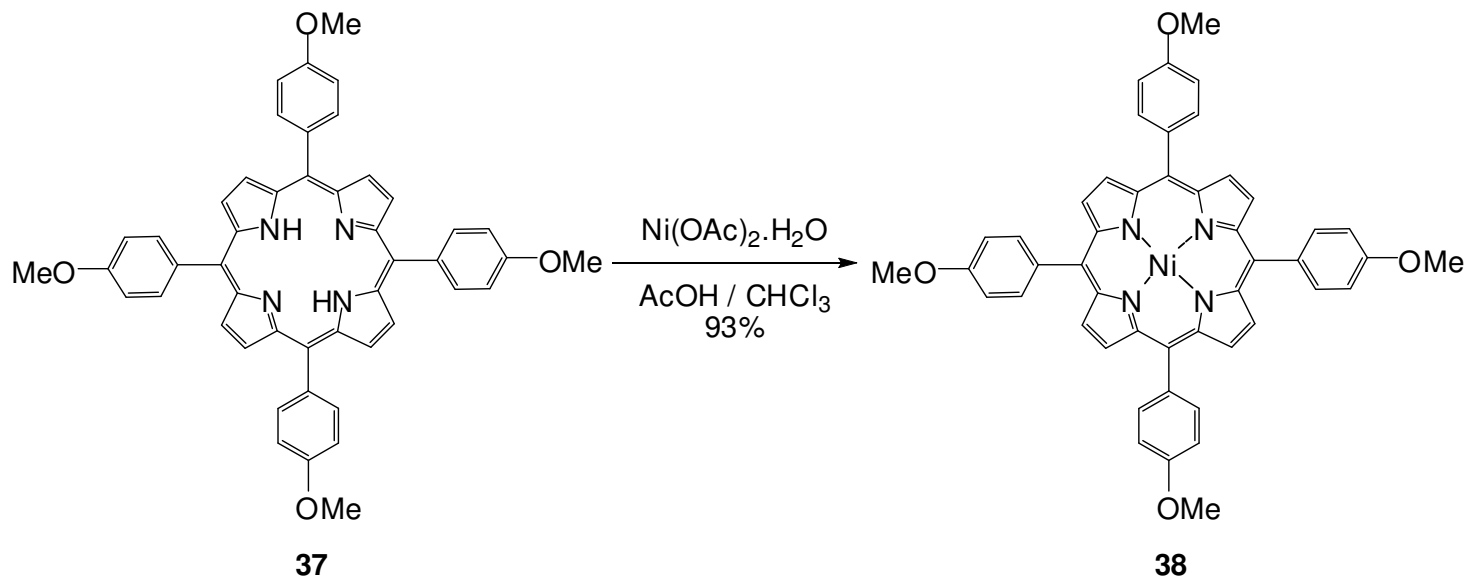


Em seguida, foram realizadas reações teste com o reagente de Vilsmeier, ${ }^{26}$ das quais o procedimento de Mironov e colaboradores ${ }^{27}$ foi o que rendeu melhores resultados (47\%) para a obtenção da formilporfirina 39 (Esquema 11). Rendimentos moderados em reações de formilação envolvendo a porfirina 38 já foram relatados ${ }^{27}$ e muito provavelmente são devido às ativações de outras posições dos sistemas aril-porfirínicos, o que significa a ocorrência de muitas reações laterais.

\section{Esquema 11}

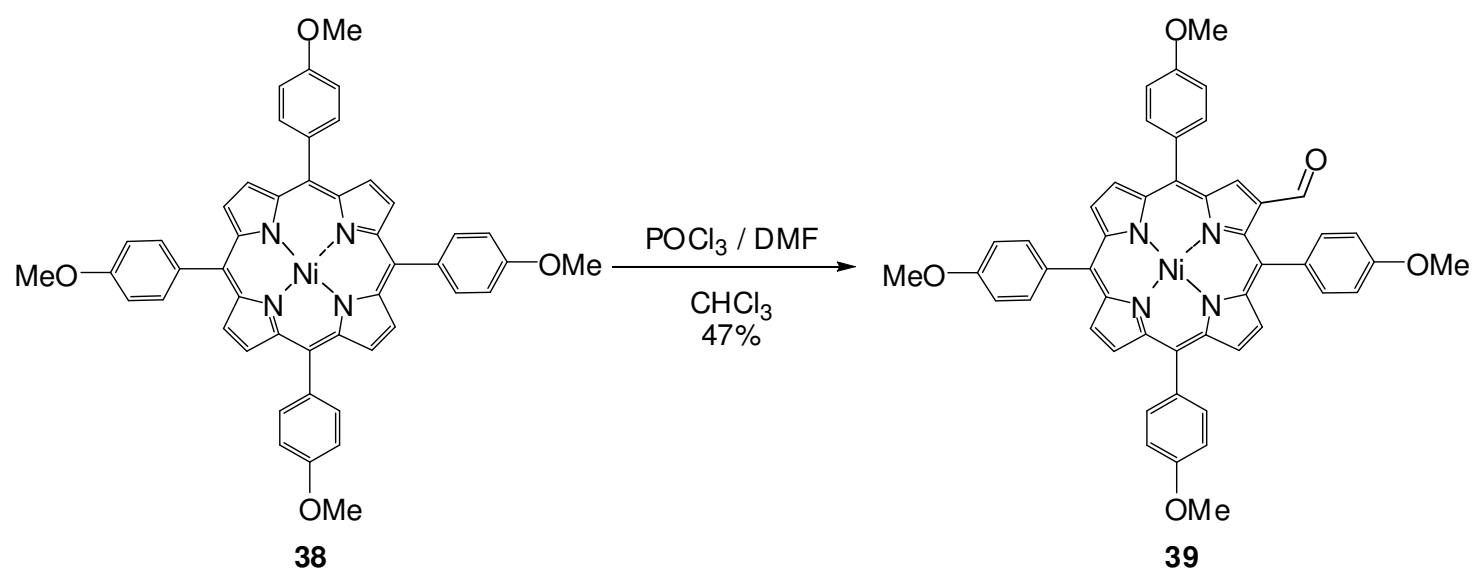

A próxima etapa dentro das estratégias propostas era obter a vinil-porfirina 40 (Esquema 12) por meio de uma reação de Wittig, utilizando $\mathrm{CH}_{3} \mathrm{PPh}_{3} \mathrm{Br} / \mathrm{Base} / \mathrm{THF}{ }^{21}$ Alguns testes preliminares utilizando $\mathrm{NaH} 95 \%$ como base forneceram o composto 40 , conforme esperado (35\% de rendimento).

\section{Esquema 12}

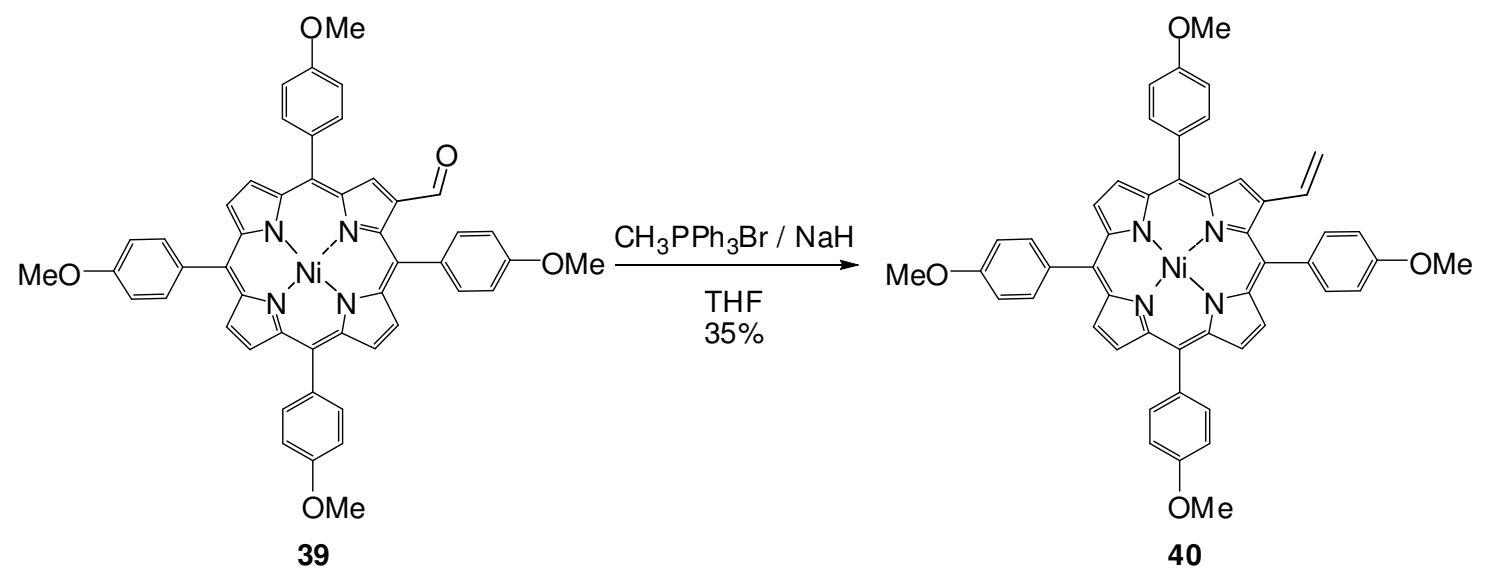

Após testadas as condições reacionais adequadas, resolveu-se dar continuidade aos estudos deste trabalho com as porfirinas propostas inicialmente. 
Sendo assim, o complexo 41 foi preparado pela reação de 19 com $\mathrm{Ni}(\mathrm{OAc})_{2} \cdot \mathrm{H}_{2} \mathrm{O}$ em $\mathrm{CHCl}_{3} / \mathrm{MeOH}^{28}$ a refluxo por 2 dias, obtendo a $p$-NiTPP(OH) ${ }_{4}(41)$ com um rendimento de 99\%. (Esquema 13).

\section{Esquema 13}

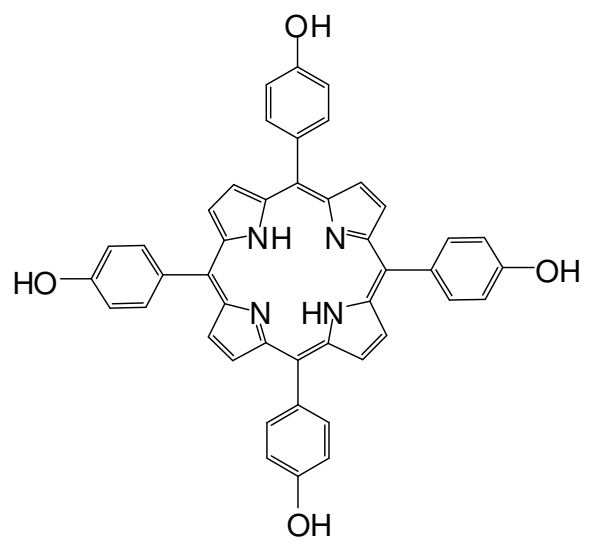

19

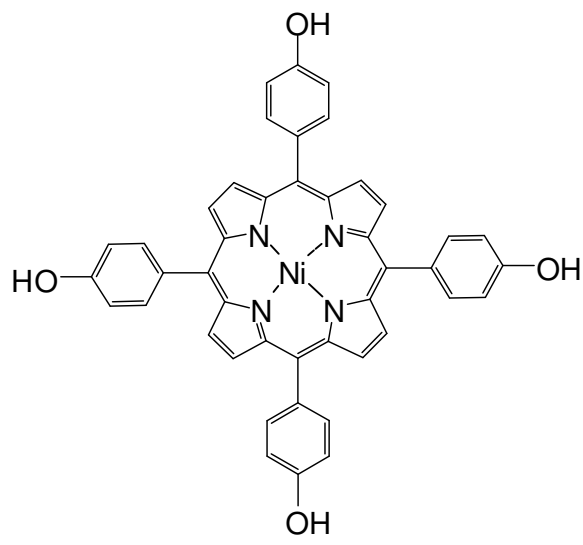

41

Em seguida, o composto 41 foi tratado com o reagente de Vilsmeier (Esquema 14) nas condições experimentais estabelecidas anteriormente. ${ }^{23}$ Entretanto, o resultado deste primeiro teste não foi como o esperado, visto que foi obtida uma mistura complexa de produtos de difícil separação. Ainda assim, realizou-se uma análise de $\mathrm{RMN}$ de ${ }^{1} \mathrm{H}$ do produto bruto de onde não foi possível identificar a presença do composto 42 .

\section{Esquema 14}
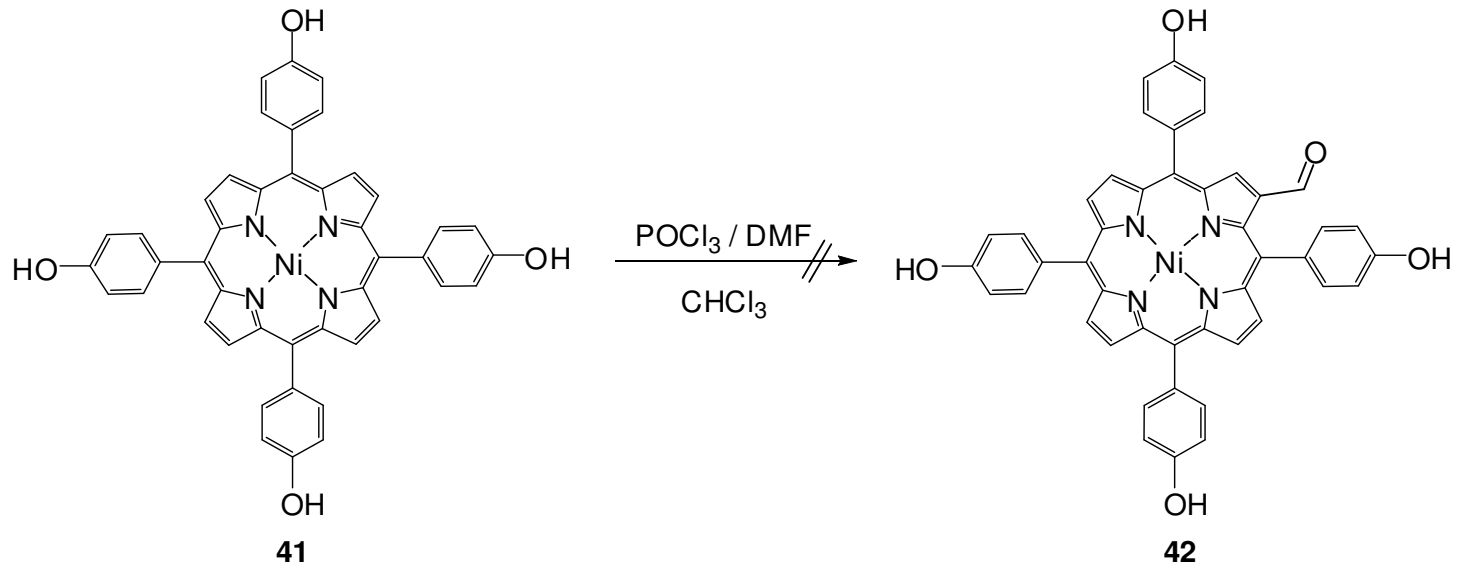

Neste ponto acreditava-se que poderiam estar acontecendo reações entre os grupos hidroxil de 41 e o reagente de Vilsmeier, formando assim ésteres de fósforo. Para contornar esta provável dificuldade, foram propostos alguns grupos protetores. 
Uma reação de proteção de grupos hidroxila muito difundida em síntese orgânica e de fácil remoção em etapas posteriores é a formação de um éter de silício a partir do TBDMSCl (cloreto de t-butildimetilsilano), resistente a vários meios reacionais. Da reação de um álcool/fenol com TBDMSCl/imidazol/THF ${ }^{29}$ ocorre a proteção do oxigênio com certa facilidade (altos rendimentos), sendo retirado esse grupamento na presença de TBAF (fluoreto de tetrabutil-amônio).(Esquema 15)

\section{Esquema 15}
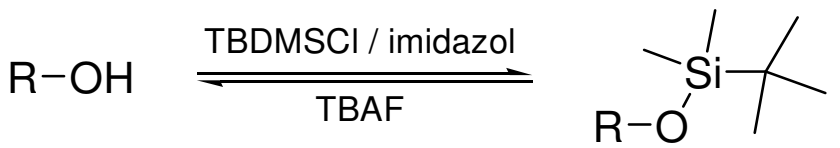

No entanto, verificou-se ao realizar uma pesquisa na literatura, ${ }^{30,31}$ que nas condições em que é realizada a formilação, o grupo protetor silano é retirado, ocorrendo a hidroformilação nos átomos de oxigênio protegidos com TBDMS. No mesmo exemplo apresentado (transformações de açúcares) ${ }^{30}$ verificou-se que o grupo acetil permanecia intacto após reação com o reagente de Vilsmeier (Esquema 16), dando uma forte evidência de que este seria um ótimo protetor para o composto 41.

\section{Esquema 16}

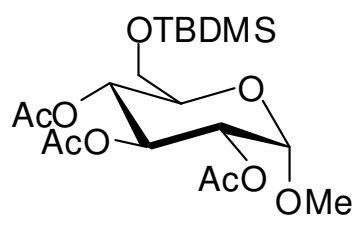

43

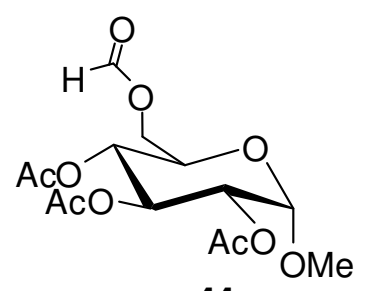

44

Sendo assim, a reação de $41 \mathrm{com} \mathrm{Ac}_{2} \mathrm{O} / \mathrm{Et}_{3} \mathrm{~N} / \mathrm{DMAP} / \mathrm{Py}^{32}$ (Esquema 17) em atmosfera inerte foi realizada com sucesso, obtendo o composto protegido $45 \mathrm{com}$ um rendimento de $83 \%$. 


\section{Esquema 17}

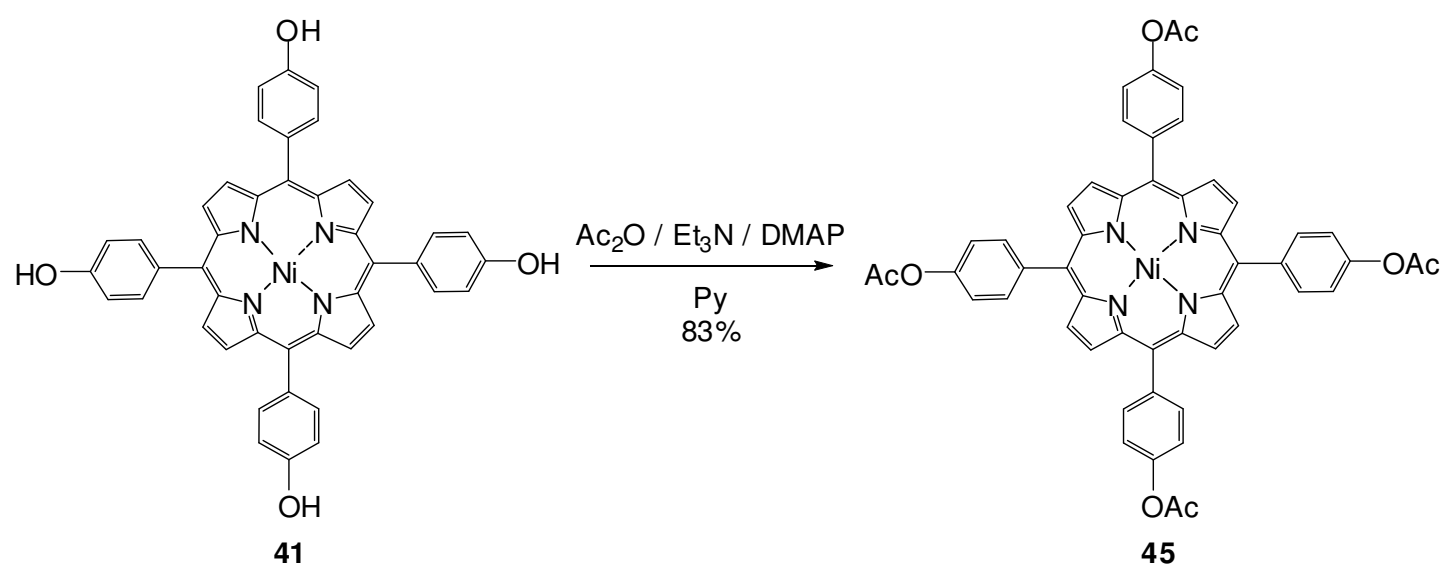

Em seguida, foi feita a formilação de 45 utilizando o complexo de $\mathrm{POCl}_{3} / \mathrm{DMF}$ em $\mathrm{CHCl}_{3}$ nas condições de Mironov, ${ }^{27}$ obtendo o produto $46 \mathrm{em}$ bom rendimento (75\%) (Esquema 18).

\section{Esquema 18}

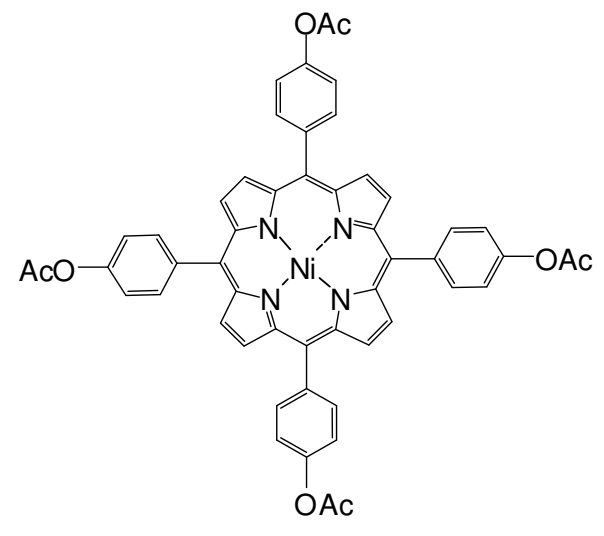

45

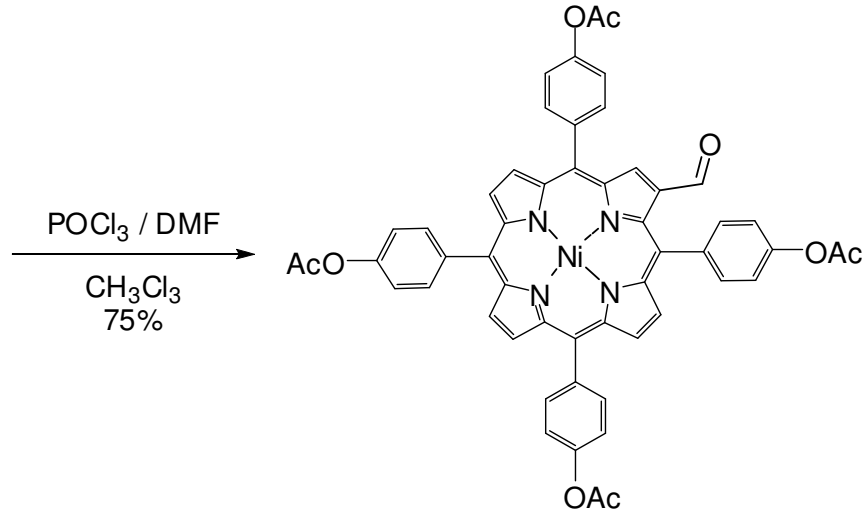

46

Para a preparação do derivado vinílico 47 (via reação de Wittig) também foram encontrados alguns problemas quanto ao tempo de reação entre o aldeído 46 e o ileto metílico de fósforo $\left(\mathrm{Ph}_{3} \mathrm{P}=\mathrm{CH}_{2}\right)$. Neste caso, verificou-se que a exposição de 46 ao reagente de Wittig por um período prolongado produzia uma quantidade muito grande de subprodutos.

Após extensa investigação das melhores condições reacionais, verificou-se que quando a reação foi interrompida ("quenching") após 5 minutos, o produto 47 era isolado em melhor rendimento (78\%) recuperando-se uma pequena quantidade do material de partida 46. (Esquema 19). 


\section{Esquema 19}
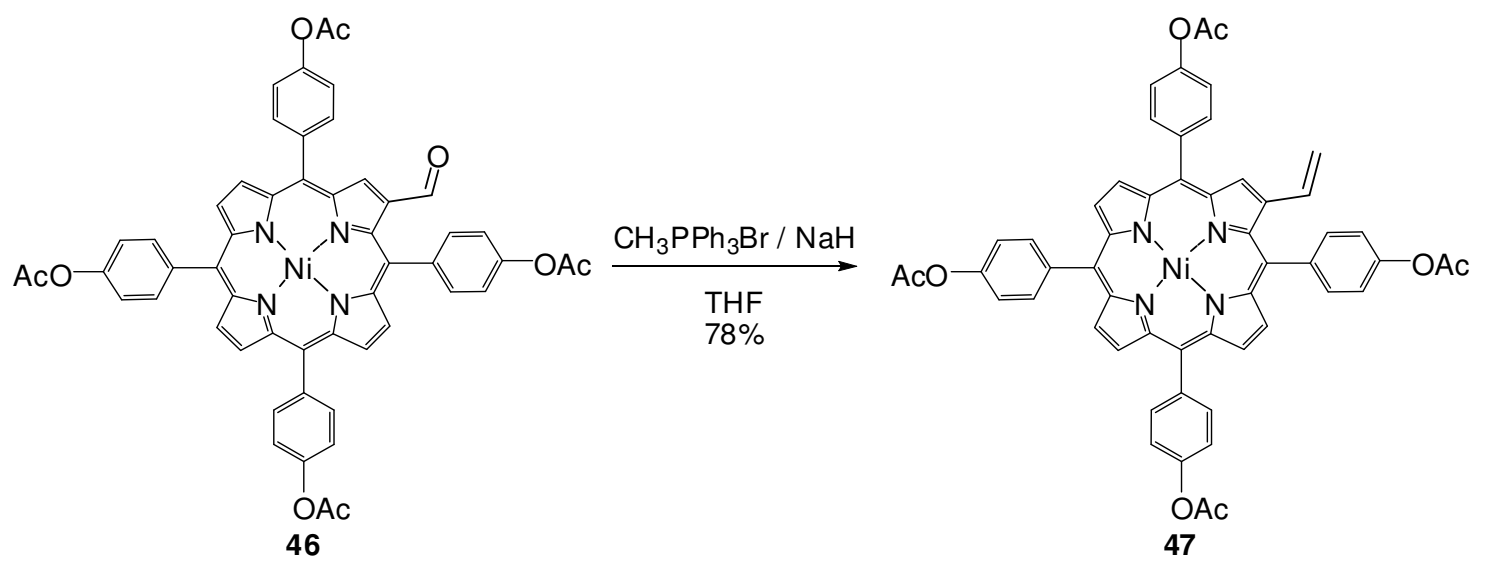

Assim, foi preparado o produto 47, uma nova vinil-porfirina devidamente funcionalizada para os propósitos futuros de transformá-la em clorina e, ao mesmo tempo, um composto com grupos hidrofílicos.

Em seguida, realizou-se a retirada dos grupos acetil com $\mathrm{K}_{2} \mathrm{CO}_{3} / \mathrm{MeOH}$ à temperatura ambiente, obtendo-se 48 com um rendimento de 98\% (Esquema 20).

\section{Esquema 20}
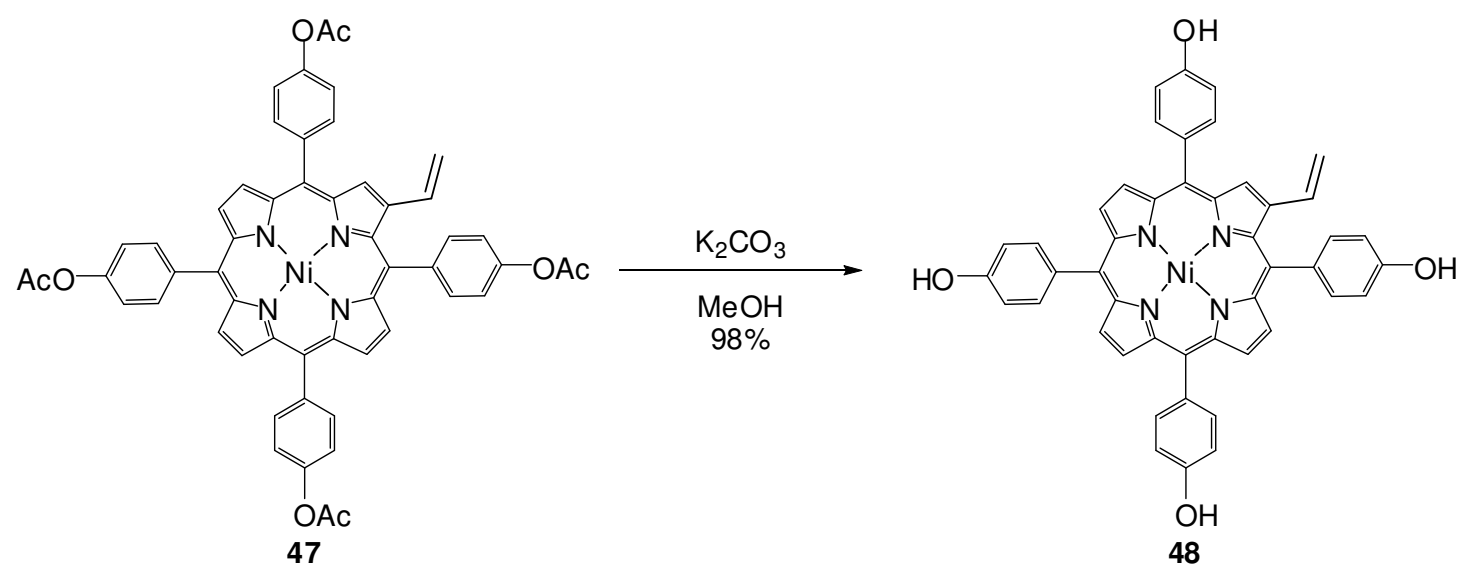

Nos Esquemas 21 e 22 são mostrados os rendimentos globais de obtenção das vinilporfirinas até então sintetizadas. Muito provavelmente a diferença no grupo funcional (efeito doador do grupo metóxi ou sacador de elétrons do grupo acetóxi para o anel aromático) altera as densidades eletrônicas nos grupos aril e no próprio macrociclo porfirínico implicando numa considerável diferença na eficiência das reações realizadas, o que pode ser visto comparando os rendimentos globais das reações de obtenção de 40, 47 e 48 . 


\section{Esquema 21}

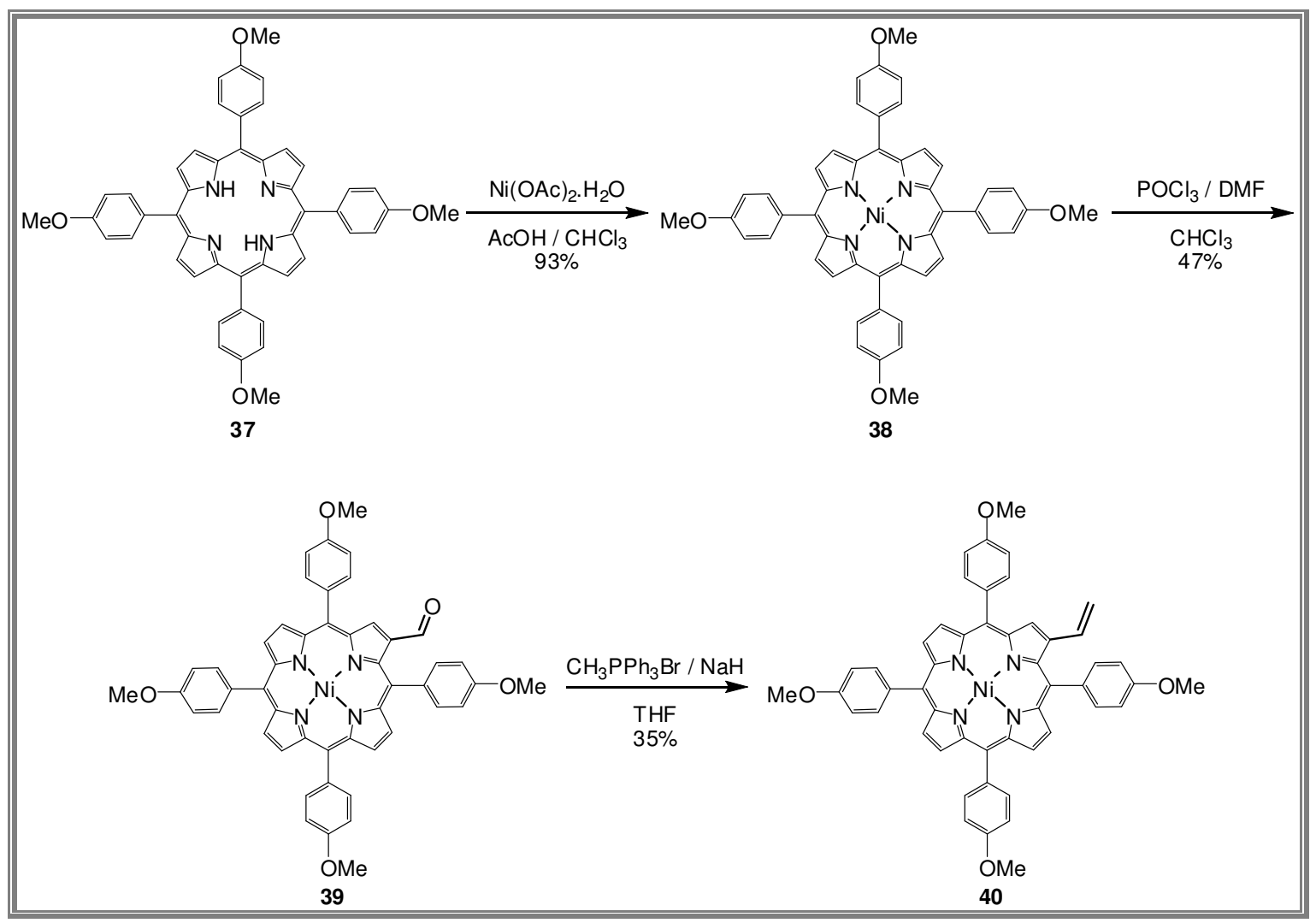

Rendimento Global: 15,3\%

\section{Esquema 22}

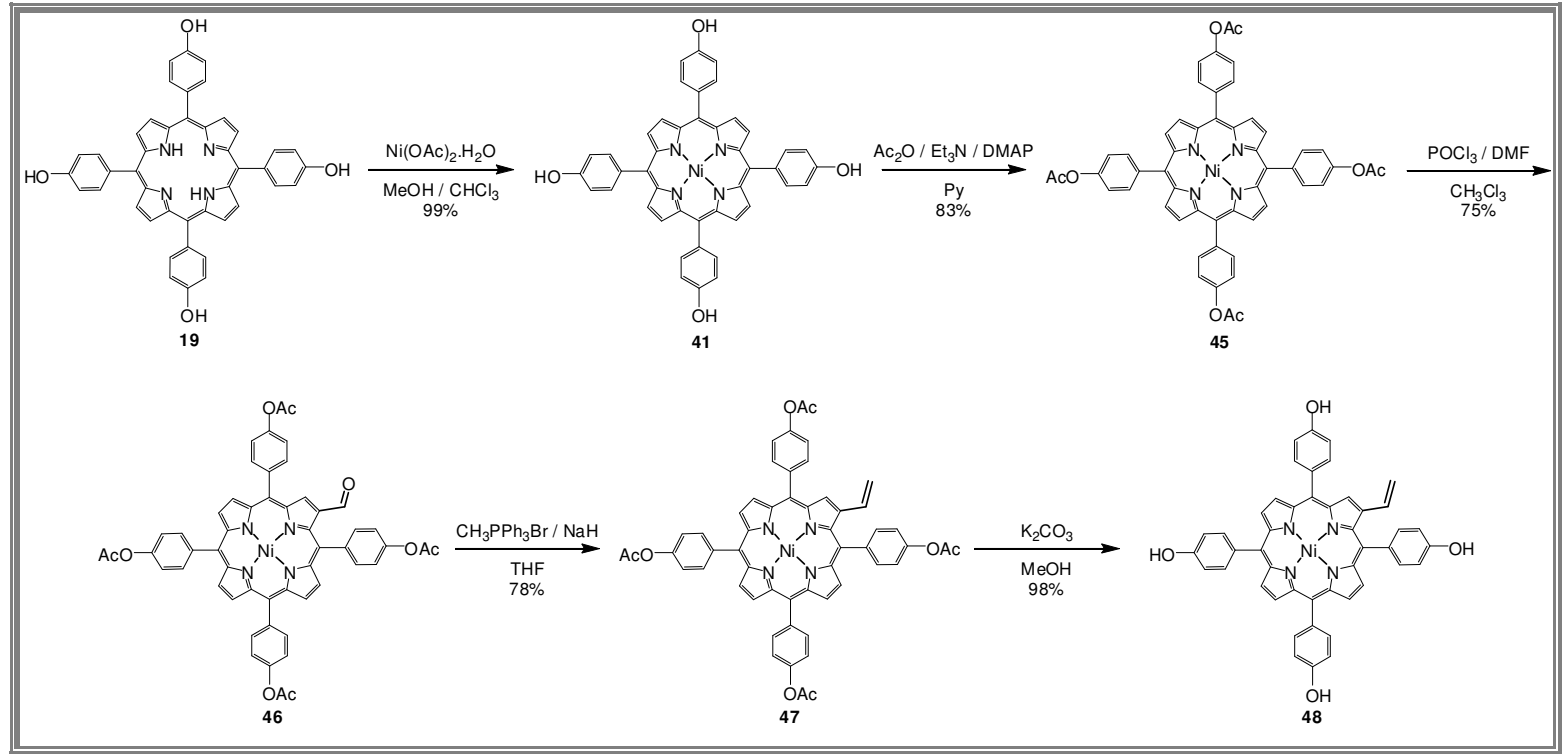

Rendimentos Globais: 47 (48\%); 48 (47\%). 


\section{Abordagem Sintética Baseada na Reação de Diels-Alder}

Após a obtenção das duas novas vinil-porfirinas 47 e 48, foram realizados vários testes reacionais para avaliar a utilização do anidrido maleico como dienófilo em uma reação de Diels-Alder com 47, utilizando o processo já dominado pelo grupo. ${ }^{33}$ De uma maneira geral, nossa metodologia consiste em realizar reação de Diels-Alder (síntese da clorina) e uma posterior abertura do anidrido com nucleófilos (Esquema 23).

\section{Esquema 23}

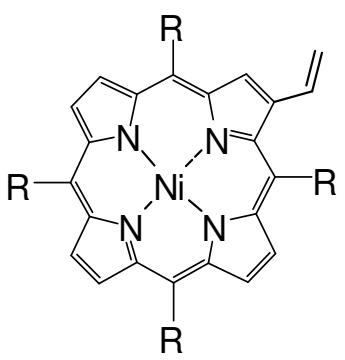

47) $\mathrm{R}=p-\mathrm{PhOAc}$

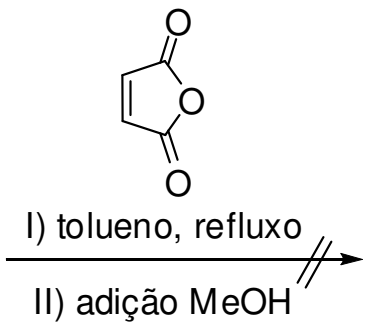

49) $\mathrm{R}=p$-PhOAc

A abertura do anidrido ao término da reação é necessária para que no processo de purificação não houvesse a possibilidade de formação de produtos de degradação em sílica (hidrólise do anidrido) conforme observado em estudos realizados por nosso grupo e colaboradores. ${ }^{33}$

Neste ponto, fomos surpreendidos com um resultado um tanto quanto indesejado. A reação de Diels-Alder foi realizada com sucesso em tolueno à refluxo utilizando excesso de anidrido maleico (5 equivalentes), verificando-se que a clorina se formava durante o processo reacional, como pode ser visto no espectro de UV-VIS da mistura reacional (Figura 6). 


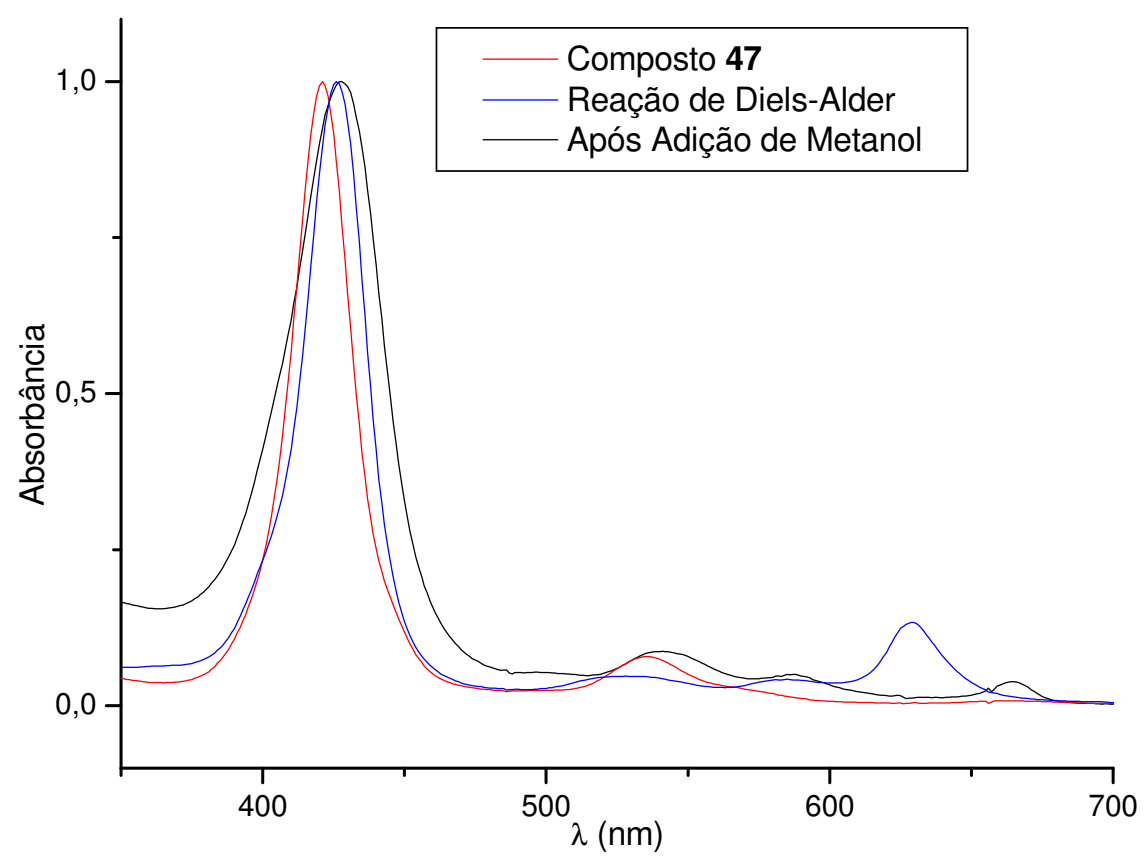

Figura 6: Acompanhamento da reação ilustrada no Esquema 21.

Com a adição de metanol ficava resolvido um problema inerente ao uso de anidridos em procedimentos que necessitam de purificação por métodos cromatográficos (hidrólise na sílica ou em outras fases estacionárias). Entretanto, observou-se que após a adicionar metanol anidro sobre o meio reacional a banda de clorina desaparecia (Figura 6) e por TLC notava-se o aparecimento de vários subprodutos. Tal observação foi confirmada realizando-se uma análise de $\mathrm{RMN}$ de ${ }^{1} \mathrm{H}$ da mistura dos produtos onde não foi observado nenhum indício de presença de clorina. No Esquema 24 é apresentada a proposta de mecanismo reacional em que acontece o rearranjo de clorina para a possível porfirina 50, excetuando-se é claro as possíveis hidrólises dos grupos acetatos, o que justifica a formação dos vários produtos reacionais.

\section{Esquema 24}<smiles>C=Cc1cccc(=O)o1</smiles>

47) $R=O A C$

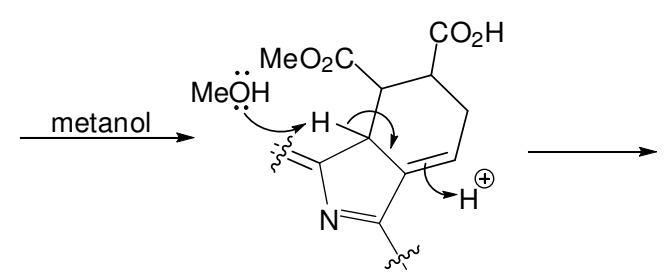<smiles>CC(=O)C1CN(C)C2=C1C(C(=O)O)CCC2</smiles>

50) $R$ = OAC

Sendo assim, os resultados obtidos anteriormente levam-nos a crer que insistir nesta metodologia com as porfirinas 20 e $21 \mathrm{com}$ o objetivo de obter clorinas seria um tanto quanto 
inadequado. Muito provavelmente seriam alcançados resultados iguais a aqueles com o material de partida 47 . Entretanto, havia uma solução adequada e que se pretendia realizar.

Como se sabe, estruturas como as benzoporfirinas (Esquema 25) são extremamente importantes para uso em TFD e vêm sendo estudas por vários grupos de pesquisa. ${ }^{13 \mathrm{~m}, 34}$

\section{Esquema 25}

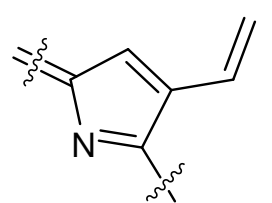

51

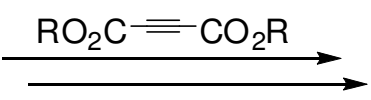

Assim, visto que a reconjugação no anel benzoporfirínico ocorre com relativa facilidade segundo alguns trabalhos da literatura,${ }^{34}$ planejou-se a reação com alcinos, o que possivelmente deveria favorecer a aromatização após a reação de Diels-Alder (mesmo sendo necessário o uso de oxidantes).

Dessa forma, foi planejada uma sistemática de reações de Diels-Alder entre 47 e 26, como é ilustrado no Esquema 26, o que poderia formar tanto 53 como 54, apenas variando a temperatura ou uso de oxidantes.

\section{Esquema 26}

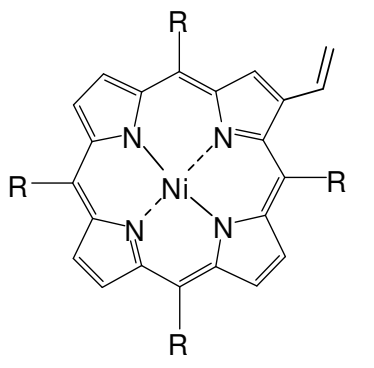<smiles>[13CH3]</smiles>
tolueno

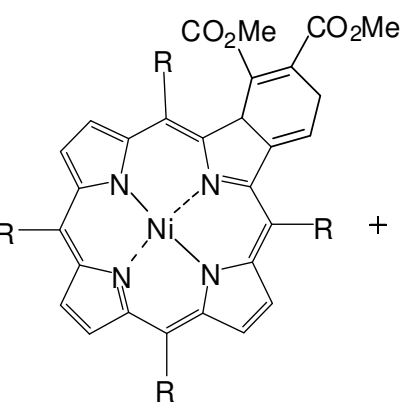

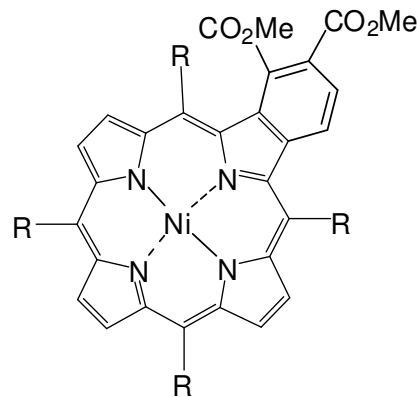

Todas as reações foram inicialmente realizadas em tubo selado sob atmosfera inerte de argônio e aquecimento controlado. Em todos os testes acima citados houve o total consumo do material de partida e, no final, os resultados foram similares. As condições experimentais dos principais testes são mostradas na Tabela 1 .

Tabela 1: sistemática de reações de Diels-Alder entre 47 e 26. 


\section{Equivalentes \\ de 26 \\ Solvente Temperatura Uso de oxidante}

\begin{tabular}{ccccc}
\hline Teste 1 & 50 & tolueno & 70 & não \\
Teste 2 & 200 & tolueno & 120 & excesso de $26+$ ar \\
Teste 3 & 50 & tolueno & 120 & p-cloranil \\
\hline
\end{tabular}

Já no primeiro teste reacional (condição mais branda, Teste 1) foi possível observar por UV-VIS a formação de uma clorina, possivelmente o produto 53, conforme ilustrado na Figura 7. Neste sentido, decidiu-se isolar o produto majoritário desta reação utilizando-se sílica, dentre outras fases estacionárias.

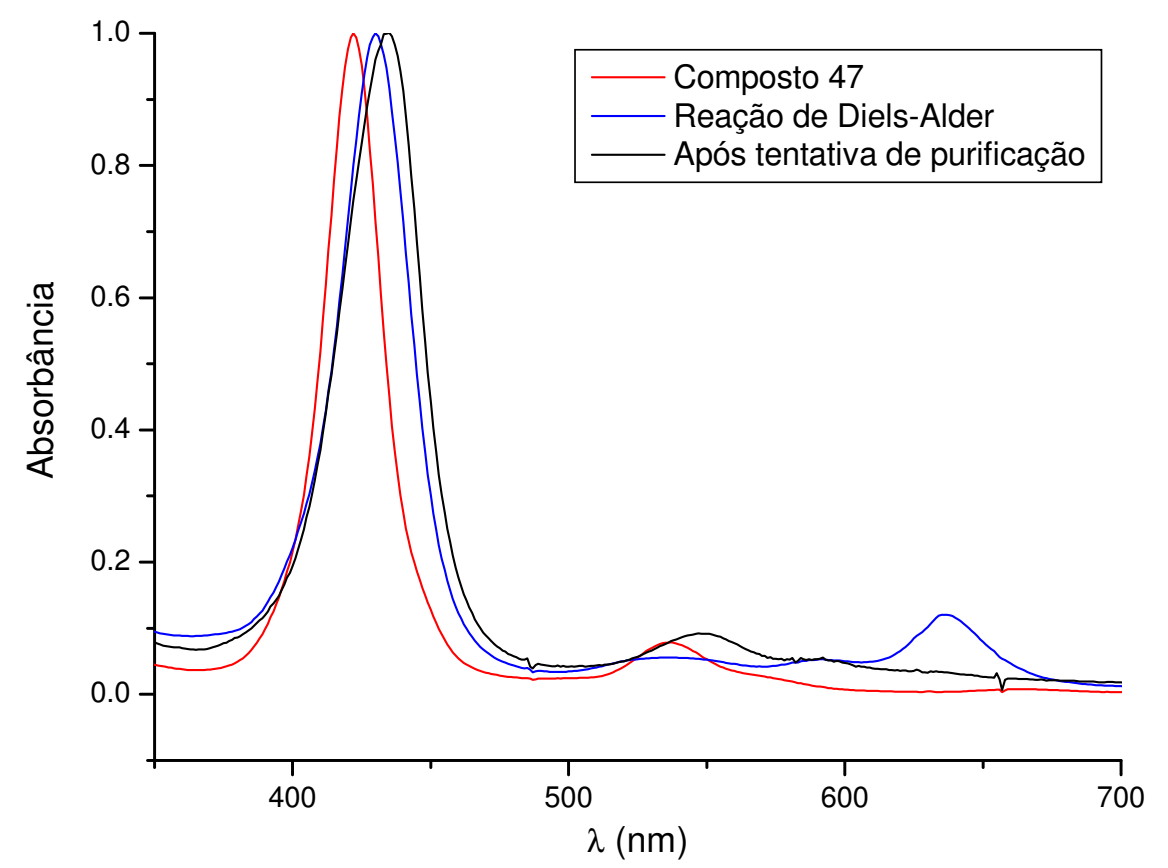

Figura 7: Acompanhamento do Teste 1 por UV-VIS.

Durante o processo de purificação, independentemente da fase estacionária, ${ }^{\text {ii }}$ observouse uma completa degradação do produto reacional em diversos outros subprodutos. A análise de alguns destes produtos por UV-VIS deixou claro que nenhum destes compostos era do tipo clorina.

\footnotetext{
${ }^{i i}$ Neste caso foram testadas as fases estacionárias: sílica, sílica/ $\mathrm{Et}_{3} \mathrm{~N} 1 \%$, alumina e florisil.
} 


\section{Esquema 27}<smiles>C=CC1=CC(=[V])N=C1C#N</smiles>

47) $\mathrm{R}=\mathrm{OAc}$

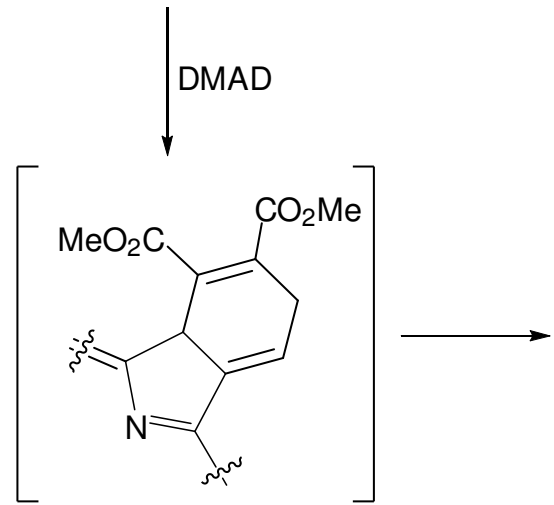

53) $R=O A C$

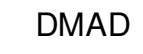<smiles></smiles>

54) $R=O A C$

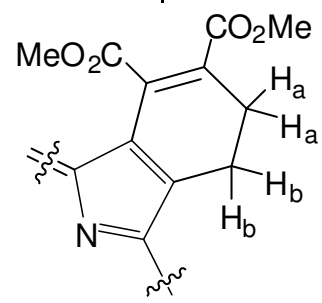

55) $R=O A C$

O Teste 2 foi realizado utilizando-se um excesso maior de DMAD (26) (200 equivalentes); neste caso, é conhecido que o dienófilo 26 atua também como oxidante durante o processo de conversão à benzoporfirina. ${ }^{34 b}$ Nestas condições e após as 24 horas de reação observou-se uma completa degração do material de partida não se obtendo nenhum produto do tipo benzoporfirina. De maneira similar no Teste 3 (com utilização de oxidante no final da reação) não se obteve nenhum produto do tipo benzoporfirina. A primeira etapa de formação da clorina ocorreu normalmente a exemplo do teste 1, entretanto, após adicionar p-cloranil novamente foi obtida uma mistura complexa.

Estes resultados nos levaram a concluir que, apesar dos exemplos bem sucedidos presentes na literatura, ${ }^{34 \mathrm{~b}}$ neste caso, ocorre um número elevado de reações laterais nas condições experimentadas. Muito provavelmente a degradação dos grupos acetato, acompanhada de algumas reações de polimerização durante a oxidação, fornece as misturas complexas supracitadas, impossibilitando o isolamento da benzoporfirina $\mathbf{5 4}$ desejada. 


\section{Estudos Fotofísicos Realizados com novas Clorinas}

Os compostos 58 e 59, cuja preparação é apresentada no Esquema $28,^{33}$ foram sintetizados em colaboração com o pós-doutorando Kleber Thiago de Oliveira (grupo de porfirinas de Ribeirão Preto). Os testes preliminares de atividade fotodinâmica foram realizados em nosso laboratório e os resultados mostraram-se bastante promissores.

\section{Esquema 28}
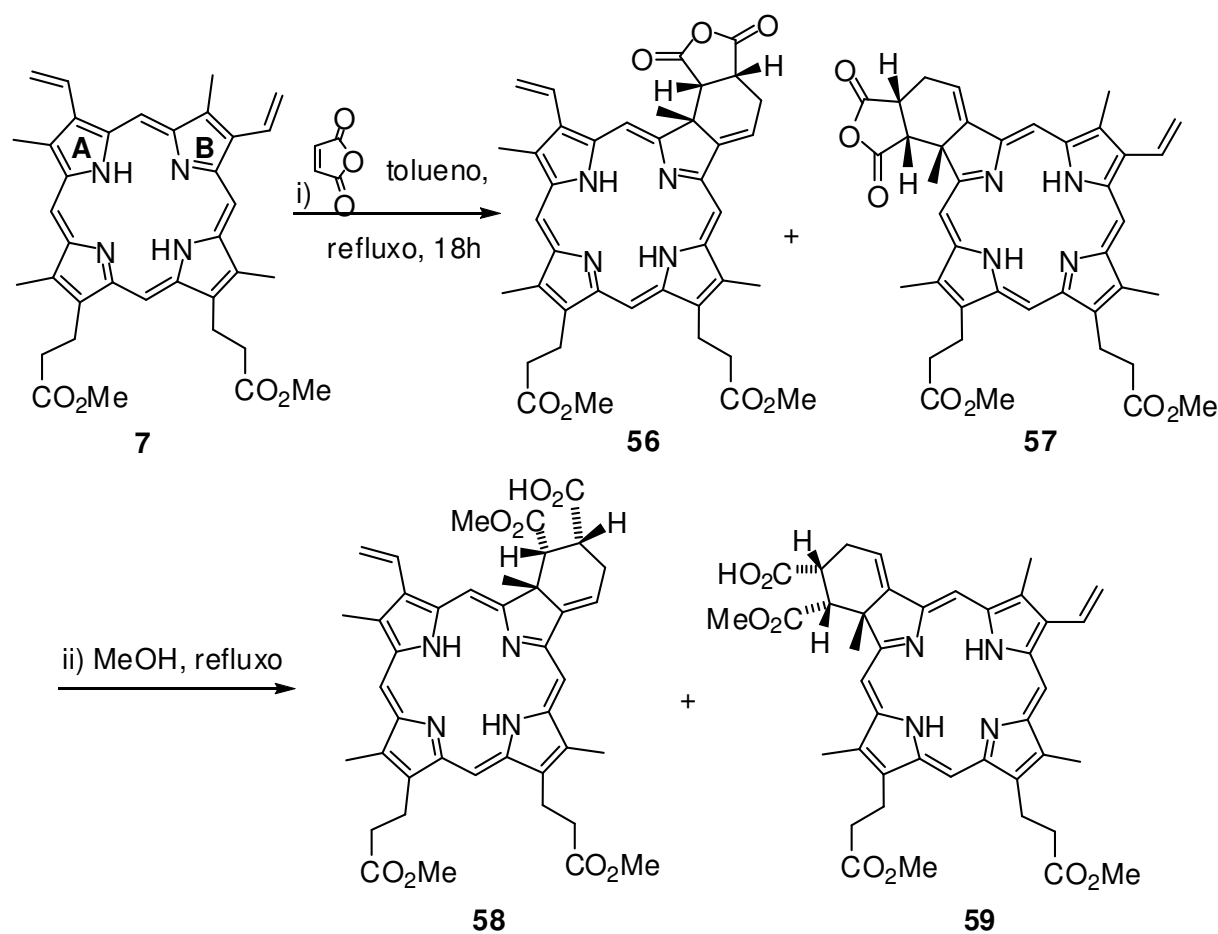

Considerando os espectros de UV-VIS dos adutos obtidos (Figura 8), ambos possuem uma banda de absorção intensa na região da janela terapêutica $(\sim 670 \mathrm{~nm})$.
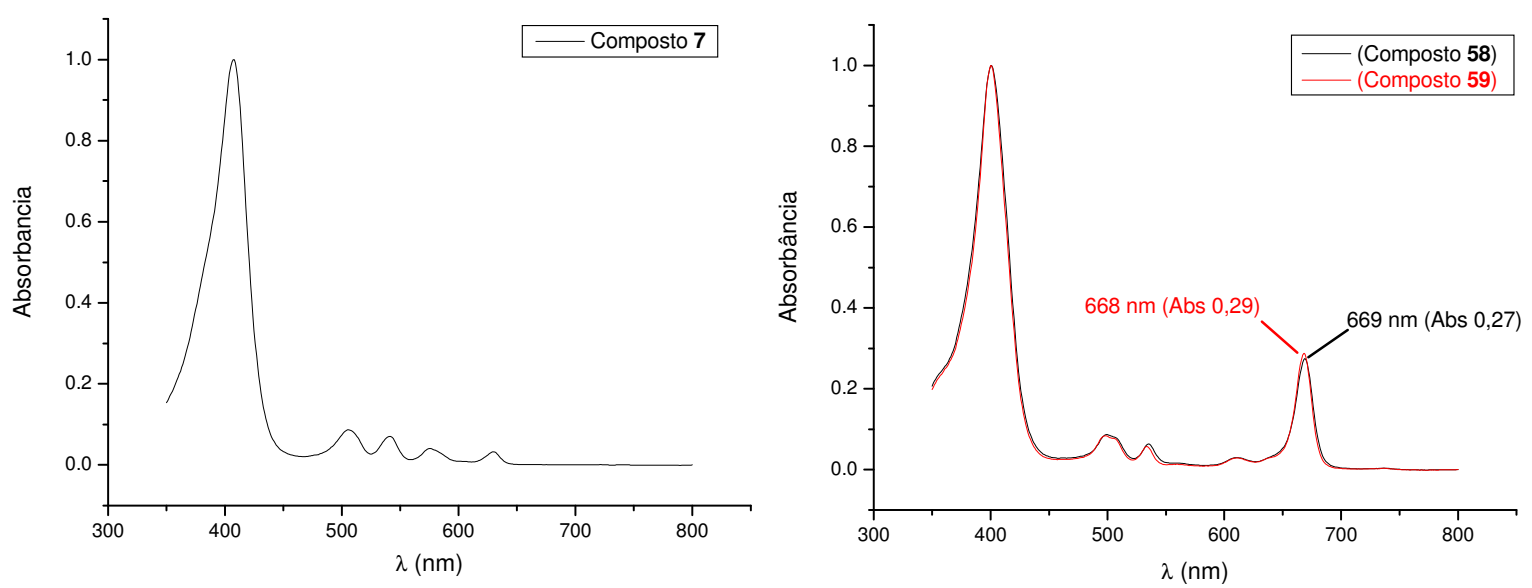

Figura 8: Espectros de UV-VIS dos compostos 7, 58 e 59 em EtOAc. 
Foram realizados testes preliminares em cada um dos compostos para avaliar a formação de oxigênio singlete em solução. O teste em que é observada a degradação do ácido úrico (conforme Figura 9) mede indiretamente a formação de oxigênio singlete $\left({ }^{1} \mathrm{O}_{2}\right)$, indicando assim a atividade fotodinâmica do composto. ${ }^{35}$
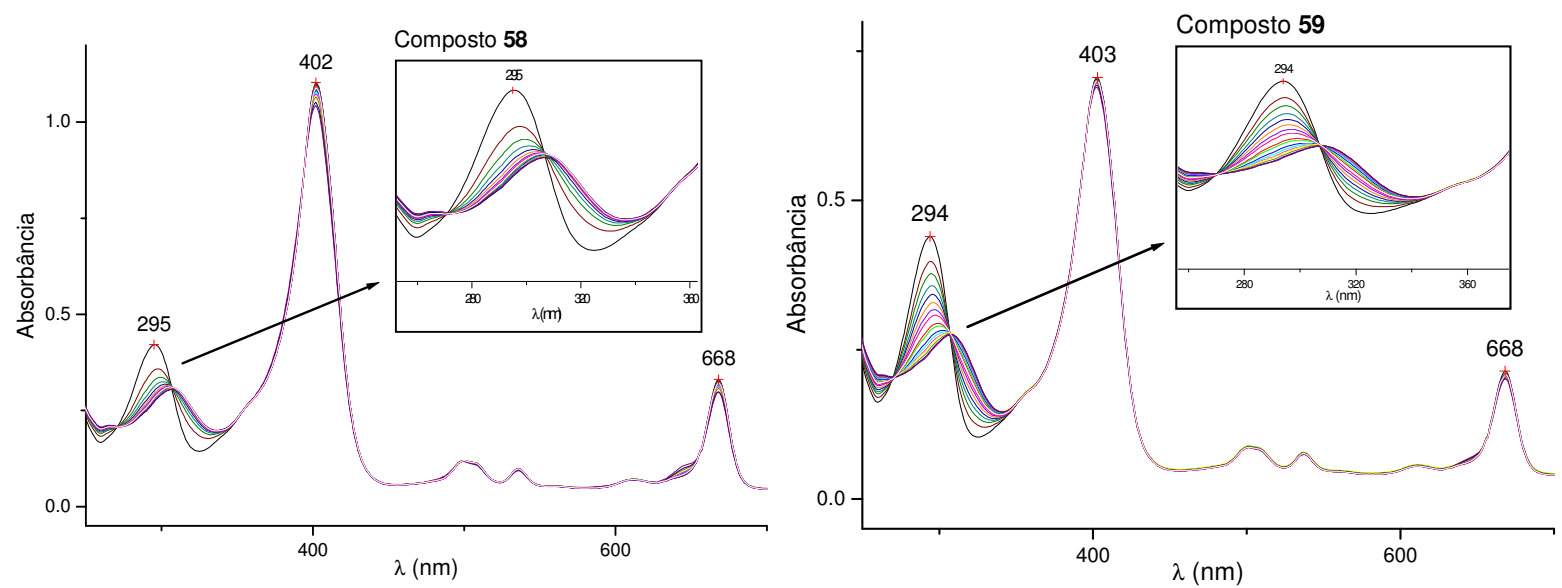

Figura 9: degradação do ácido úrico utilizando os compostos 58 e 59.

Dessa forma, mesmo que em diferentes ambientes químicos, foi possível fazer uma comparação da atividade fotodinâmica (AF) de 58 e 59 com um fotossensibilizador comercial (Photofrin II). Tais valores foram obtidos a partir da expressão de Fischer, ${ }^{35}$ mostrada abaixo

$$
\mathrm{AF}=\left(\Delta \mathrm{A}_{\mathrm{UA}} \cdot 10^{5}\right) /\left(\mathrm{E}_{0} \cdot \mathrm{t} \cdot \mathrm{A}_{\mathrm{PS} \text { lirr }}\right)
$$

onde $\mathrm{AF}=$ atividade fotodinâmica; $\Delta \mathrm{A}_{\mathrm{AU}}=$ diminuição da absorbância da banda do ácido úrico; $\mathrm{E}_{0}=$ potência do laser $(\mathrm{mW}) ; \mathrm{t}=$ tempo de irradiação $(\mathrm{s})$ e $\mathrm{A}_{\mathrm{FSlirr}}=$ absorbância do fotossensibilizador.

Por fim, os valores da Atividade Fotodinâmica (AF) que foram obtidos para estes compostos estão apresentados na Tabela 2.

Tabela 2. Valores de AF para os compostos 58 e 59 em etanol determinados pela expressão de Fischer. ${ }^{35}$

FS

$\Delta \mathrm{A}_{\mathrm{AU}}$

0,61

0,15

0,19
$\mathrm{A}_{\mathrm{FS}} \lambda_{\mathrm{irr}}$

0,07

0,23

0,15
AF

23,9

71,8

138,6 
As clorinas 58 e 59 foram sintetizadas a partir de uma rota sintética simples; estas são compostos com uma grande absorção na região da janela terapêutica. A atividade fotodinâmica das clorinas 58 e 59 é significativamente maior comparada à do "Photofrin", indicando que estes compostos são realmente promissores para uso em TFD. Neste momento estão sendo realizados alguns testes biológicos em colaboração com a Faculdade de Ciências Farmacêuticas de Ribeirão Preto - USP. 


\section{Conclusões e Consideraçôes Finais}




\section{6 - Conclusões e Considerações Finais.}

A síntese de porfirinas é, em geral, baseada em reações de condensação que acontecem em baixos rendimentos, como nos métodos de Rothmund (1mg de porfirina para cada $1 \mathrm{~g}$ de pirrol), ${ }^{36}$ Adler-Longo $(-20 \%)^{37}$ e Lindsey $(30-40 \%){ }^{38}$ Uma nova metodologia proposta por Bonar-Law $(-35 \%)^{39}$ foi abordada para a obtenção do composto 19 em pequenas quantidades, já no término da elaboração do presente trabalho. Como se pôde ver, o preço pago pelos derivados porfirínicos é diretamente proporcional à dificuldade na produção dos mesmos, principalmente os assimétricos. ${ }^{\text {iii }}$

Modificações na estrutura das porfirinas também são relatadas como de difícil manipulação, devido ao fato que várias reações paralelas acontecem, formando assim misturas de vários subprodutos indesejáveis. A purificação do produto em questão acaba sendo uma tarefa árdua e desgastante, obrigando o pesquisador a recorrer muitas vezes a variadas técnicas cromatográficas. Desta forma, a preparação de novos derivados porfirínicos representa ainda um grande desafio para os químicos orgânicos sintéticos. Esta é uma tarefa que exige criatividade, inteligência e perseverança e tem como alicerce o contínuo desenvolvimento de metodologias sintéticas e o aperfeiçoamento constante das técnicas de separação e análise orgânica.

Neste trabalho foram preparadas duas novas vinil-porfirinas (47 e 48), com o objetivo de obter através da reação de Diels-Alder, compostos do tipo clorina ou benzoporfirina. A metodologia utilizada passa pela preparação de derivados mono-formilados que foram sistematicamente preparados através da reação de Vilsmeier.

Neste caso, foram obtidos resultados bastante interessantes dentro da química de tetrafenilporfirinas, uma vez que se verificou que grupos doadores de elétrons ligados aos grupos fenil tornam a reação menos eficiente; muito provavelmente os grupos doadores ativam tanto o anel porfirínico quanto os próprios anéis aril, promovendo poliformilações. Por outro lado, a presença de grupos de médio efeito retirador de elétrons (por exemplo, acetatos) torna o processo de mono-formilação ideal, ou seja, não impede a ocorrência de monoformilação, porém inibe as demais reações paralelas (comparações explicitadas nos Esquemas 21 e 22).

\footnotetext{
iii Preço de algumas porfirinas comerciais: protoporfirina IX dimetil éster (7), $\mathrm{R} \$ 948,80$ (500 mg); tetra(phidróxifenil)porfirina, R \$ 610,52 (1 g). Fonte: http://www.sigma-aldrich.com.br
} 
É conhecido que na presença de grupos fortemente retiradores de elétrons como nas tetra(pentafluorofenil)porfirinas não há ocorrência de formilação. Assim, concluiu-se que o uso de acetatos em posições pára aos grupos fenil são extremamente eficientes no processo de formilação de tetrafenilporfirinas.

Com relação aos estudos sobre a síntese de clorinas via reação de Diels-Alder com viniltetrafenilporfirinas, foi possível concluir que, estes resultados somados à outros vários trabalhos do grupo de pesquisa, demonstram claramente a dificuldade de se isolar clorinas não substituídas nas posições $\beta$-pirrólicas vizinhas ao grupo vinil. Alguns trabalhos da literatura bem como nossa pesquisa demonstram claramente que clorinas derivadas da protoporfirina IX dimetil éster (7) são extremamente estáveis e podem ser produzidas com eficiência via reação de Diels-Alder, isso porque esta porfirina encontra-se devidamente substituída.

Desta forma, as duas novas vinilporfirinas aqui sintetizadas certamente serão consideradas em trabalhos futuros de nosso grupo, com o objetivo de produzir compostos de interesse. Dentre as possibilidades, destacamos a de preparar "dyads" do tipo porfiririnaftalocianina através de funcionalizações via grupo vinil no sentido de produzir ftalonitrilos; a presença de grupos hidrofílicos no macrociclo porfirínico deverá contribuir para a produção de sistemas ideais para estudos de tranferência de energia ou mesmo para testes voltados para TFD. 


\section{Parte Experimental}




\section{7 - Parte Experimental.}

- Os espectros de ressonância magnética nuclear de hidrogênio $\left({ }^{1} \mathrm{H}\right)$ foram obtidos a 300, 400 e $500 \mathrm{MHz}$ em espectrômetros Bruker DPX-300, Bruker DRX-400 e Bruker DRX-500 respectivamente. Os deslocamentos químicos $(\delta)$ estão relatados em parte por milhão (ppm) em relação ao tetrametilsilano (TMS), utilizado como padrão interno, colocando-se entre parênteses a multiplicidade $(\mathrm{s}=$ singleto,

- $\quad{ }^{\text {iv }} \mathrm{s} . \mathrm{l}=$ singleto largo, $\mathrm{d}=$ dubleto, $\mathrm{t}=$ tripleto, $\mathrm{q}=$ quadrupleto, quint= quintupleto, $\mathrm{d} . \mathrm{d}$ = duplo dubleto, d.d.d = duplo duplo dubleto, d.d.d.d = duplo duplo duplo dubleto, d.d.d.d.d = duplo duplo duplo duplo dubleto, d.d.t.d. = duplo duplo triplo dubleto, d.t $=$ duplo tripleto, d.d.t $=$ duplo duplo tripleto, d.d.d.t $=$ duplo duplo duplo tripleto, d.q = duplo quadrupleto, d.d.q = duplo duplo quadrupleto, t.t $=$ triplo tripleto, t.d.d $=$ triplo duplo dubleto, dquint $=$ duplo quintupleto, $\mathrm{q} \cdot \mathrm{q}=$ quadruplo quadrupleto, $\mathrm{m}=$ multipleto.), a constante de acoplamento $(J)$ em Hertz $(\mathrm{Hz})$ e o número de hidrogênios deduzidos da integral relativa.

- $\quad$ Os espectros de ressonância magnética nuclear de ${ }^{13} \mathrm{C}$ foram obtidos a 75,100 e 125 $\mathrm{MHz}$ em espectrômetros Bruker DPX-300, Bruker DRX-400 e Bruker DRX-500, respectivamente. Estes espectros foram traçados utilizando-se as seguintes técnicas:

${ }^{13} \mathrm{C}\left\{{ }^{1} \mathrm{H}\right\}$ - Carbono Totalmente Desacoplado de Hidrogênio

DEPT-135 - Distortionless Enhancement by Polarization Transfer

- As análises de espectroscopia de correlação $\left({ }^{1} \mathrm{H}-{ }^{13} \mathrm{C}\right)(\mathrm{RMN}-2 \mathrm{D})$ foram realizadas no espectrômetro Bruker DRX-500, de acordo com a necessidade durante a atribuição dos compostos. Foram utilizadas técnicas como ${ }^{1} \mathrm{H}-{ }^{1} \mathrm{H}$ gCOSY, gJ-res, ${ }^{1} \mathrm{H}_{-}{ }^{13} \mathrm{C}$ gHMQC, ${ }^{1} \mathrm{H}-{ }^{13} \mathrm{C}$ gHMBC.

- As cromatografias em camada delgada (CCD) foram realizadas utilizando-se placas de sílica gel 60 da Merck $^{\circledR}$. As purificações por cromatografia em coluna foram realizadas utilizando sílica gel 80-230 e 200-400 mesh da ACROS ${ }^{\circledR}$.

- Para concentrar as soluções orgânicas foram utilizados evaporadores do tipo Heidolph e Büchi, operando à pressão de aproximadamente $60 \mathrm{mmHg}$.

\footnotetext{
iv Segundo recomendação da AUREMN - Associação dos Usuários de Ressonância Magnética Nuclear - deve-se atualmente utilizar "simpleto" além de outras sugestões de mudança na nomenclatura destes termos, aqui não incorporadas.
} 
- Para análises térmicas foi utilizado um sistema TA Instruments SDT 2960 Simultaneous DTA-TGA Thermal Analyst 2100.

- Os experimentos preliminares de atividade fotodinâmica foram realizados utilizando laser de estado sólido com potência de $500 \mathrm{~mW}$ em $661 \mathrm{~nm}$.

- As análises de UV-VIS foram realizadas em espectrofotômetros HP Diode Array 8452 e 8453.

- As análises de espectrometria de MS-ESI-TOF foram realizadas em um equipamento MicroTOF LC (Bruker Daltonics) operando em modo ESI positivo. (Central Analítica - IQ-USP)

- Os solventes e reagentes comerciais foram convenientemente purificados conforme métodos usuais. ${ }^{40}$

- Vale ressaltar que todos os rendimentos apresentados referem-se a condições ótimas reacionais encontradas durante estes estudos. 
7.1 - Preparação do acetato de níquel $\left(\mathrm{Ni}(\mathrm{OAc})_{2} \cdot \mathrm{H}_{2} \mathrm{O}\right)$.

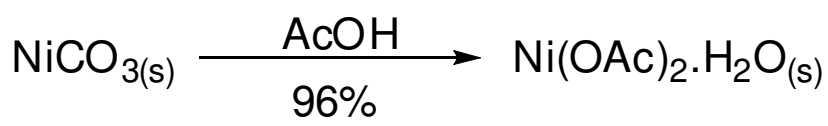

Procedimento: Em uma cápsula de porcelana contendo o carbonato de níquel (5,00 g; 42,1 mmol) foi adicionado lentamente ácido acético glacial sob agitação até $\mathrm{pH} \sim 4$. Na seqüência, a mistura reacional foi aquecida a $80^{\circ} \mathrm{C}$ e, logo depois, o sólido resultante foi deixado em estufa $\left(\sim 100^{\circ} \mathrm{C}\right)$ para a secagem final.

Rendimento: $7,88 \mathrm{~g}(40,4 \mathrm{mmol}) \rightarrow 96 \%$

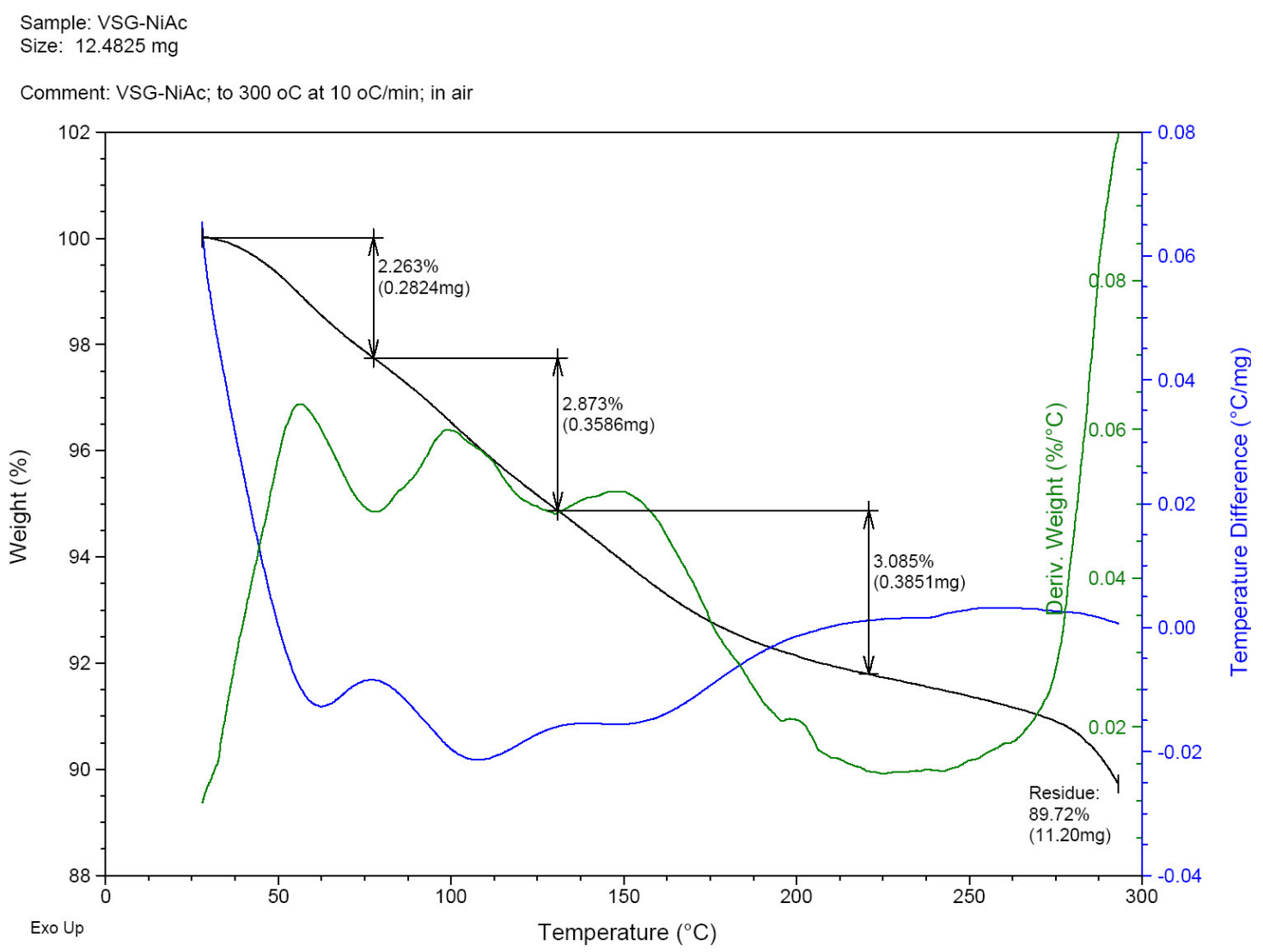

Figura 10: Análise Termogravimétrica do $\mathrm{Ni}(\mathrm{OAc})_{2} \cdot \mathrm{H}_{2} \mathrm{O}$. 
7.2 - Preparação da p-tetrametóxifenilporfirina de níquel (II).

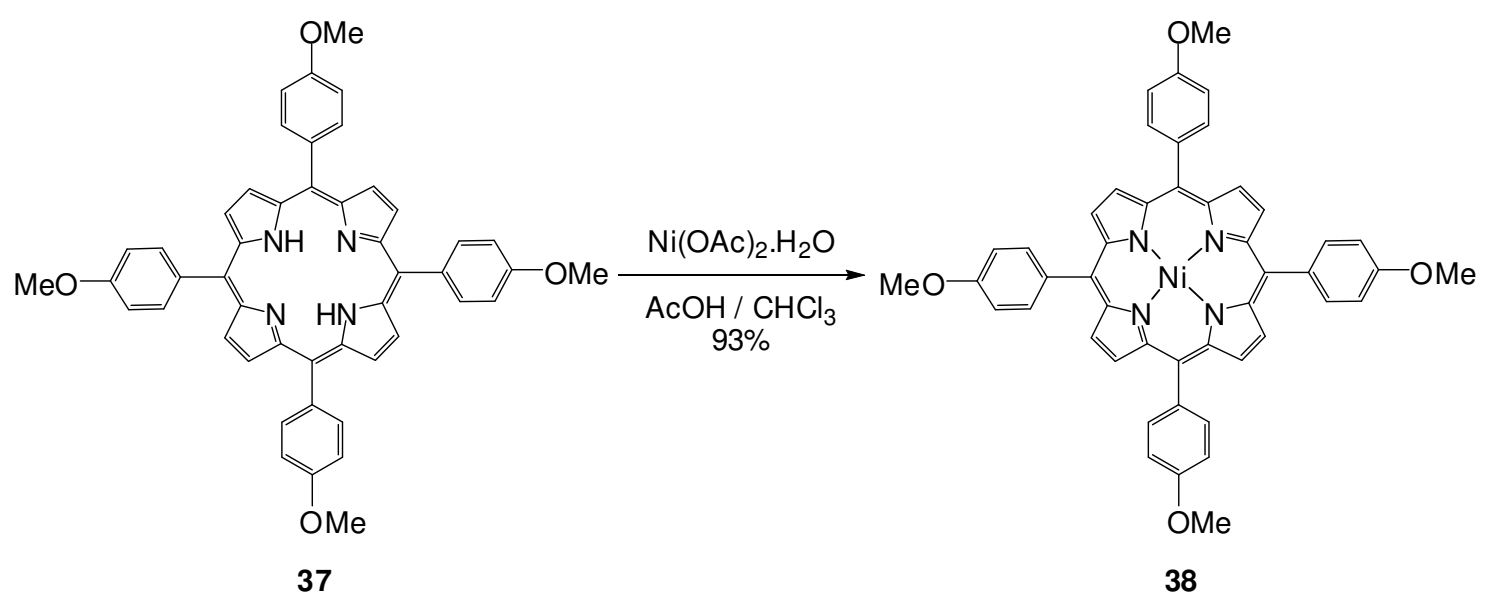

Procedimento: Uma solução contendo 37 (197,5 mg; 0,27 mmol) e $\mathrm{Ni}(\mathrm{OAc})_{2} \cdot \mathrm{H}_{2} \mathrm{O}$ (400 mg; 2,05 mmol) em AcOH (30mL) foi mantida sob forte agitação e refluxo durante 4 horas. Ao término da reação (acompanhada por ccd), adicionou-se $\mathrm{MeOH}(20 \mathrm{~mL}$ ) e a mistura resultante foi resfriada em banho de gelo. O sólido formado foi então filtrado e lavado com 2 porções (5 mL cada) de $\mathrm{MeOH}$ gelado. Por fim, o produto 38 resultante foi mantido em estufa $\left(\right.$ a $\left.60^{\circ} \mathrm{C}\right)$ por uma noite para a secagem final.

Rendimento: $195 \mathrm{mg}(0,25 \mathrm{mmol}) \rightarrow 93 \%$

RMN- ${ }^{1} \mathrm{H}\left(\mathrm{CDCl}_{3}, 400 \mathrm{MHz}\right) \delta(\mathrm{ppm}): 3,49$ (s, 3H); 4,05 (s, 9H); 7,21 (m, 8H); 7,90 (m, 8H); $8,75(\mathrm{~d}, 8 \mathrm{H}, \mathrm{J}=5,0 \mathrm{~Hz})$. 


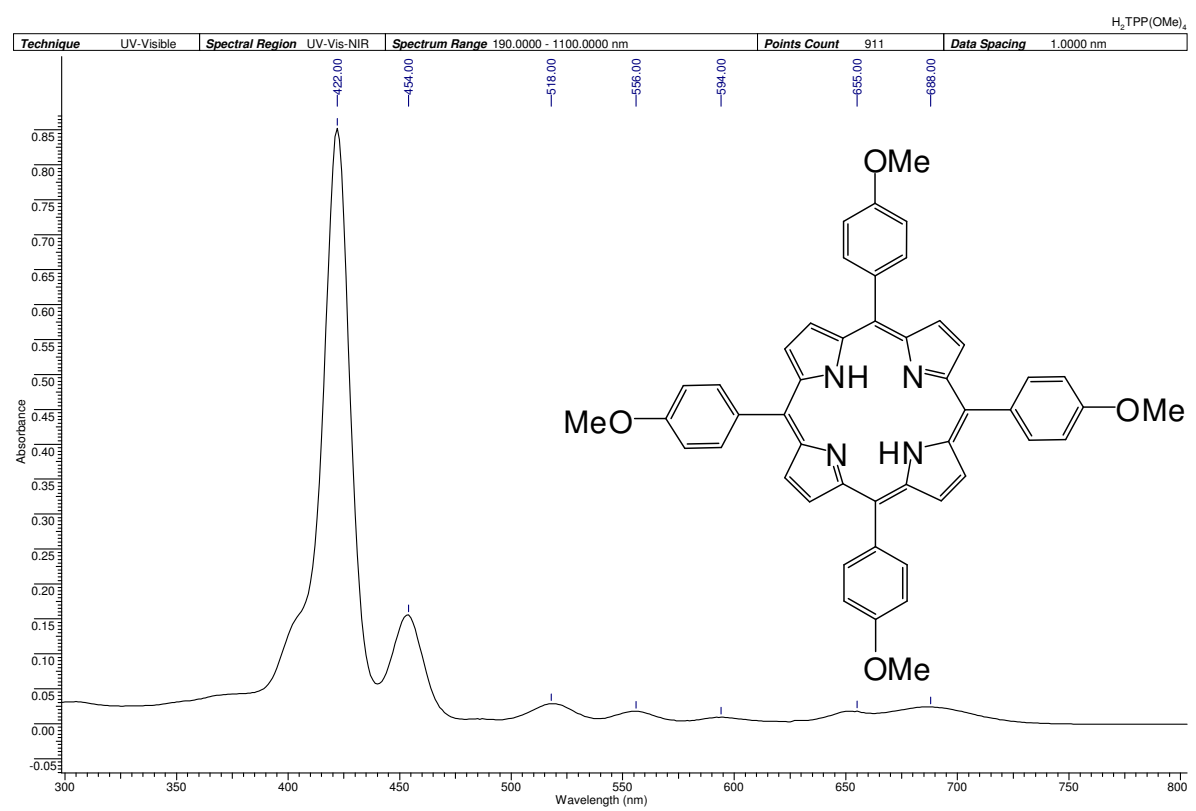

Figura 11: Espectro de UV-VIS do composto $37 \mathrm{em} \mathrm{CHCl}_{3}$.

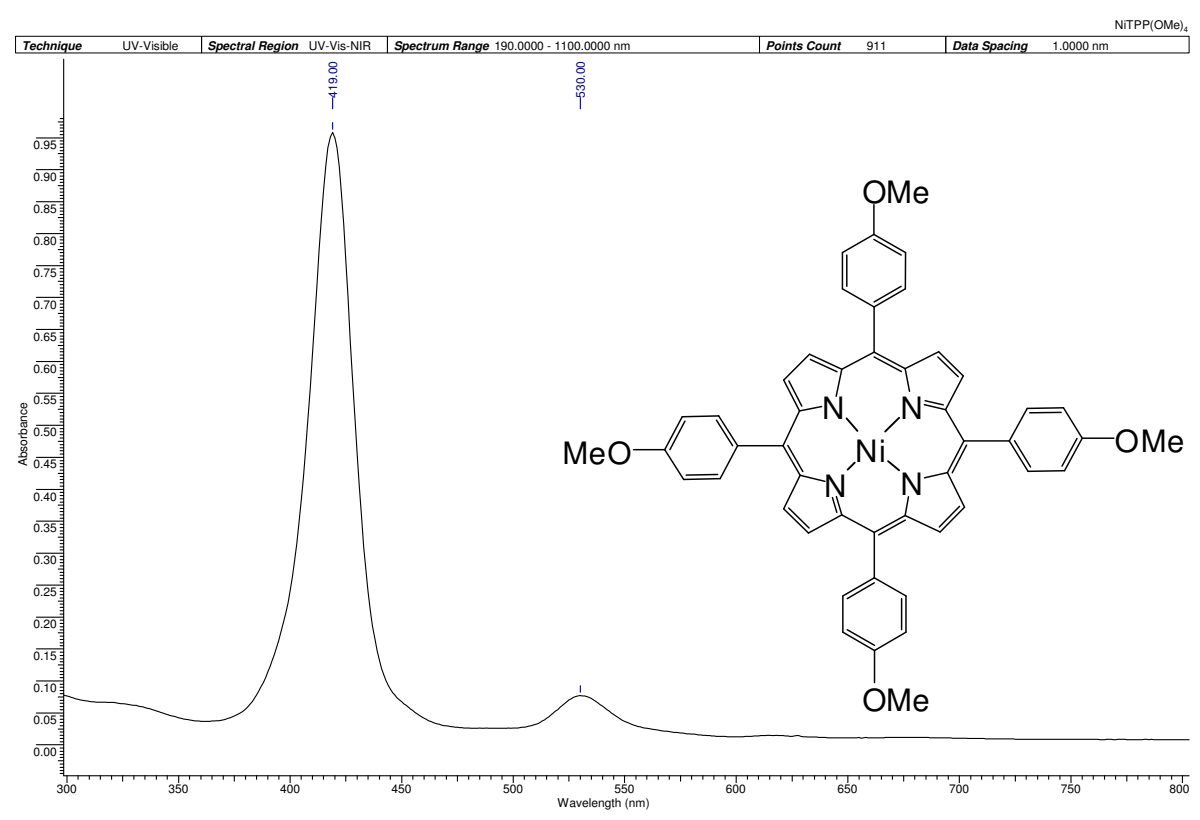

Figura 12: Espectro de UV-VIS do composto $38 \mathrm{em} \mathrm{CHCl}_{3}$. 
7.3 - Preparação da formil p-tetrametóxifenilporfirina de níquel II.

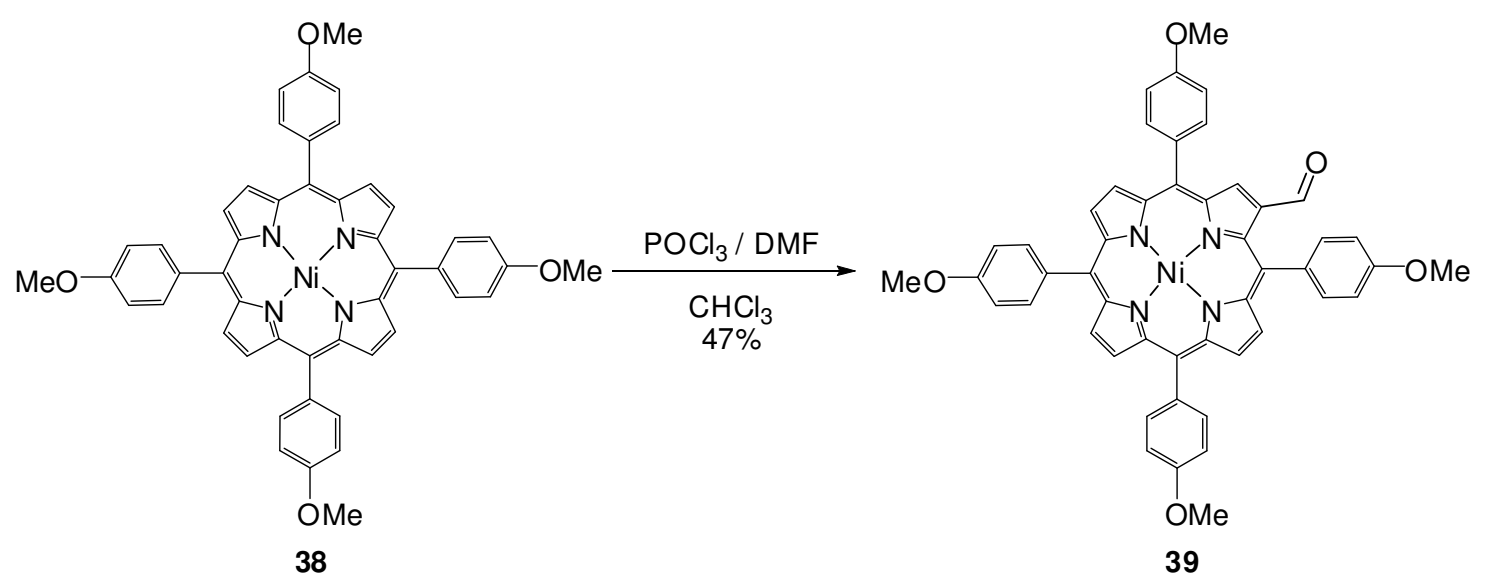

Procedimento: $\mathrm{O}$ complexo de Vilsmeier foi preparado a partir da adição de $\mathrm{POCl}_{3}$ (3,6 mL; 39,5 mmol) em DMF (3 mL; $39 \mathrm{mmol})$ sob atmosfera de argônio. O complexo formado foi mantido sob agitação vigorosa a temperatura ambiente por 30 minutos. Em seguida, sob resfriamento $\left(0^{\circ} \mathrm{C}\right)$, adicionou-se lentamente o composto 38 (110 $\left.\mathrm{mg} ; 0,14 \mathrm{mmol}\right)$ dissolvido em $\mathrm{CHCl}_{3}(80 \mathrm{~mL})$ e a solução resultante foi mantida a refluxo por 4 horas. Após o período descrito, o recipiente reacional foi resfriado (banho de gelo), adicionou-se solução saturada de $\mathrm{NaOAc}$ para elevar o $\mathrm{pH}$ da mistura ( $\mathrm{pH} \sim 9-10$ ), separou-se a fase orgânica e a fase aquosa novamente extraída com $\mathrm{CHCl}_{3}(3 \times 30 \mathrm{~mL})$. A mistura das fases orgânicas foi seca com $\mathrm{Na}_{2} \mathrm{SO}_{4}$, filtrada e o solvente removido em evaporador rotatório. O resíduo foi então purificado em coluna cromatográfica de sílica-gel, utilizando como eluente misturas de $\mathrm{CHCl}_{3}$ :hexano (8:2 - 9:1 - 10:0), sendo que 39 era o produto mais polar.

Rendimento: $54 \mathrm{mg}(66 \mu \mathrm{mol}) \rightarrow 47 \%$

$\mathrm{RMN}-{ }^{1} \mathrm{H}\left(\mathrm{CDCl}_{3}, 400 \mathrm{MHz}\right) \delta(\mathrm{ppm}): 4,02$ (s, 3H); 4,04 (s, 9H); 7,20 (m, 8H); 7,89 (m, 8H); $8,72(\mathrm{~m}, 6 \mathrm{H}) ; 9,29$ (s, 1H); 9,31 (s, 1H). 


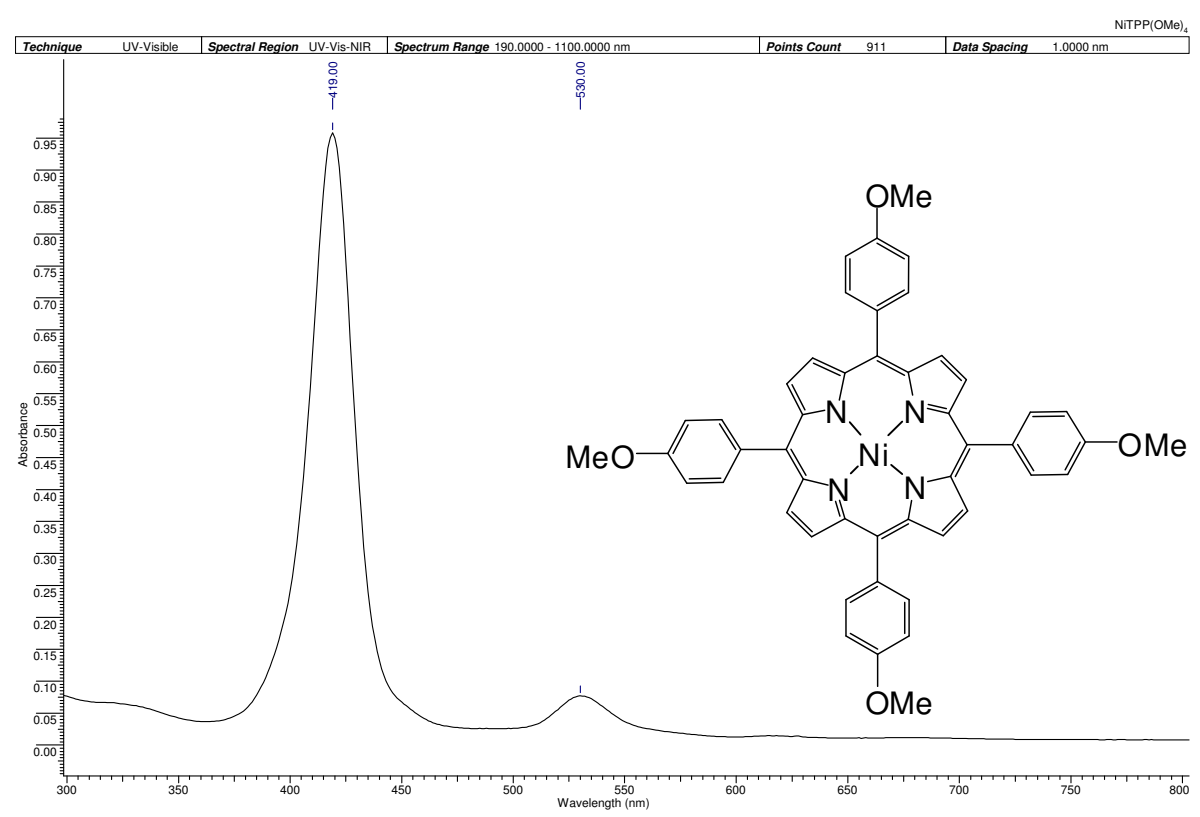

Figura 12: Espectro de UV-VIS do composto 38 em $\mathrm{CHCl3.}$

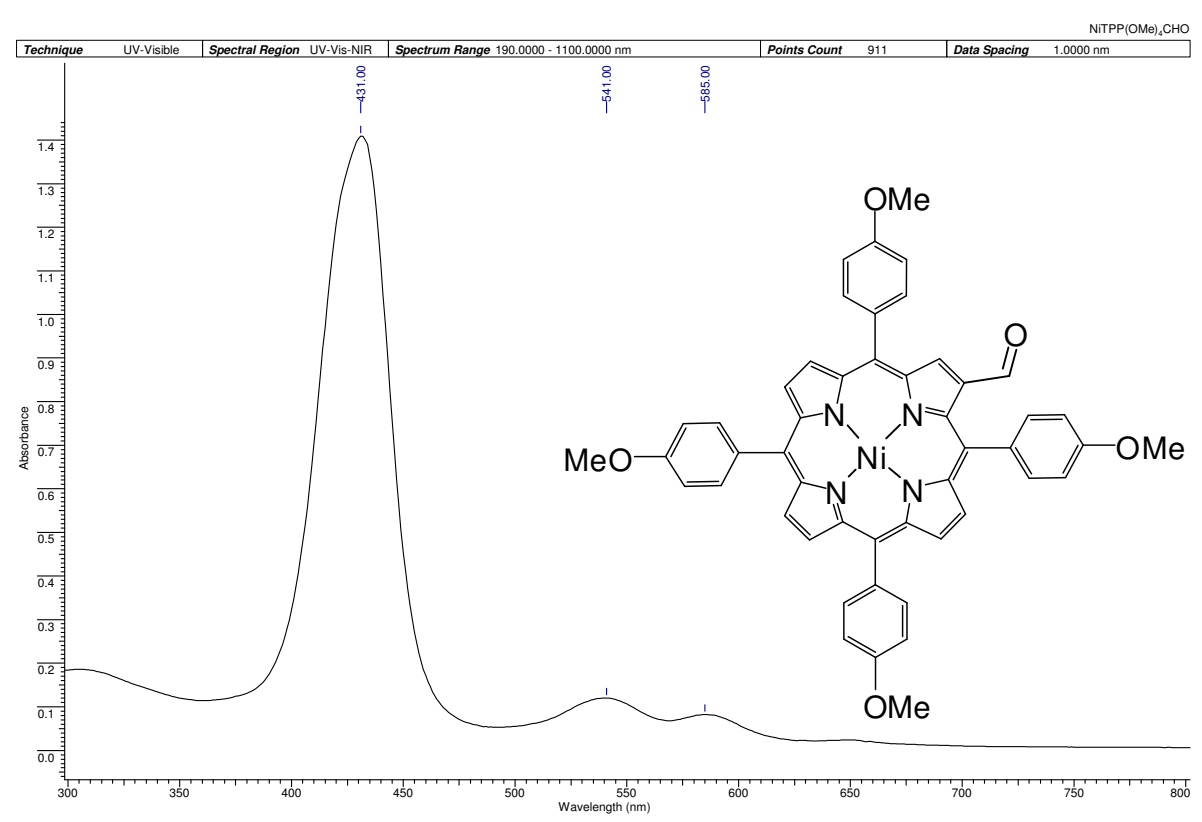

Figura 13: Espectro de UV-VIS do composto $39 \mathrm{em} \mathrm{CHCl}_{3}$. 
7.4 - Preparação da vinil p-tetrametóxifenilporfirina de níquel II.

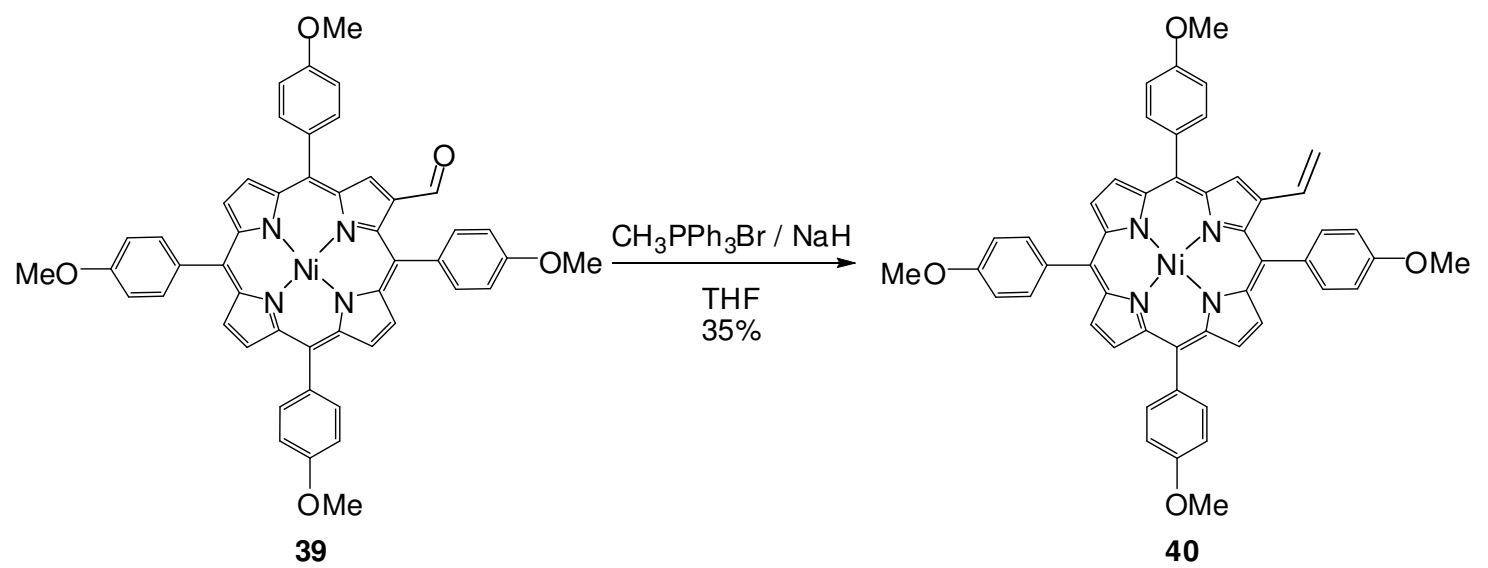

Procedimento: Em um balão de $25 \mathrm{~mL}$ sob atmosfera inerte de $\operatorname{Ar}_{(\mathrm{g})}$ foi adicionado $\mathrm{CH}_{3} \mathrm{PPh}_{3} \mathrm{Br} 98 \%$ (220 mg; 0,60 mmol) e THF (5 mL), mantendo em ultra-som por 10 minutos, deixando em seguida sob agitação por mais 30 minutos. Em seguida foi adicionado NaH 95\% (16 mg; 0,63 mmol), deixando novamente a mistura em ultra-som por 30 minutos, deixando sob agitação por mais 1,5 horas até a solução obter uma coloração amarelada bastante intensa. A essa mistura então foi adicionado 39 na forma sólida (50 mg; $61 \mu \mathrm{mol})$, deixando reagir por 20 minutos (acompanhada por ccd). A reação foi terminada após a adição de $\mathrm{CH}_{2} \mathrm{Cl}_{2}(10 \mathrm{~mL})$ e algumas gotas de água destilada. A mistura final foi extraída com água e a fase orgânica secada com $\mathrm{Na}_{2} \mathrm{SO}_{4}$, filtrada e o solvente eliminando em evaporador rotatório. O resíduo foi então purificado em coluna cromatográfica de sílica-gel, utilizando como eluente $\mathrm{CH}_{2} \mathrm{Cl}_{2}$ :hexano (6:4), sendo que 40 era o produto menos polar.

Rendimento: $17,7 \mathrm{mg}(21,6 \mu \mathrm{mol}) \rightarrow 35 \%$

$\mathrm{RMN}-{ }^{1} \mathrm{H}\left(\mathrm{CDCl}_{3}, 300 \mathrm{MHz}\right) \delta(\mathrm{ppm}): 4,03(2 \mathrm{~s}, 12 \mathrm{H}) ; 5,04\left(\mathrm{dd}, 1 \mathrm{H}, \mathrm{J}_{1}=1,9 ; \mathrm{J}_{2}=10,7\right) ; 5,74$ $\left(\mathrm{dd}, 1 \mathrm{H}, \mathrm{J}_{1}=1,9 ; \mathrm{J}_{2}=17,2\right) ; 6,40\left(\mathrm{dd}, 1 \mathrm{H}, \mathrm{J}_{1}=10,7 ; \mathrm{J}_{2}=17,2\right) ; 7,18(\mathrm{~m}, 8 \mathrm{H}) ; 7,82(\mathrm{~m}, 8 \mathrm{H})$; $8,70(\mathrm{~m}, 6 \mathrm{H}) ; 8,78(\mathrm{~s}, 1 \mathrm{H})$. 


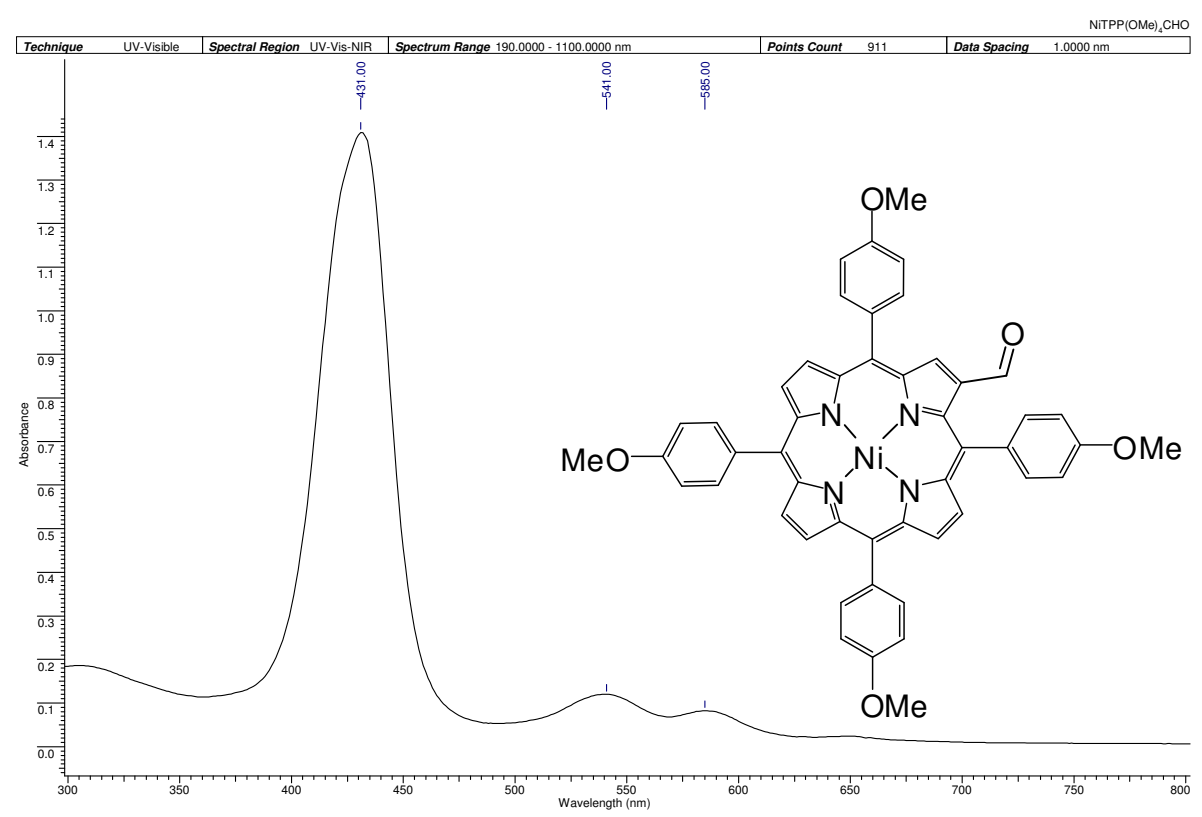

Figura 13: Espectro de UV-VIS do composto $39 \mathrm{em} \mathrm{CHCl}_{3}$.

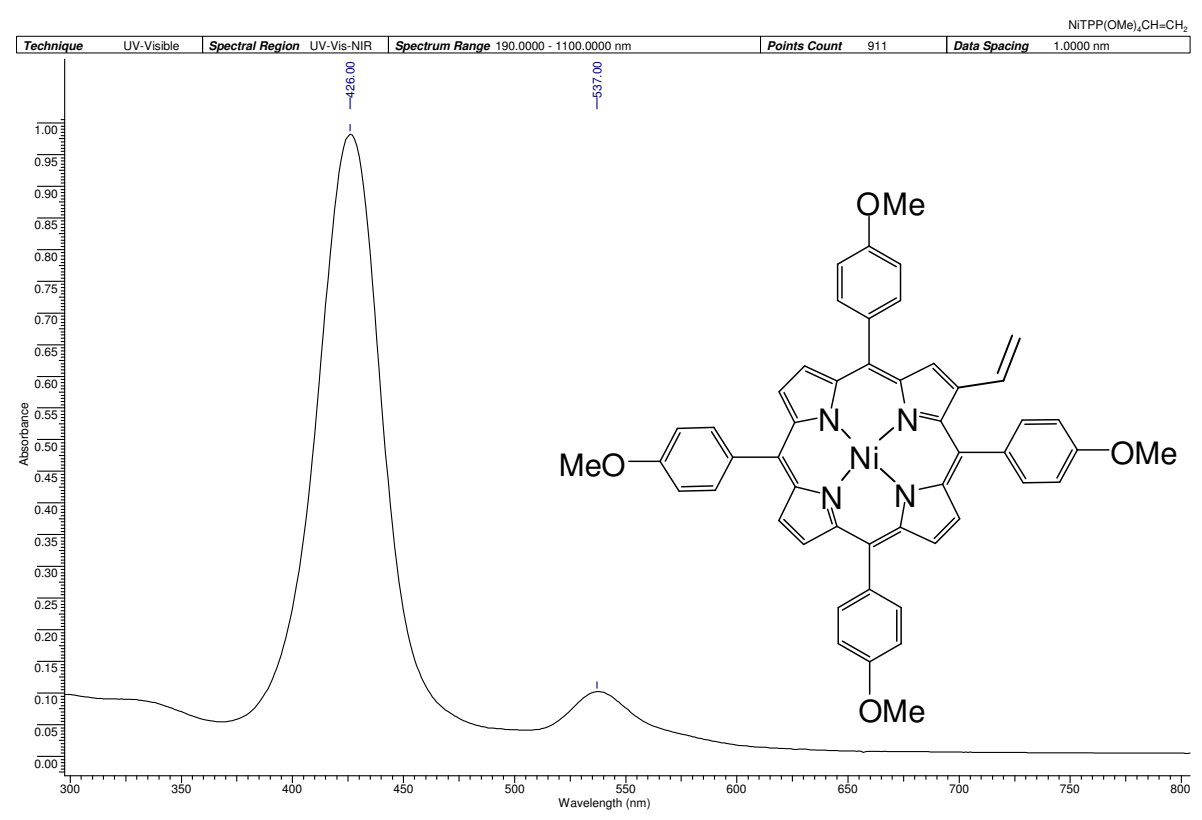

Figura 14: Espectro de UV-VIS do composto $40 \mathrm{em} \mathrm{CHCl}_{3}$. 
7.5 - Preparação da p-tetrahidróxifenilporfirina de níquel II.

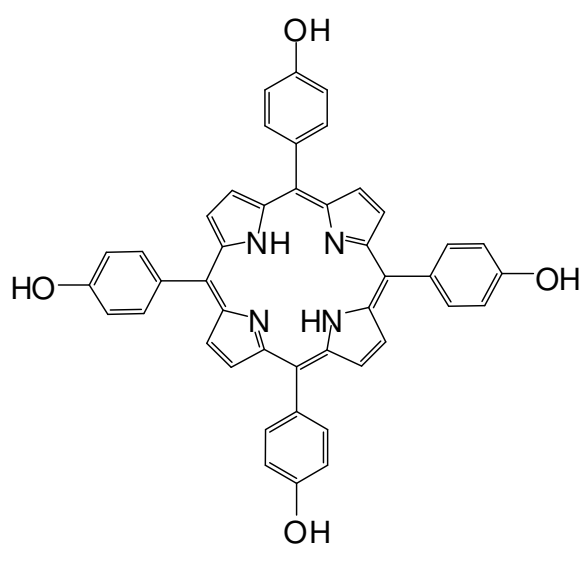

19

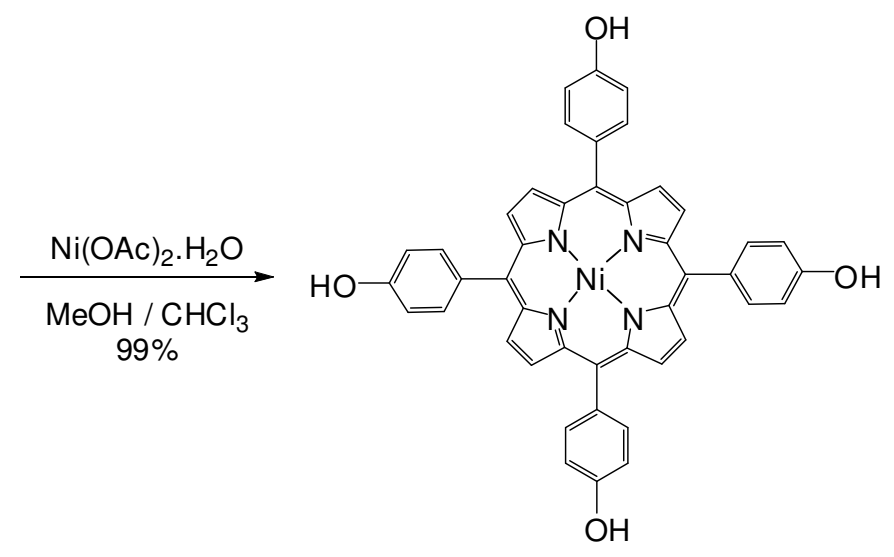

41

Procedimento: A uma solução de $19(10 \mathrm{mg} ; 14,7 \mu \mathrm{mol})$ em $\mathrm{CHCl}_{3}(10 \mathrm{~mL})$ foi adicionada sob agitação a uma solução de $\mathrm{Ni}\left(\mathrm{OAc}_{2} \cdot \mathrm{H}_{2} \mathrm{O}(10 \mathrm{mg} ; 51 \mu \mathrm{mol})\right.$ em MeOH $(8 \mathrm{~mL})$ e a mistura foi mantida a refluxo por 2 dias. Ao término da reação (acompanhada por ccd), o solvente foi removido em evaporador rotatório e o produto residual purificado em coluna cromatográfica de sílica-gel, utilizando como eluente uma mistura de $\mathrm{CH}_{2} \mathrm{Cl}_{2}: \mathrm{MeOH}(8: 2)$. As alíquotas referentes a 41 foram reunidas e o solvente removido a vácuo.

Rendimento: $10,6 \mathrm{mg}(14,5 \mu \mathrm{mol}) \rightarrow 99 \%$

RMN- ${ }^{1} \mathrm{H}\left(\mathrm{CD}_{3} \mathrm{OD}, 400 \mathrm{MHz}\right) \delta(\mathrm{ppm}): 7,11$ (d, 8H. J= Hz); 7,76 (d, 8H, J= Hz); 8,70 (s, 8H). $\mathrm{RMN}-{ }^{13} \mathrm{C}\left(\mathrm{CD}_{3} \mathrm{OD}, 100 \mathrm{MHz}\right) \delta(\mathrm{ppm}): 114,8(\mathrm{CH}) ; 120,4(\mathrm{C}) ; 132,7(\mathrm{CH}) ; 133,4(\mathrm{C}) ; 136,0$ $(\mathrm{CH}) ; \quad 144,6$ (C); 158,6 (C). MS-ESI-TOF: $\mathrm{C}_{44} \mathrm{H}_{29} \mathrm{~N}_{4} \mathrm{NiO}_{4}^{+}(\mathrm{MH})^{+}$esperado 735,1537; encontrado 735,1659 . 


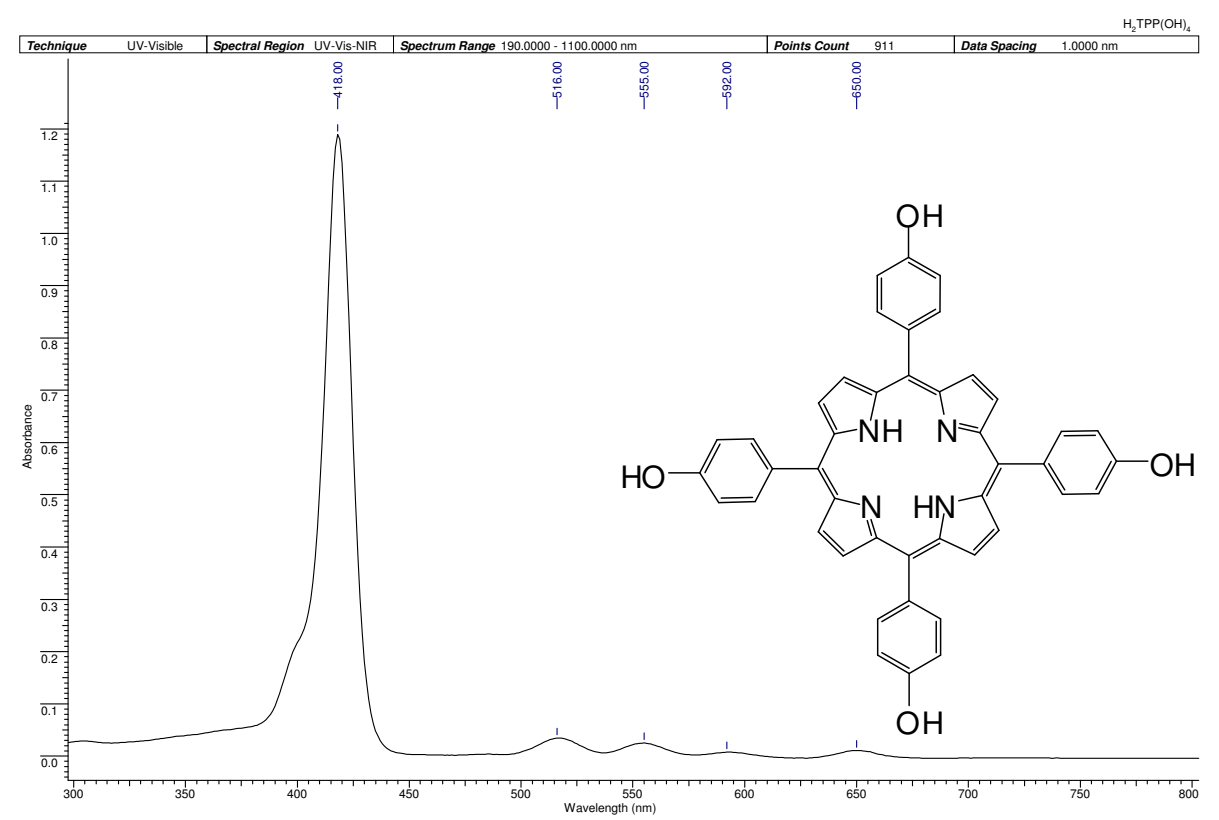

Figura 15: Espectro de UV-VIS do composto $19 \mathrm{em} \mathrm{MeOH}$.

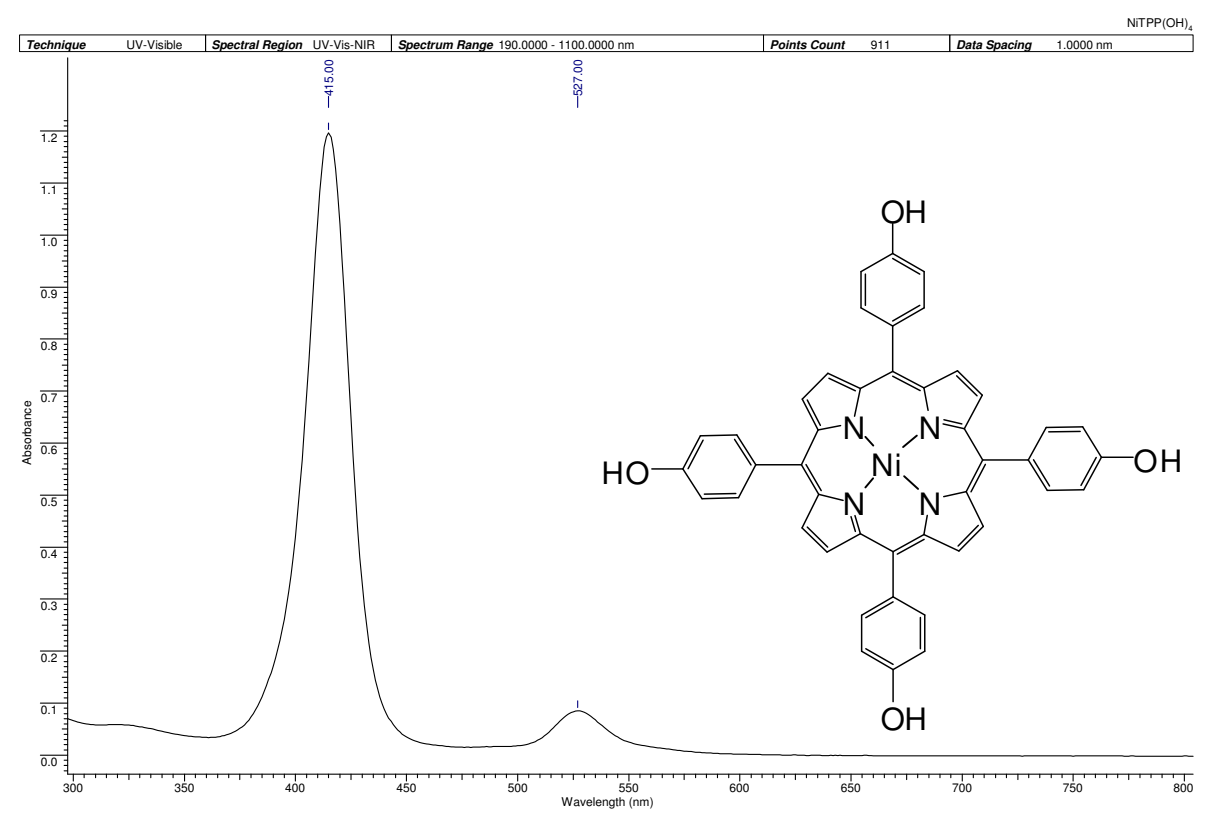

Figura 16: Espectro de UV-VIS do composto $41 \mathrm{em} \mathrm{CHCl}_{3}$. 
7.6 - Preparação da p-tetraacetóxifenilporfirina de níquel II.

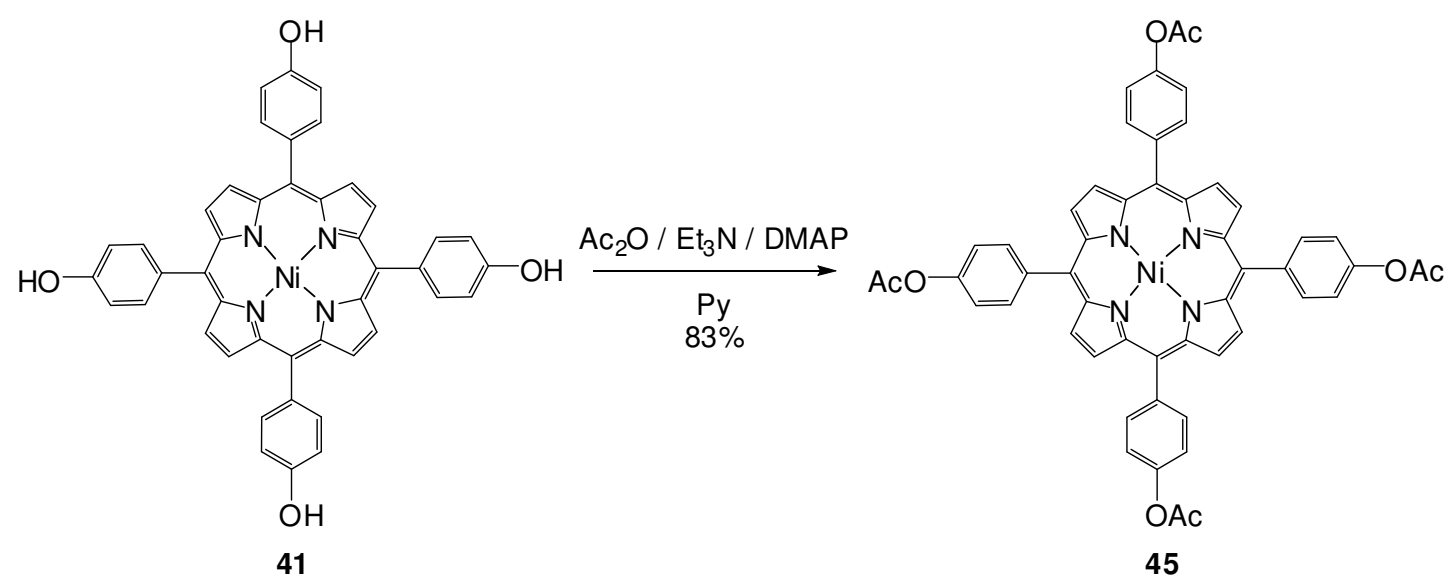

Procedimento: Em um balão sob atmosfera de argônio e a $0^{\circ} \mathrm{C}$ foram misturados $\mathrm{Ac}_{2} \mathrm{O}$ (103,5 $\mu \mathrm{L} ; 116 \mathrm{mg} ; 1,09 \mathrm{mmol})$ em $\mathrm{Et}_{3} \mathrm{~N}(153 \mu \mathrm{L} ; 111 \mathrm{mg} ; 1,10 \mathrm{mmol})$. Em seguida, adicionouse 41 (135 mg; 0,18 mmol) em piridina $(2,0 \mathrm{~mL})$ juntamente com quantidades catalíticas de DMAP. A reação foi mantida a $0^{\circ} \mathrm{C}$ por 30 minutos e em seguida a temperatura ambiente por mais 12 horas. Ao final do consumo do material de partida, a reação foi terminada com a adição de solução saturada de $\mathrm{NaCl}$ e extração $\operatorname{com} \mathrm{CHCl}_{3}(3$ x 20mL). A fase orgânica foi então seca com $\mathrm{Na}_{2} \mathrm{SO}_{4}$, filtrada e o solvente removido em evaporador rotatório. $\mathrm{O}$ produto resultante foi purificado em coluna cromatográfica de sílica-gel utilizando como eluente uma mistura de $\mathrm{CH}_{2} \mathrm{Cl}_{2}: \mathrm{MeOH}$ (9:1). As alíquotas contendo 45 foram reunidas e o solvente evaporado a vácuo.

Rendimento: $138,4 \mathrm{mg}(0,153 \mathrm{mmol}) \rightarrow 83 \%$

$\mathrm{RMN}-{ }^{1} \mathrm{H}\left(\mathrm{CDCl}_{3}, 400 \mathrm{MHz}\right) \delta$ (ppm): 2,46 (s, 12H); 7,11 (d, 8H. J= 8,3Hz); 7,76 (d, 8H, J= $8,3 \mathrm{~Hz}) ; 8,77$ (s, 8H). RMN- ${ }^{13} \mathrm{C}\left(\mathrm{CDCl}_{3}, 100 \mathrm{MHz}\right) \delta(\mathrm{ppm}): 21,3\left(\mathrm{CH}_{3}\right) ; 118,1(\mathrm{C}) ; 120,0$ $(\mathrm{CH}) ; 132,3(\mathrm{CH}) ; 134,5(\mathrm{CH}) ; 138,6(\mathrm{C}) ; 142,7(\mathrm{C}) ; 150,6(\mathrm{C}) ; 169,5$ (C=O éster). MS-ESITOF: $\mathrm{C}_{52} \mathrm{H}_{37} \mathrm{~N}_{4} \mathrm{NiO}_{8}^{+}(\mathrm{MH})^{+}$esperado 903,1959; encontrado 903,2072. 


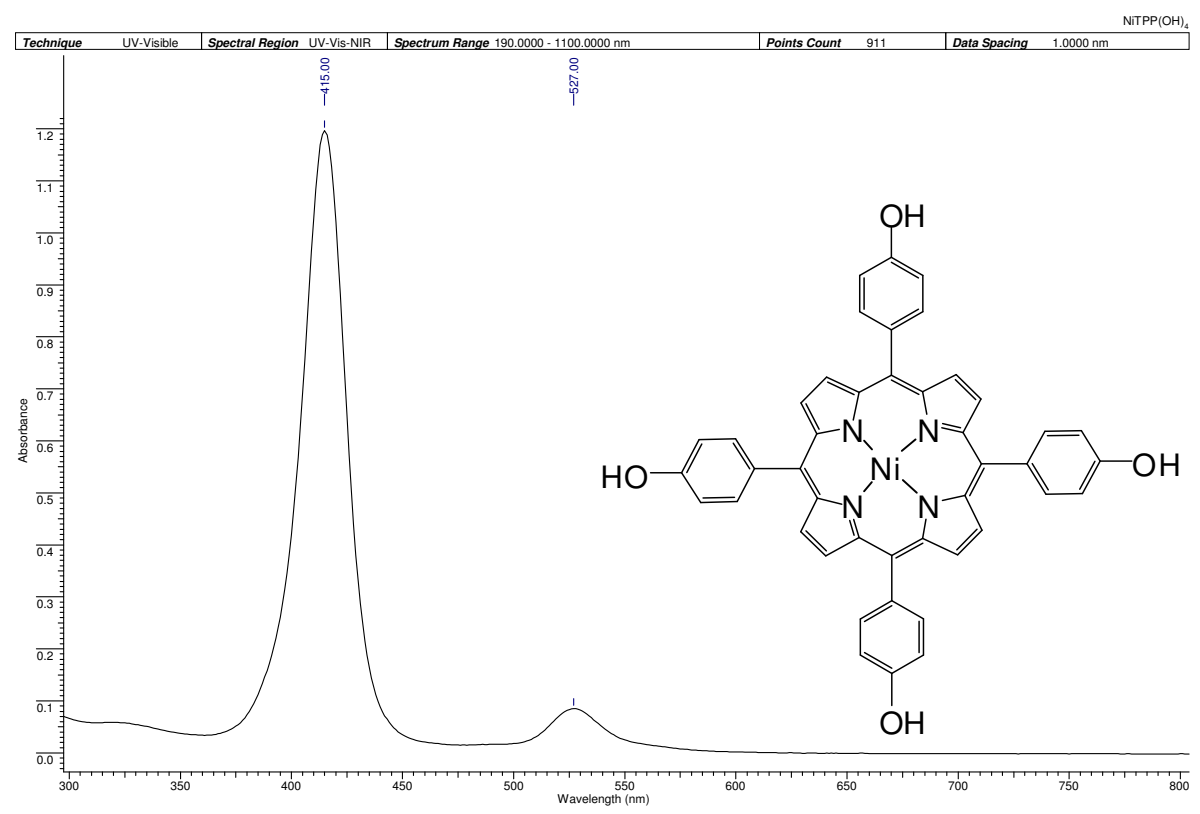

Figura 16: Espectro de UV-VIS do composto $41 \mathrm{em} \mathrm{CHCl}_{3}$.

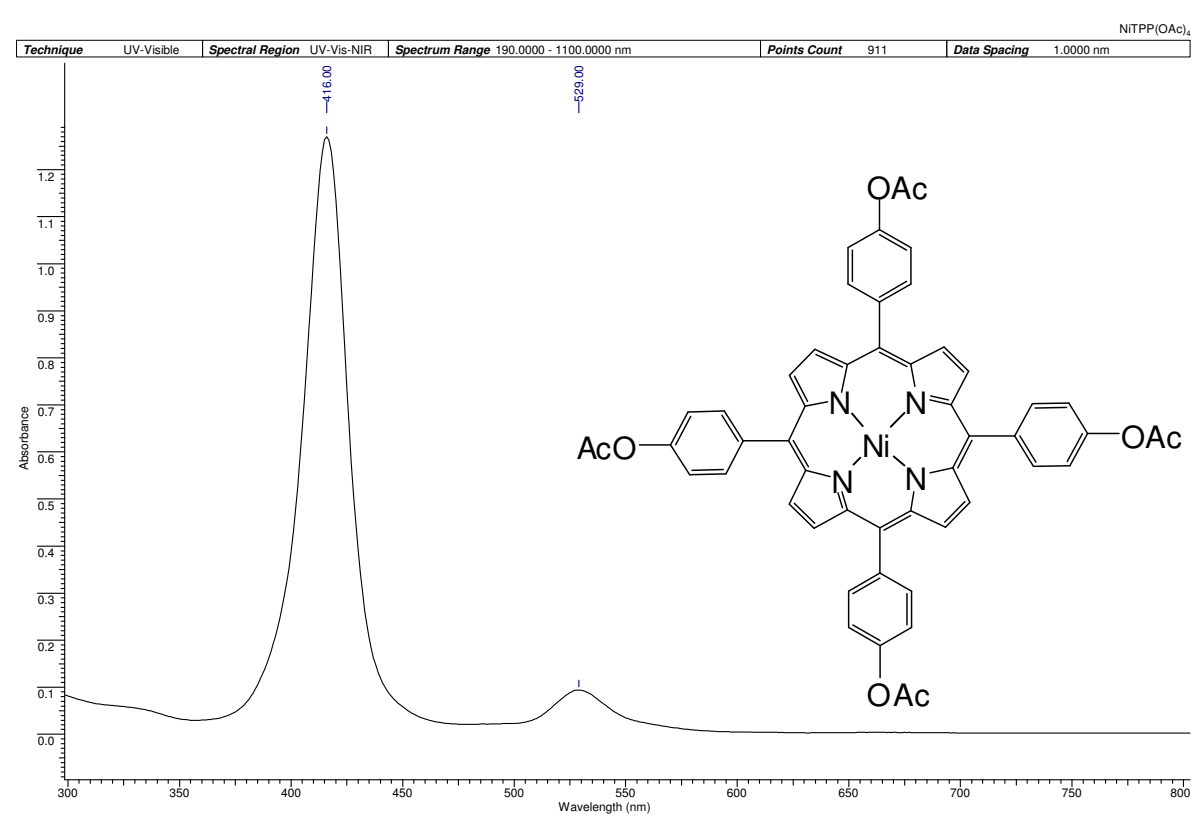

Figura 17: Espectro de UV-VIS do composto $45 \mathrm{em} \mathrm{CHCl}_{3}$. 
7.7 - Preparação da formil p-tetraacetóxifenilporfirina de níquel II.

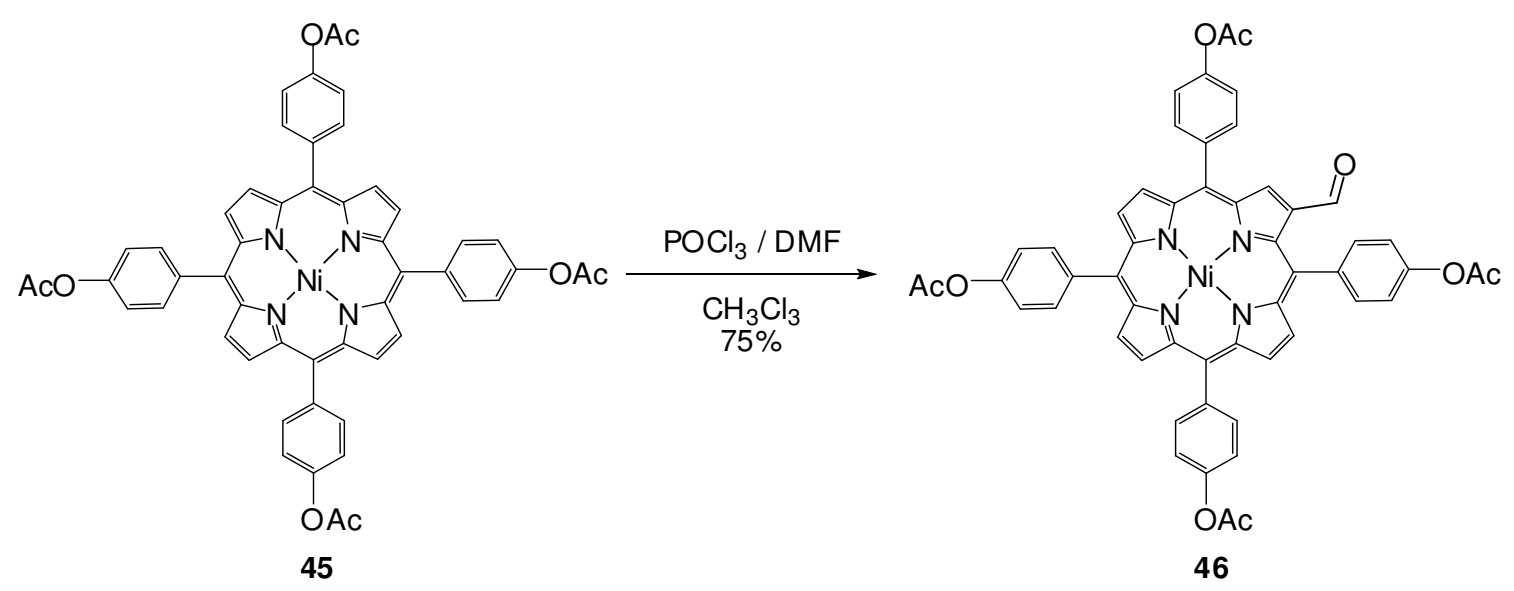

Procedimento: $\mathrm{O}$ complexo de Vilsmeier foi preparado a partir da adição de $\mathrm{POCl}_{3}$ (1,0 mL; 10,7 mmol) em DMF (1,2 mL; $15.5 \mathrm{mmol})$ sob atmosfera de argônio. O complexo formado foi mantido sob agitação vigorosa a temperatura ambiente por 30 minutos. Em seguida, sob resfriamento $\left(0^{\circ} \mathrm{C}\right)$, adicionou-se lentamente 45 (138,4 $\left.\mathrm{mg} ; 0,153 \mathrm{mmol}\right)$ dissolvida em $\mathrm{CHCl}_{3}$ seco $(10 \mathrm{~mL})$ e a solução resultante foi mantida a refluxo por 12 horas. Após o período descrito, o recipiente reacional foi resfriado (banho de gelo), adicionou-se solução saturada de $\mathrm{NaOAc}$ para elevar o $\mathrm{pH}$ da mistura ( $\mathrm{pH}$ 9-10), separou-se a fase orgânica e a fase aquosa foi extraída com $\mathrm{CHCl}_{3}(3 \times 30 \mathrm{~mL})$. A fase orgânica foi seca com $\mathrm{Na}_{2} \mathrm{SO}_{4}$, filtrada e o solvente removido em evaporador rotatório. O resíduo foi então purificado em coluna cromatográfica de sílica-gel, utilizando como eluente $\mathrm{CH}_{2} \mathrm{Cl}_{2}$ :EtOAc (9:1).

Rendimento: $106,9 \mathrm{mg}(0,115 \mathrm{mmol}) \rightarrow 75 \%$

RMN- ${ }^{1} \mathrm{H}\left(\mathrm{CDCl}_{3}, 300 \mathrm{MHz}\right) \delta(\mathrm{ppm}):$ 2,44 (s, 3H); 2,46 (s, 9H); 7,45 (m, 8H); 7,97 (m, 8H); 8,73 (m, 6H); 9,30 (s, 1H); 9,31 (s, 1H). RMN- ${ }^{13} \mathrm{C}\left(\mathrm{CDCl}_{3}, 75,5 \mathrm{MHz}\right) \delta(\mathrm{ppm}): 21,3\left(\mathrm{CH}_{3}\right)$; 120,3 (CH); 120,7 (C); 134,4 (CH); 134,5 (CH); 134,7 (CH); 137,6 (C). MS-ESI-TOF: $\mathrm{C}_{53} \mathrm{H}_{37} \mathrm{~N}_{4} \mathrm{NiO}_{9}{ }^{+}(\mathrm{MH})^{+}$esperado 931,1909; encontrado 931,1938. 


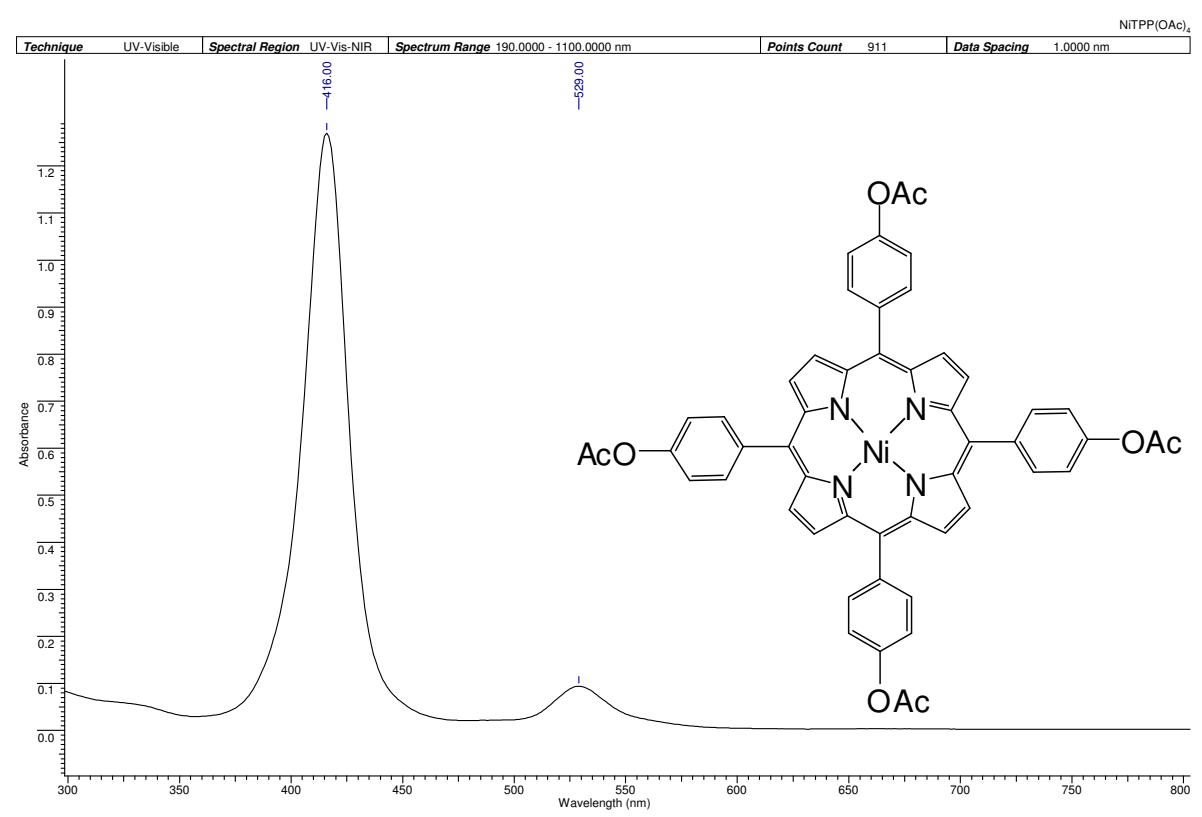

Figura 17: Espectro de UV-VIS do composto $45 \mathrm{em} \mathrm{CHCl}_{3}$.

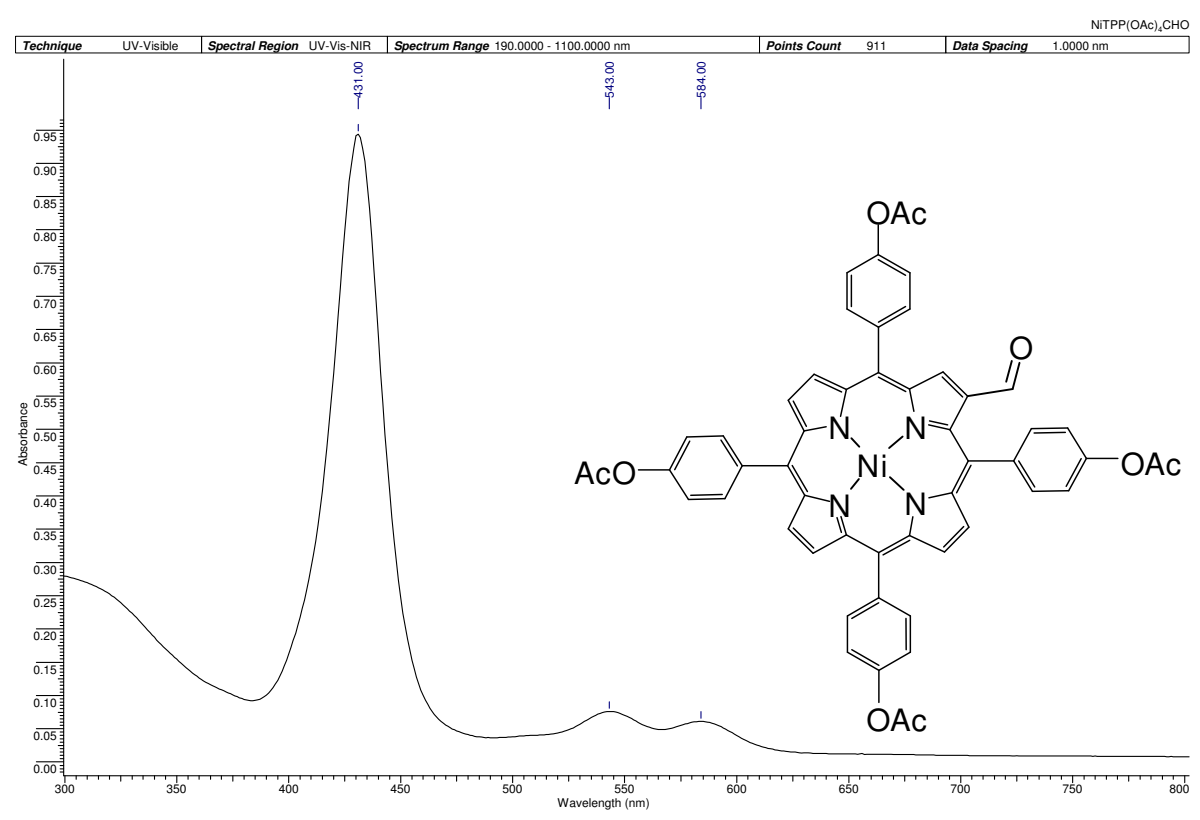

Figura 18: Espectro de UV-VIS do composto $46 \mathrm{em} \mathrm{CHCl}_{3}$. 
7.8 - Preparação da vinil p-tetraacetóxifenilporfirina de níquel II.

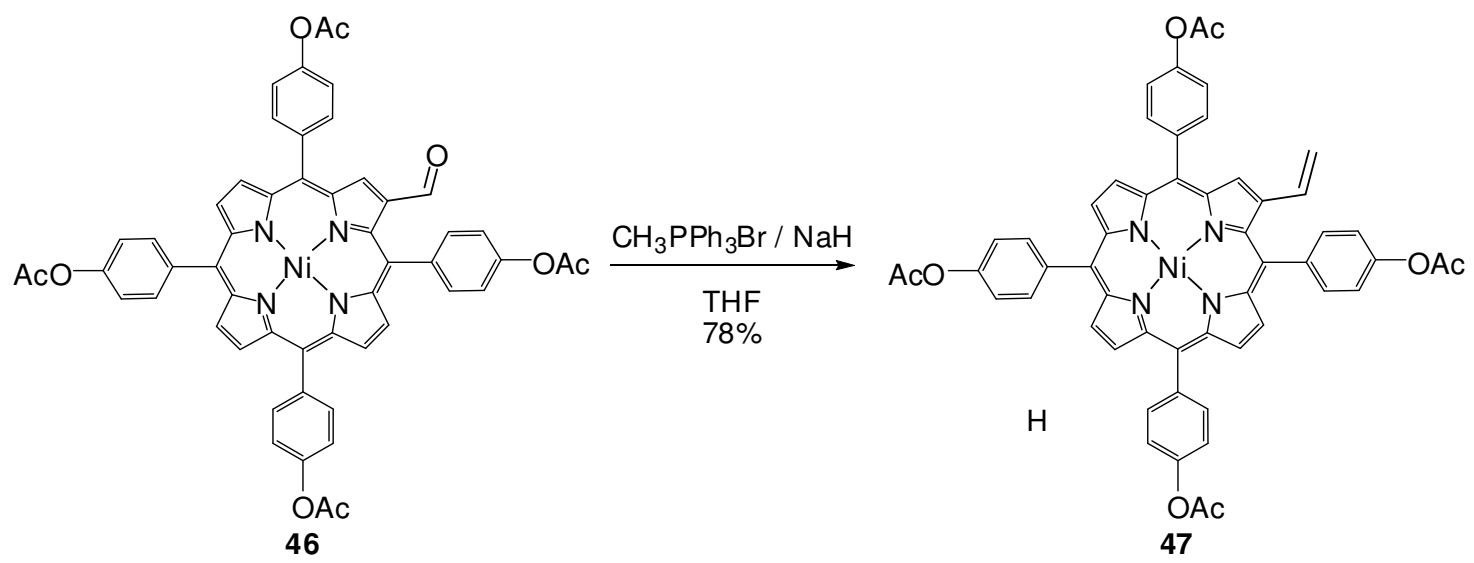

Procedimento: Em um balão de $25 \mathrm{~mL}$ sob atmosfera de $\operatorname{Ar}_{(\mathrm{g})}$ foi adicionado $\mathrm{CH}_{3} \mathrm{PPh}_{3} \mathrm{Br} 97 \%$ (210 mg, 0,57 mmol) e THF (7 mL), mantendo em ultra-som por 10 minutos, deixando em seguida sob agitação por mais 30 minutos. Em seguida foi adicionado NaH 95\% (14 mg, 0,55 mmol), deixando novamente a mistura em ultra-som por 30 minutos, deixando sob agitação por mais 1,5 horas até a solução obter uma coloração amarelada bastante intensa. A essa mistura então foi adicionado 46 na forma sólida (52,4 mg; 56,2 $\mu \mathrm{mol})$, deixando reagir por 5 minutos (acompanhada por ccd). A reação foi terminada após a adição de $\mathrm{CH}_{2} \mathrm{Cl}_{2}(10$ $\mathrm{mL}$ ) e algumas gotas de água destilada. A mistura final foi extraída com água e a fase orgânica seca com $\mathrm{Na}_{2} \mathrm{SO}_{4}$, filtrada e o solvente eliminando em evaporador rotatório. $\mathrm{O}$ resíduo foi então purificado em coluna cromatográfica de sílica-gel, utilizando como eluente $\mathrm{CH}_{2} \mathrm{Cl}_{2}$ :hexano:EtOAc (4:3:3), sendo que 47 era o produto menos polar.

Rendimento: $25,0 \mathrm{mg}(26,9 \mu \mathrm{mol}) \rightarrow 48 \%$

$\mathrm{RMN}-{ }^{1} \mathrm{H}\left(\mathrm{CDCl}_{3}, 300 \mathrm{MHz}\right) \delta(\mathrm{ppm}): 2,45(\mathrm{~s}, 12 \mathrm{H}) ; 5,08\left(\mathrm{dd}, 1 \mathrm{H}, J_{1}=1,7 \mathrm{~Hz}, J_{2}=11,0 \mathrm{~Hz}\right) ; 5,74$ (dd, $\left.1 \mathrm{H}, J_{1}=1,7 \mathrm{~Hz}, J_{2}=17,1 \mathrm{~Hz}\right) ; 6,35\left(\mathrm{dd}, 1 \mathrm{H}, J_{1}=11,0 \mathrm{~Hz}, J_{2}=17,1 \mathrm{~Hz}\right) ; 7,39(\mathrm{~m}, 8 \mathrm{H}) ; 7,92(\mathrm{~m}$, $8 \mathrm{H}) ; 8,72(\mathrm{~m}, 7 \mathrm{H}) . \mathrm{RMN}-{ }^{13} \mathrm{C}\left(\mathrm{CDCl}_{3}, 75,5 \mathrm{MHz}\right) \delta(\mathrm{ppm}): 21,3\left(\mathrm{CH}_{3}\right) ; 115,4\left(\mathrm{CH}_{2}\right) ; 120,1$ $(\mathrm{CH}) ; 132,6(\mathrm{CH}) ; 134,5(\mathrm{CH}) ; 150,6(\mathrm{C}) ; 169,5$ (C=O éster). MS-ESI-TOF: $\mathrm{C}_{54} \mathrm{H}_{39} \mathrm{~N}_{4} \mathrm{NiO}_{8}{ }^{+}$ $(\mathrm{MH})^{+}$esperado 929,2116; encontrado 929,2265. 


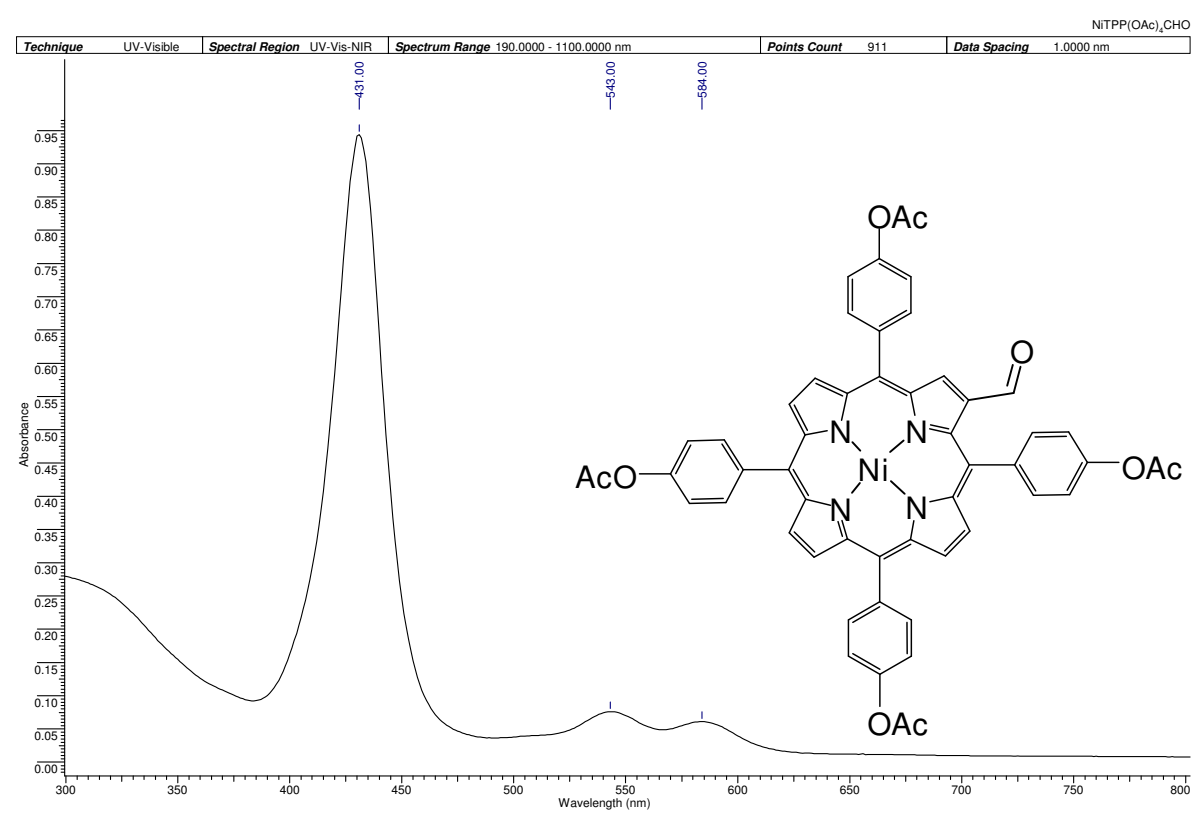

Figura 18: Espectro de UV-VIS do composto $46 \mathrm{em} \mathrm{CHCl}_{3}$.

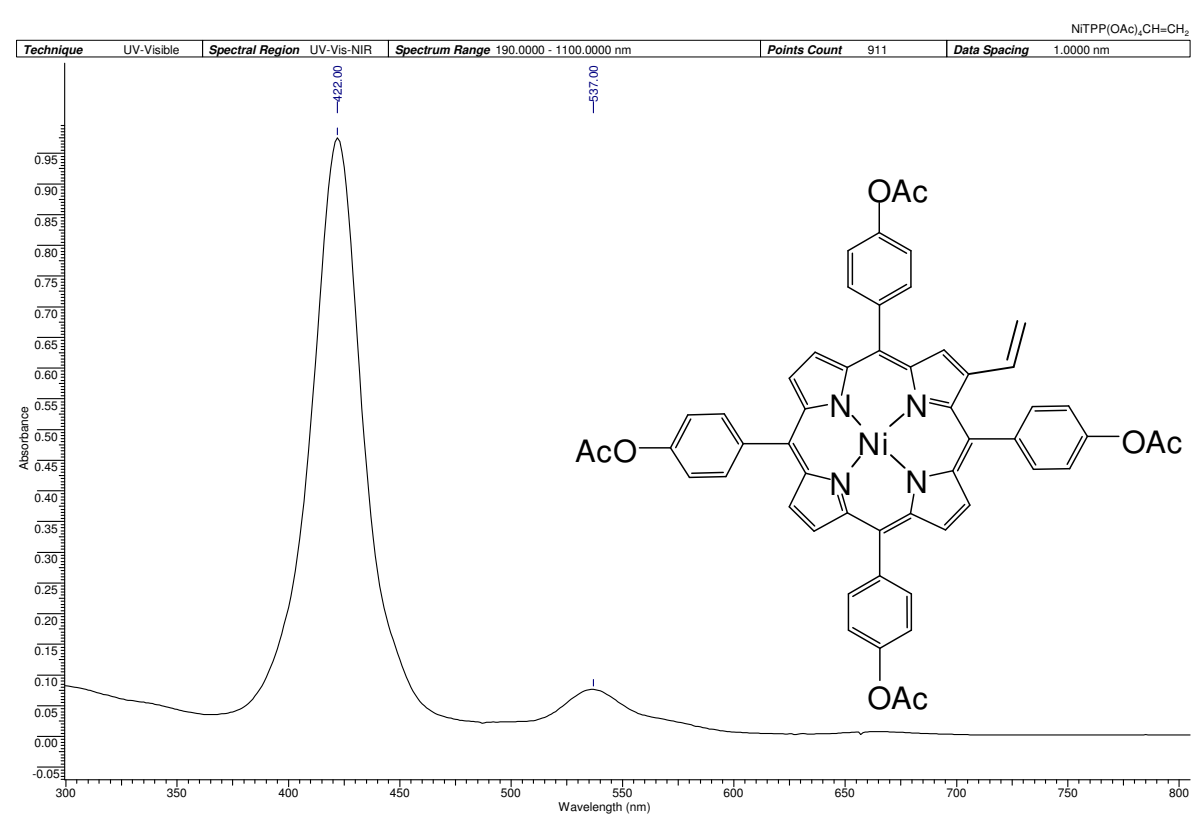

Figura 19: Espectro de UV-VIS do composto $47 \mathrm{em} \mathrm{CHCl}_{3}$. 
7.9 - Preparação da vinil p-tetrahidróxifenilporfirina de níquel II.
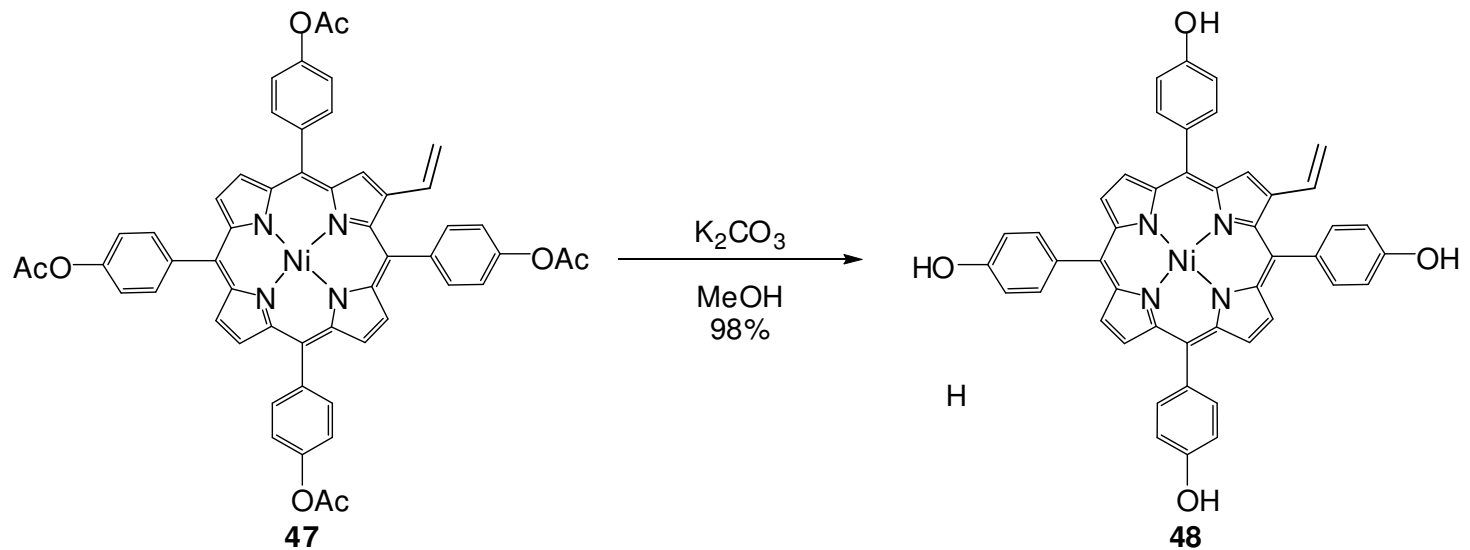

Procedimento: Em um balão foram misturados 47 (7,5 $\mathrm{mg} ; 8,1 \mu \mathrm{mol})$ e solução saturada de $\mathrm{K}_{2} \mathrm{CO}_{3}$ em MeOH (2 mL), mantendo a temperatura ambiente. Após o período de 10 minutos, verificou-se que todo o material de partida havia se convertido integralmente em um único produto (por ccd). O solvente foi removido a vácuo e o resíduo extraído com $\mathrm{CHCl}_{3}$ e água. Novamente o solvente foi evaporado e 48 foi obtido com um bom rendimento.

Rendimento: $6,0 \mathrm{mg}(7,9 \mu \mathrm{mol}) \rightarrow 98 \%$

$\mathrm{RMN}-{ }^{1} \mathrm{H}\left(\mathrm{CD}_{3} \mathrm{OD}, 500 \mathrm{MHz}\right) \delta(\mathrm{ppm}): 5,32\left(\mathrm{dd}, 1 \mathrm{H}, J_{1}=1,4 \mathrm{~Hz}, J_{2}=10,5 \mathrm{~Hz}\right) ; 5,64(\mathrm{dd}, 1 \mathrm{H}$, $\left.J_{1}=1,4 \mathrm{~Hz}, J_{2}=16,7 \mathrm{~Hz}\right) ; 6,32\left(\mathrm{dd}, 1 \mathrm{H}, J_{1}=10,5 \mathrm{~Hz}, J_{2}=16,7 \mathrm{~Hz}\right) ; 7,05(\mathrm{~m}, 8 \mathrm{H}) ; 7,57(\mathrm{~m}, 8 \mathrm{H}) ; 8,56$ (m, 7H). RMN- ${ }^{13} \mathrm{C}\left(\mathrm{CDCl}_{3}, 125 \mathrm{MHz}\right) \delta(\mathrm{ppm}): 64,2\left(\right.$ cis- $\left.\mathrm{CH}_{2}\right) ; 114,1\left(\right.$ trans $\left.-\mathrm{CH}_{2}\right) ; 114,2(\mathrm{CH})$; 114,7 (CH); 132,4 (CH); 136,5 (CH). MS-ESI-TOF: $\mathrm{C}_{46} \mathrm{H}_{31} \mathrm{~N}_{4} \mathrm{NiO}_{4}^{+}(\mathrm{MH})^{+}$esperado 761,1693; encontrado 761,1713. 


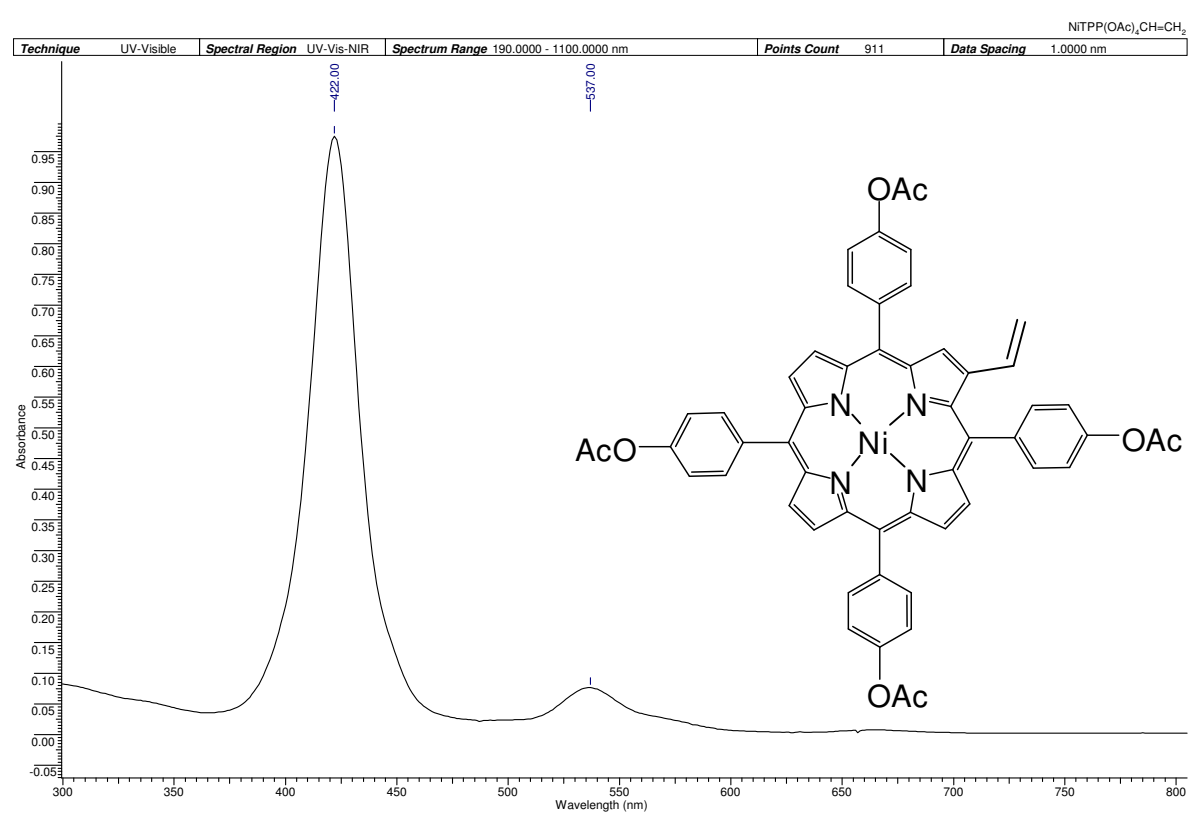

Figura 19: Espectro de UV-VIS do composto $47 \mathrm{em} \mathrm{CHCl}_{3}$.

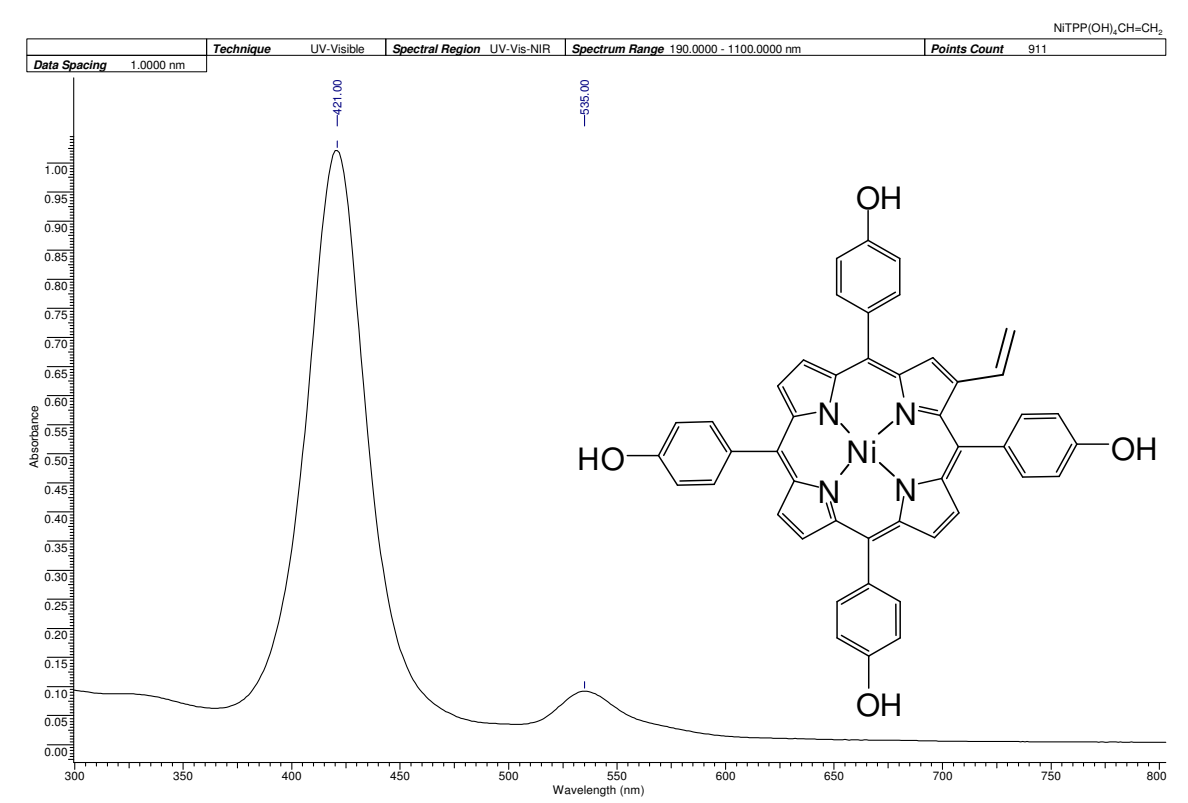

Figura 20: Espectro de UV-VIS do composto 48 em $\mathrm{MeOH}$. 


\section{Espectros de Ressonância Magnética Nuclear}




\section{8 - Espectros de RMN.}

Nesta seção serão apresentados os espectros de RMN de ${ }^{1} \mathrm{H}$ e ${ }^{13} \mathrm{C}$ dos compostos deste trabalho. Também serão incluídas algumas tabelas de atribuição contendo dados obtidos pelas técnicas de correlação gCOSY, gHMQC, gHMBC. Todos os espectros foram visualizados pelo "software" da Bruker (WINNMR - NMR). 


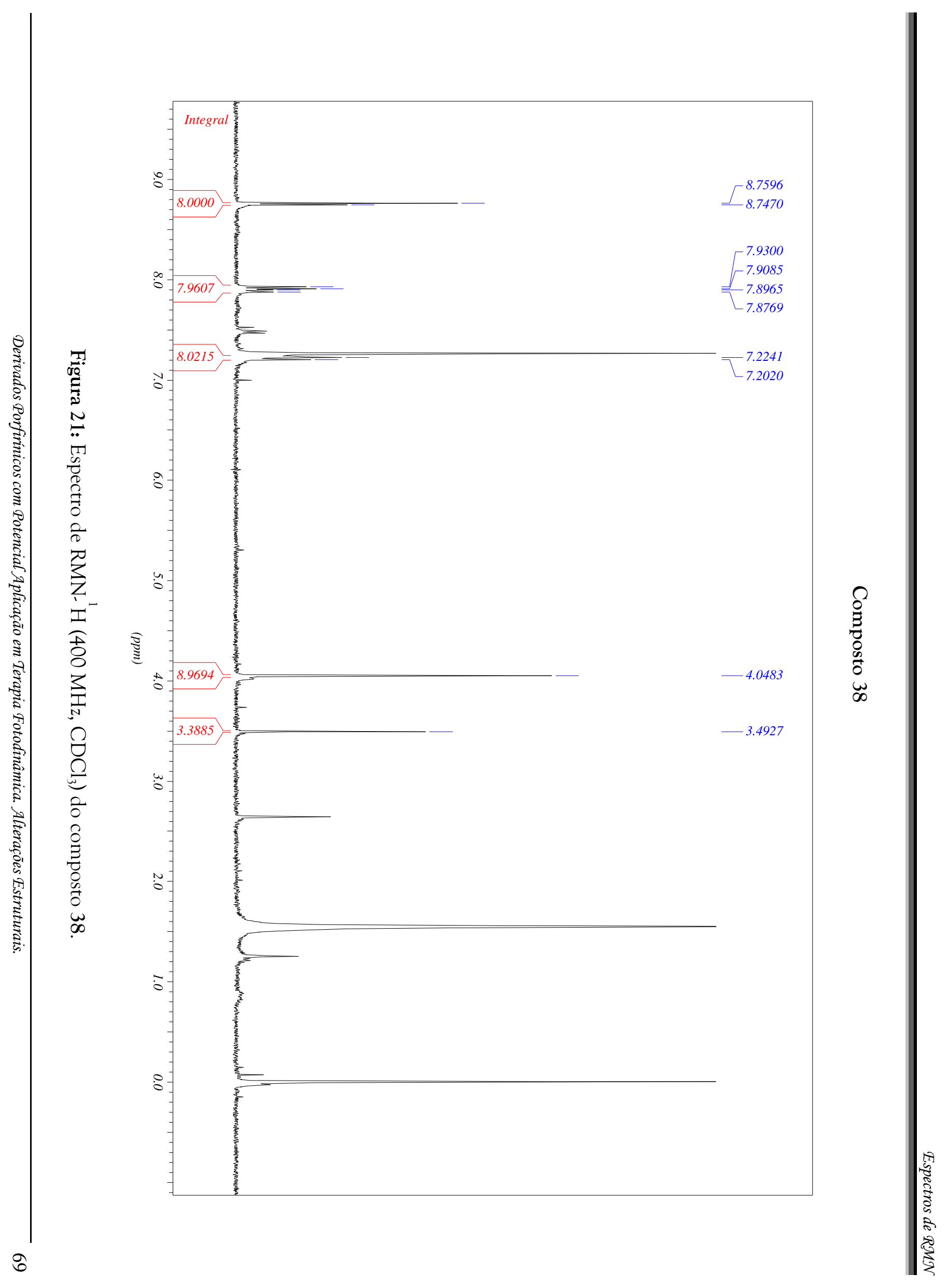




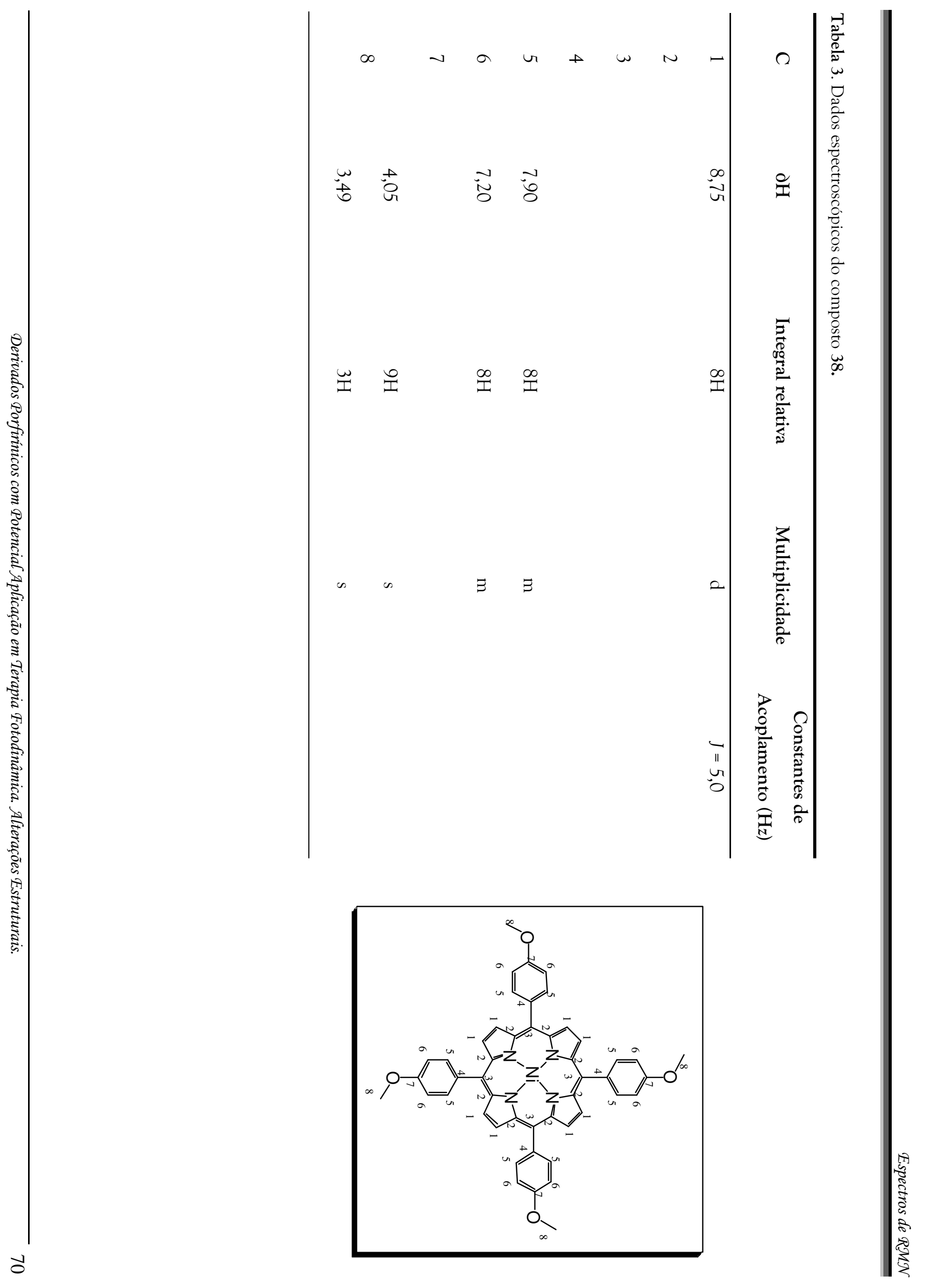




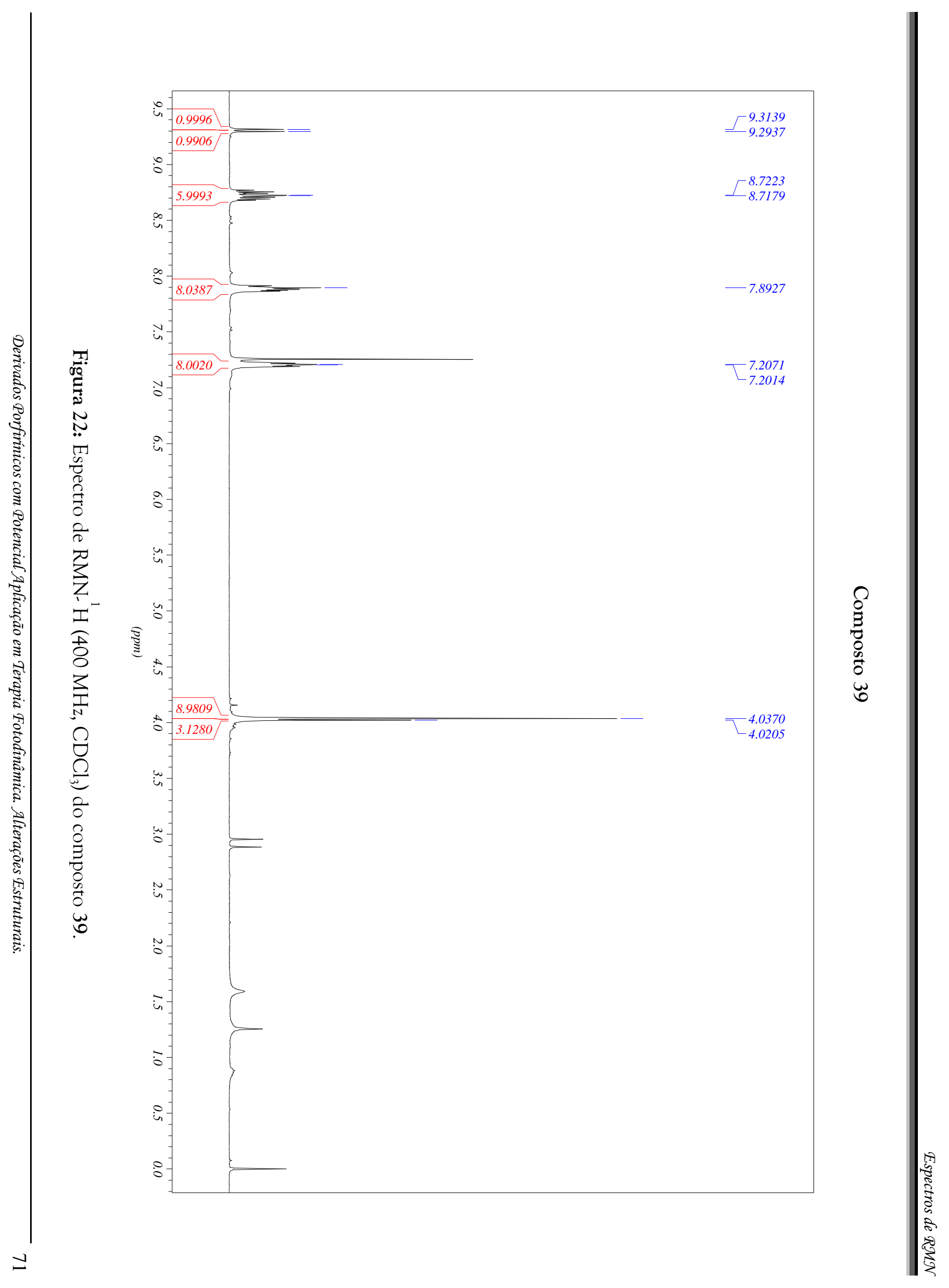




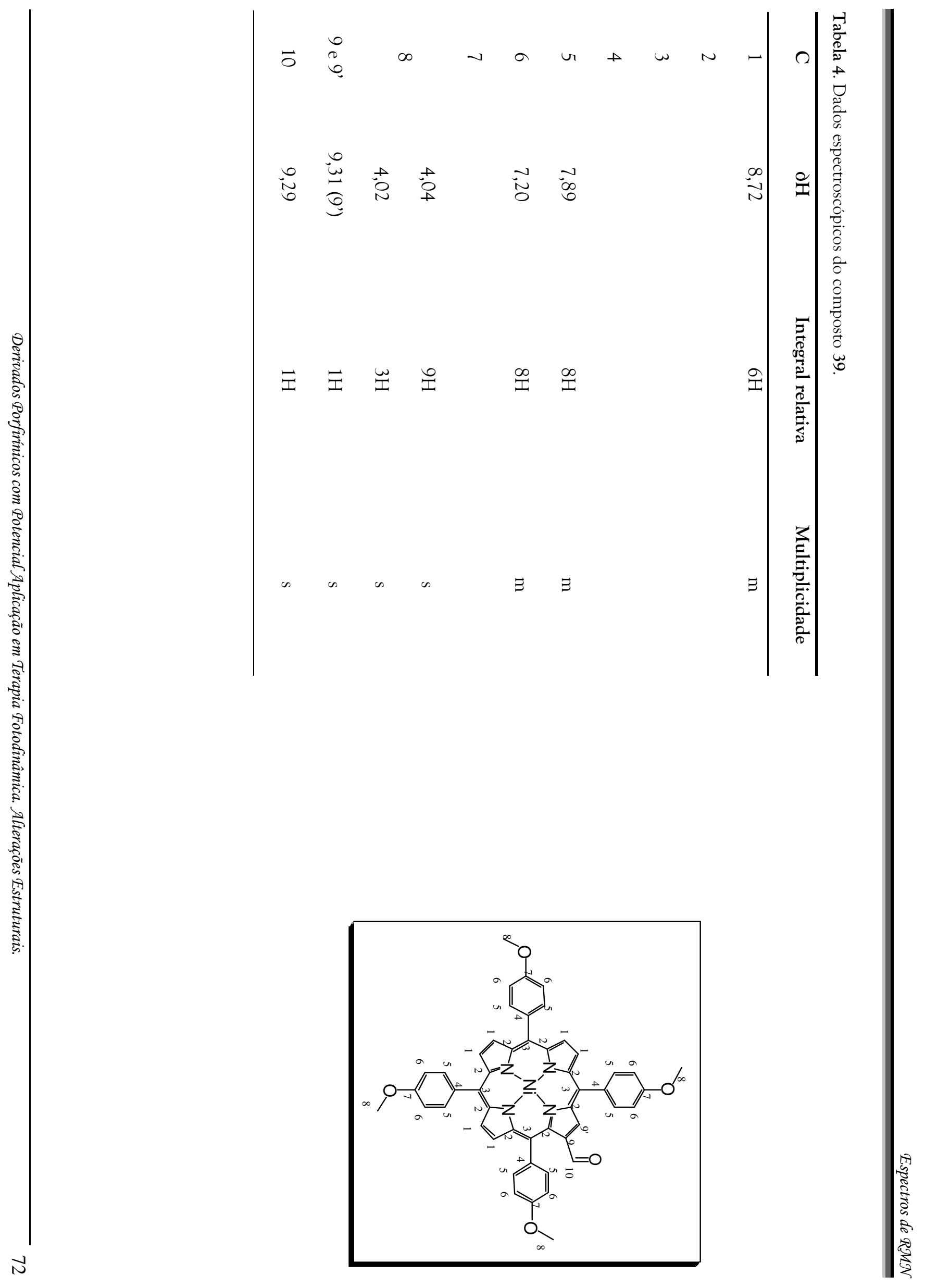




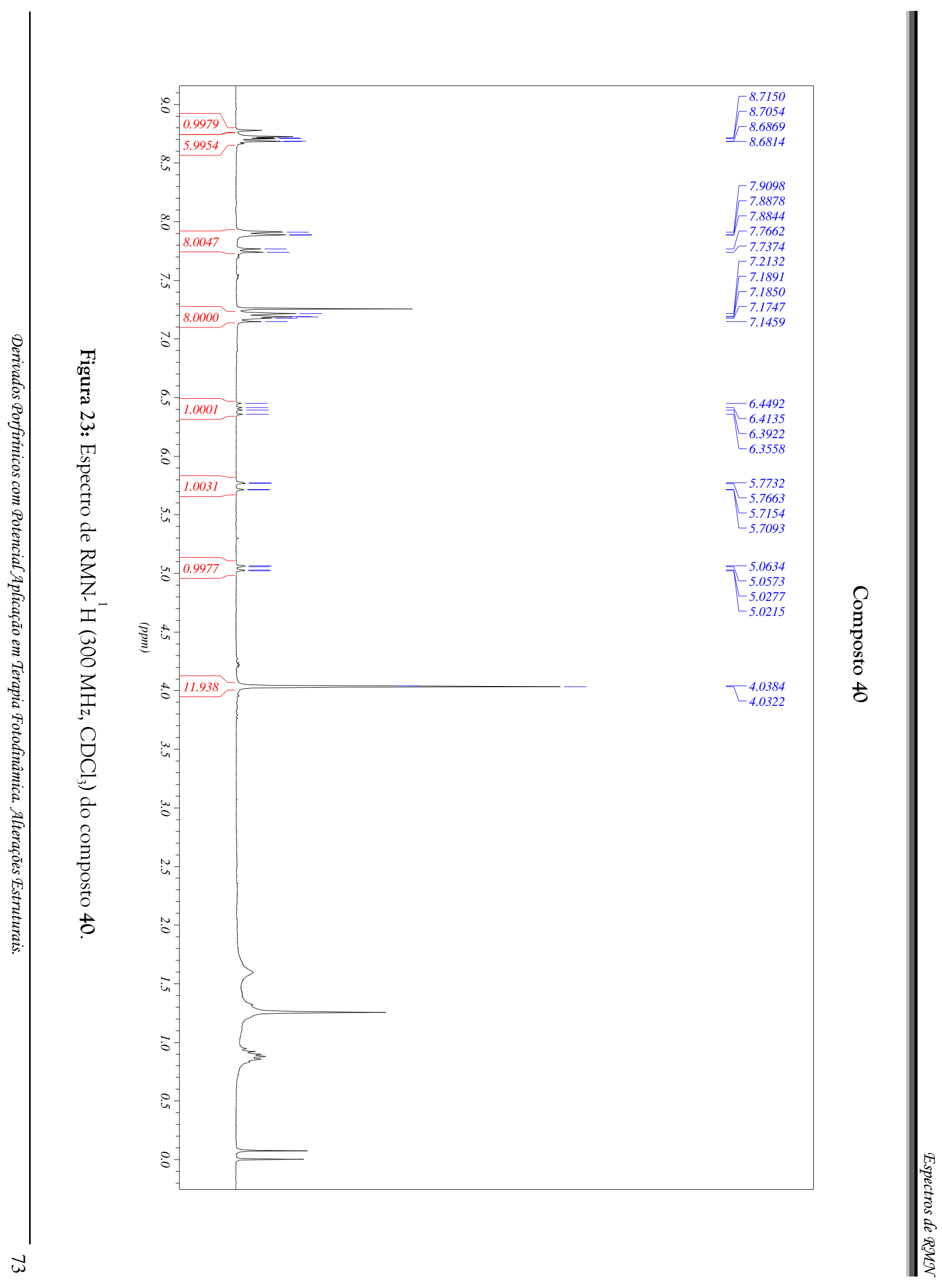




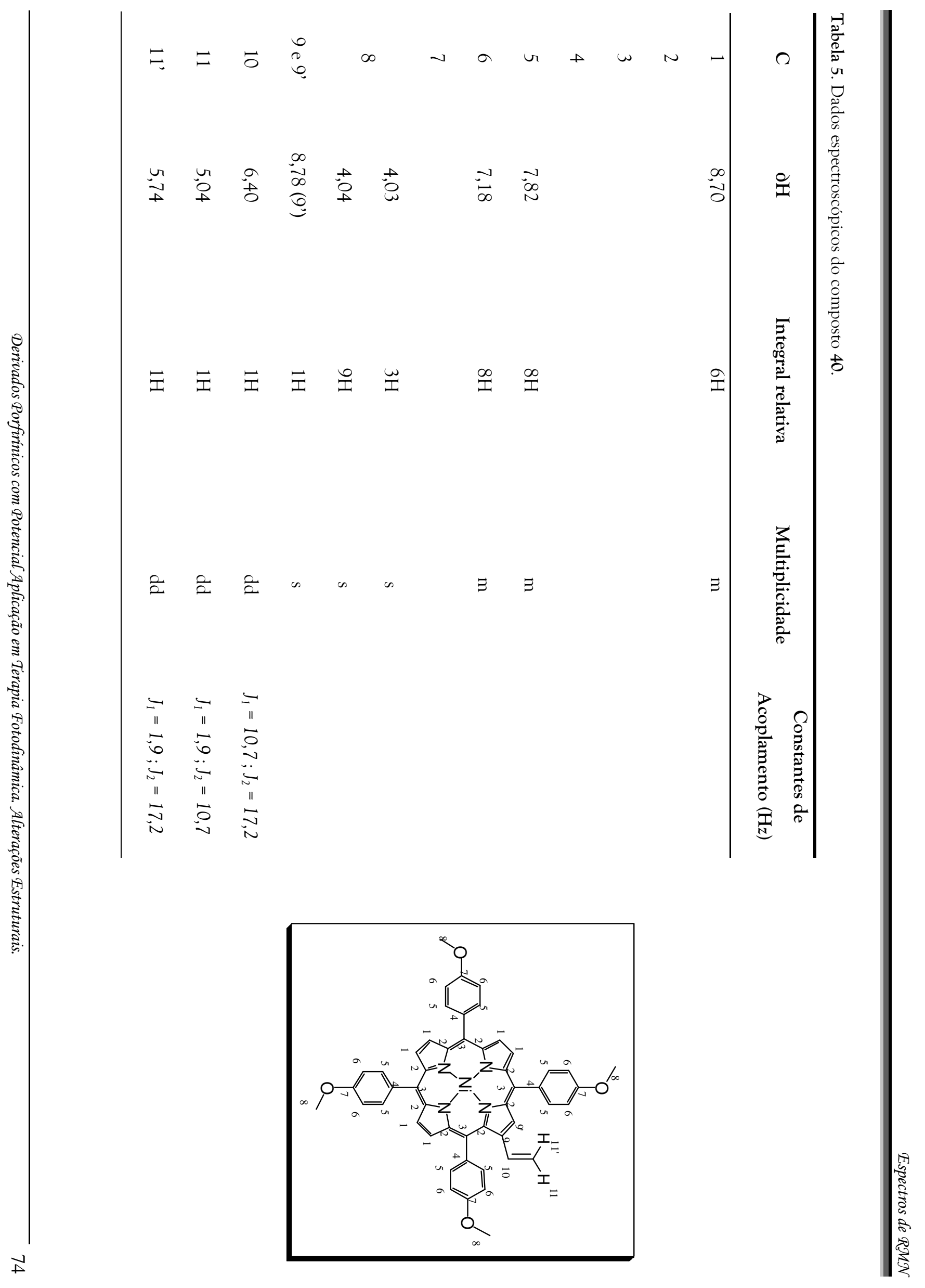




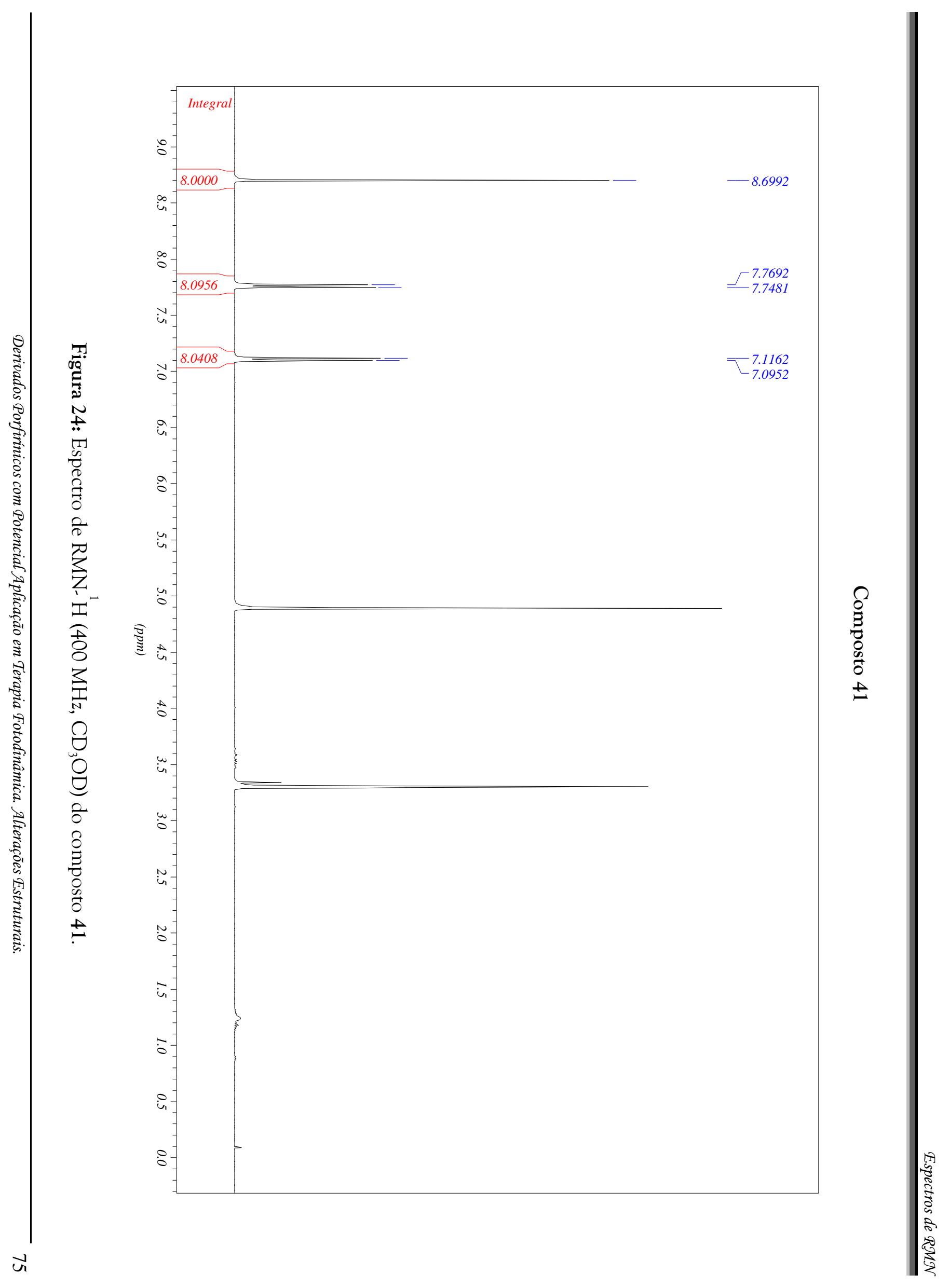




\section{Espectro de RMN ${ }^{13} \mathrm{C}\{\mathrm{H}\}$}

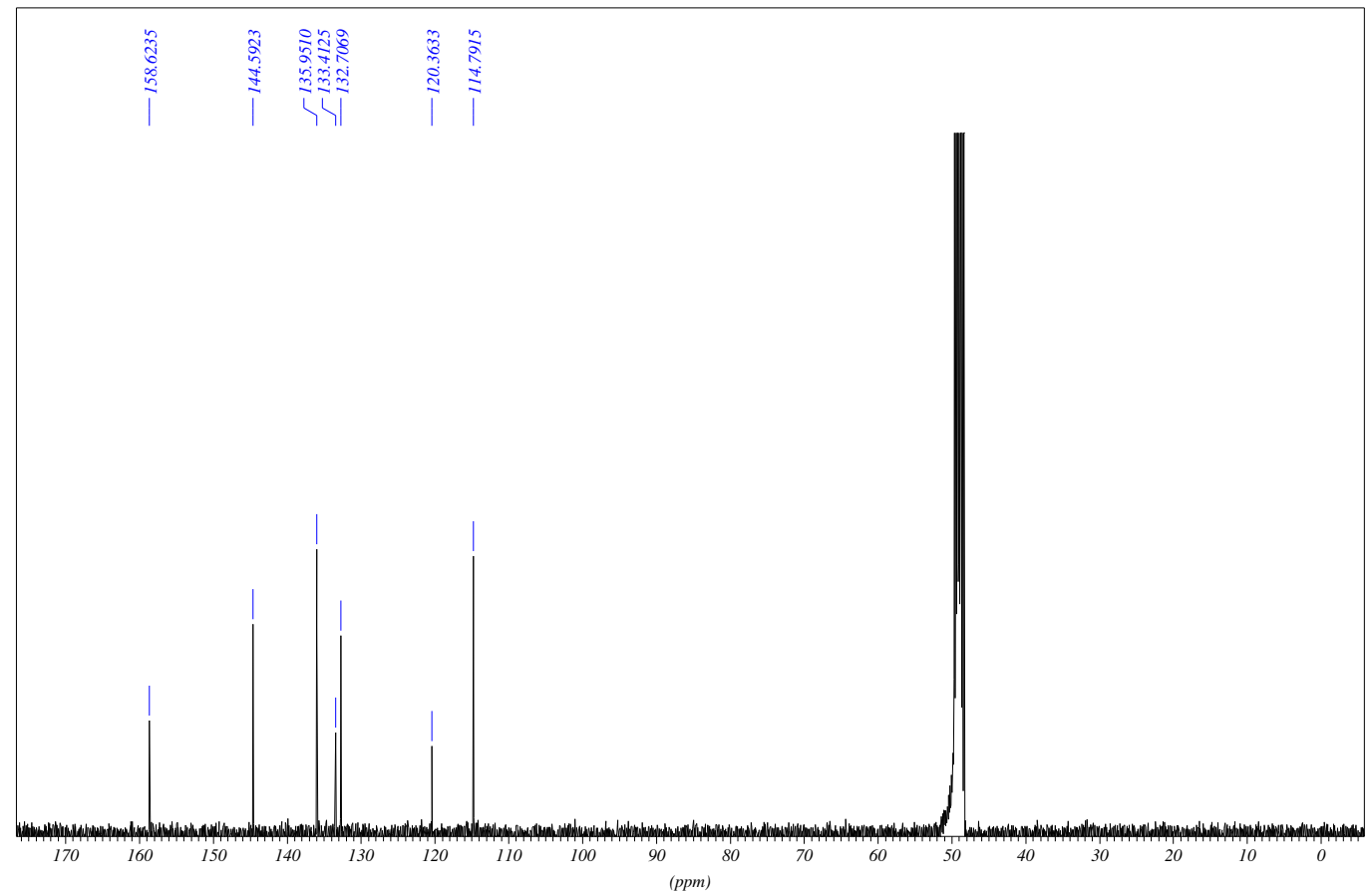

Espectro de RMN ${ }^{13} C(D E P T-135)$ *

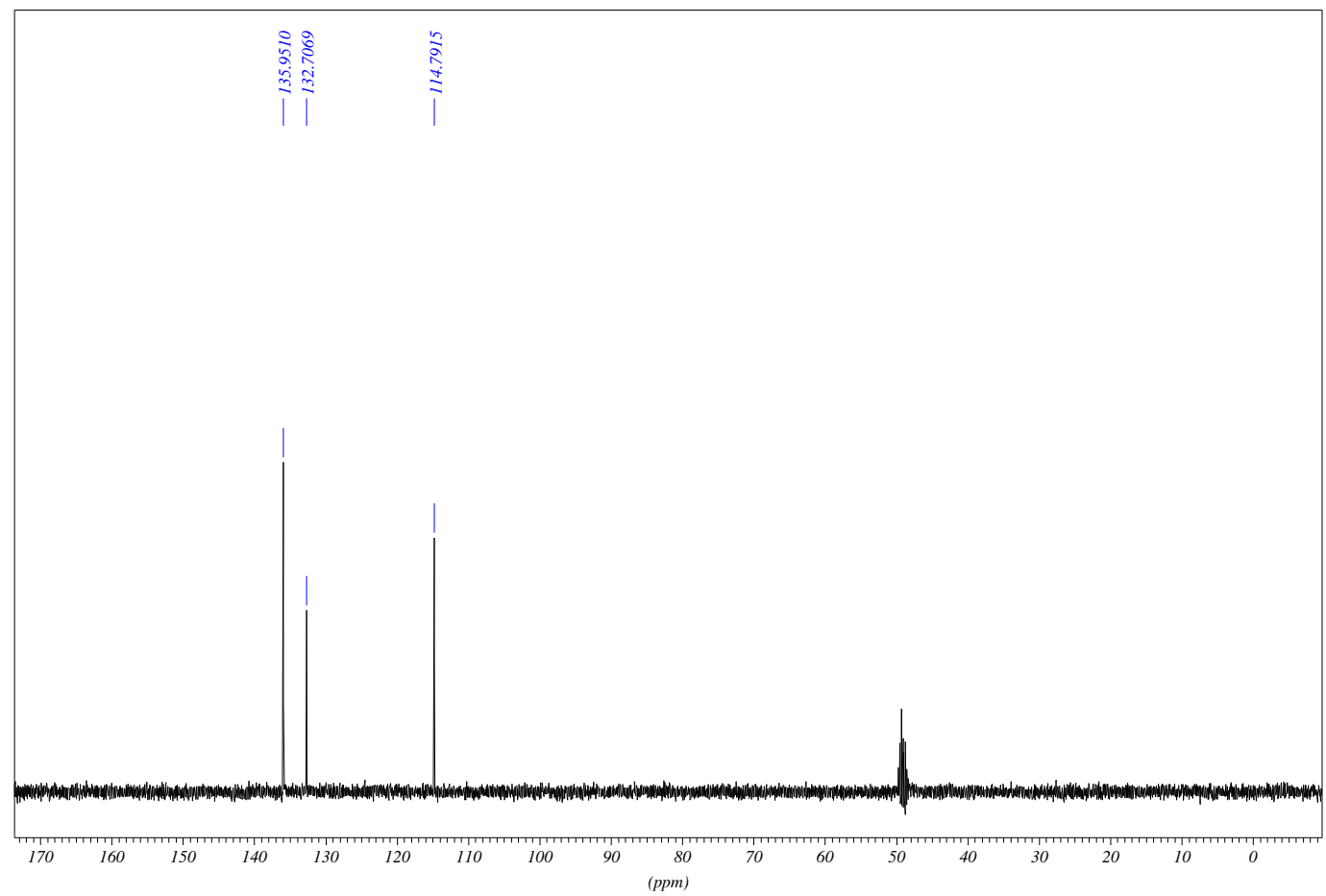

* Espectro de RMN ${ }^{13} \mathrm{C}\left(100 \mathrm{MHz}, \mathrm{CD}_{3} \mathrm{OD}\right)$ DEPT-135 do composto 41. $\uparrow\left(\mathrm{CH}, \mathrm{CH}_{3}\right), \downarrow\left(\mathrm{CH}_{2}\right)$

Figura 25: Espectros de $\mathrm{RMN}^{13} \mathrm{C}\left(100 \mathrm{MHz}, \mathrm{CD}_{3} \mathrm{OD}\right)$ do composto 41. 


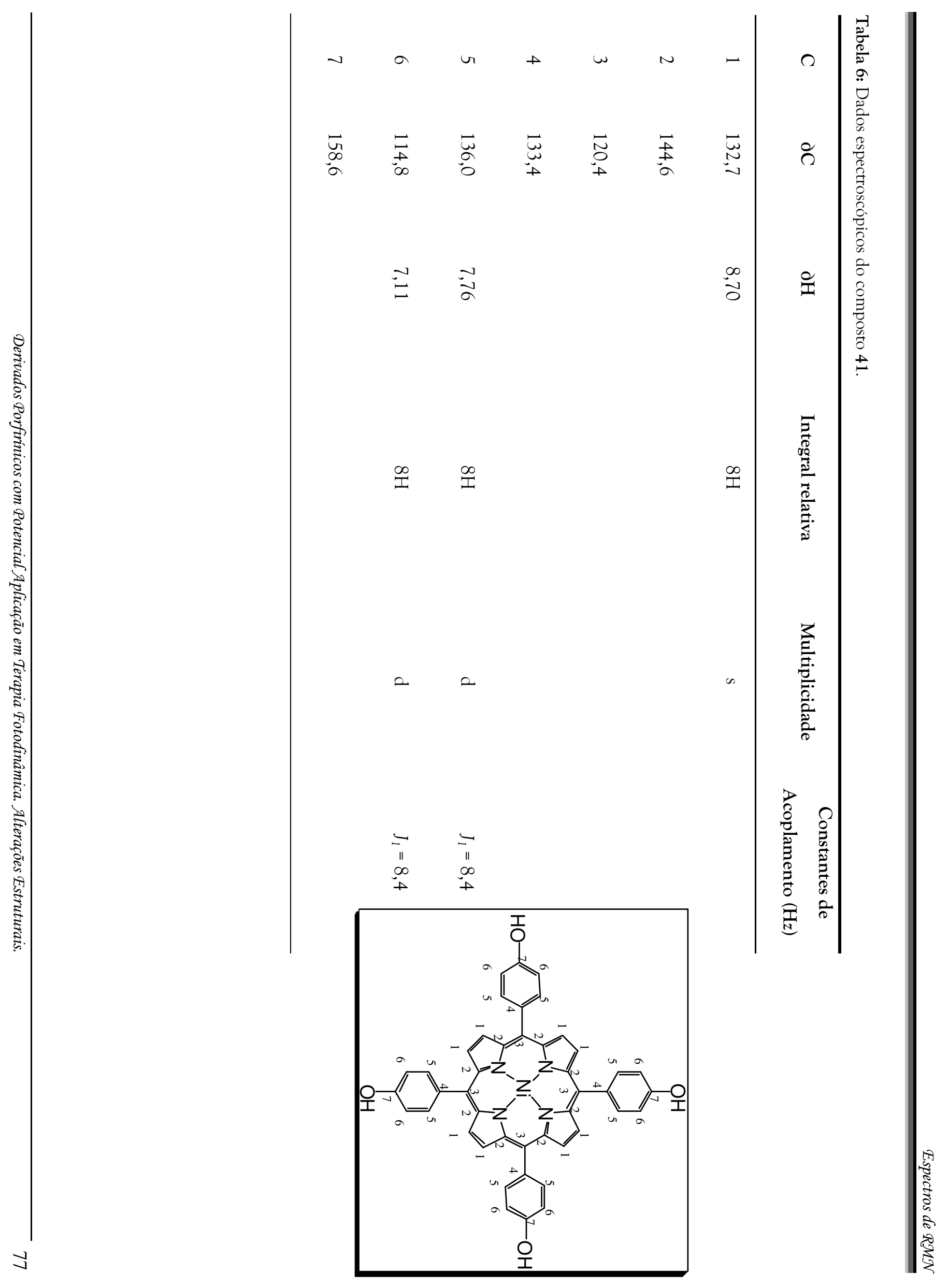




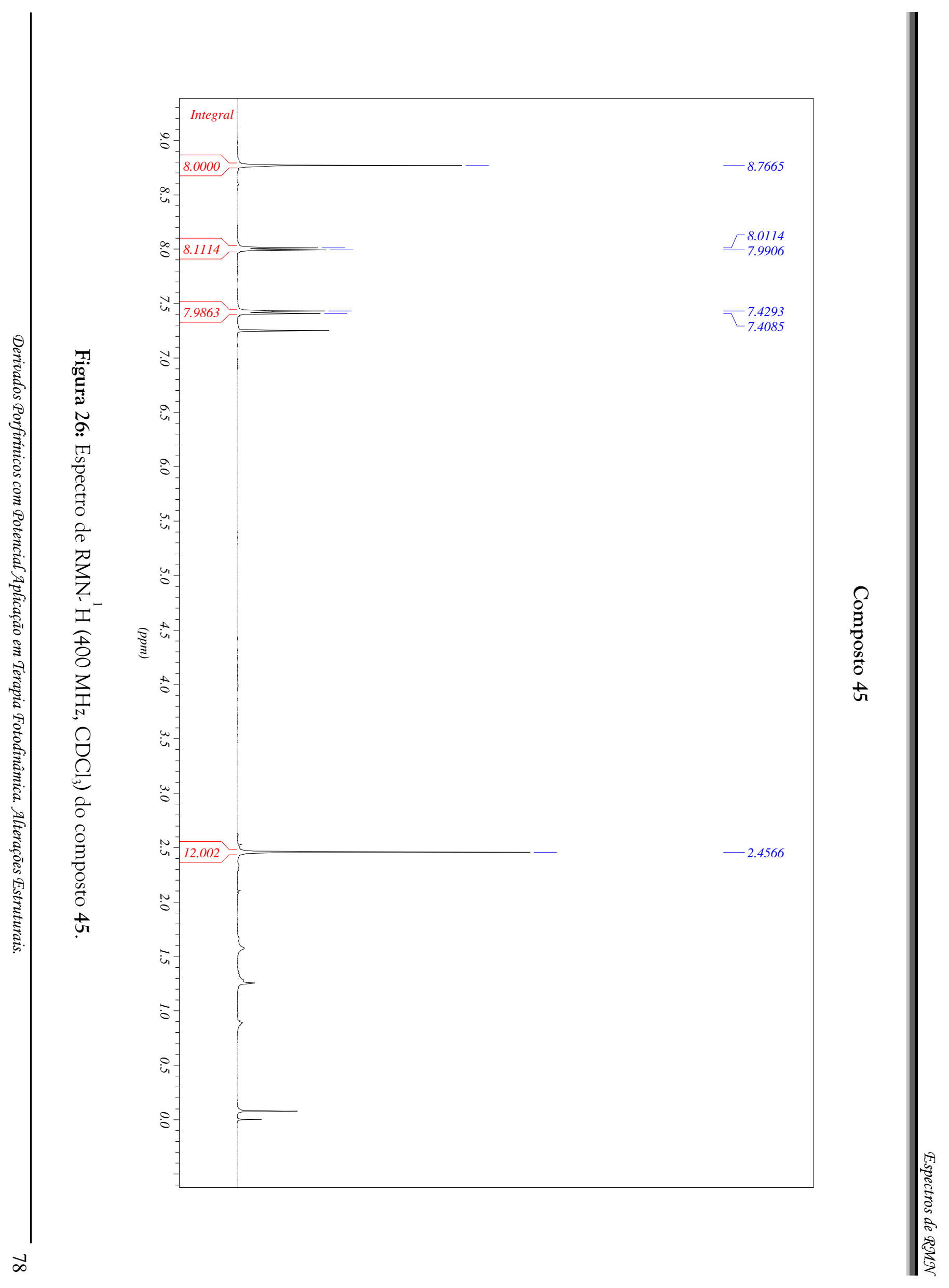


Espectro de RMN ${ }^{13} \mathrm{C}\{\mathrm{H}\}$

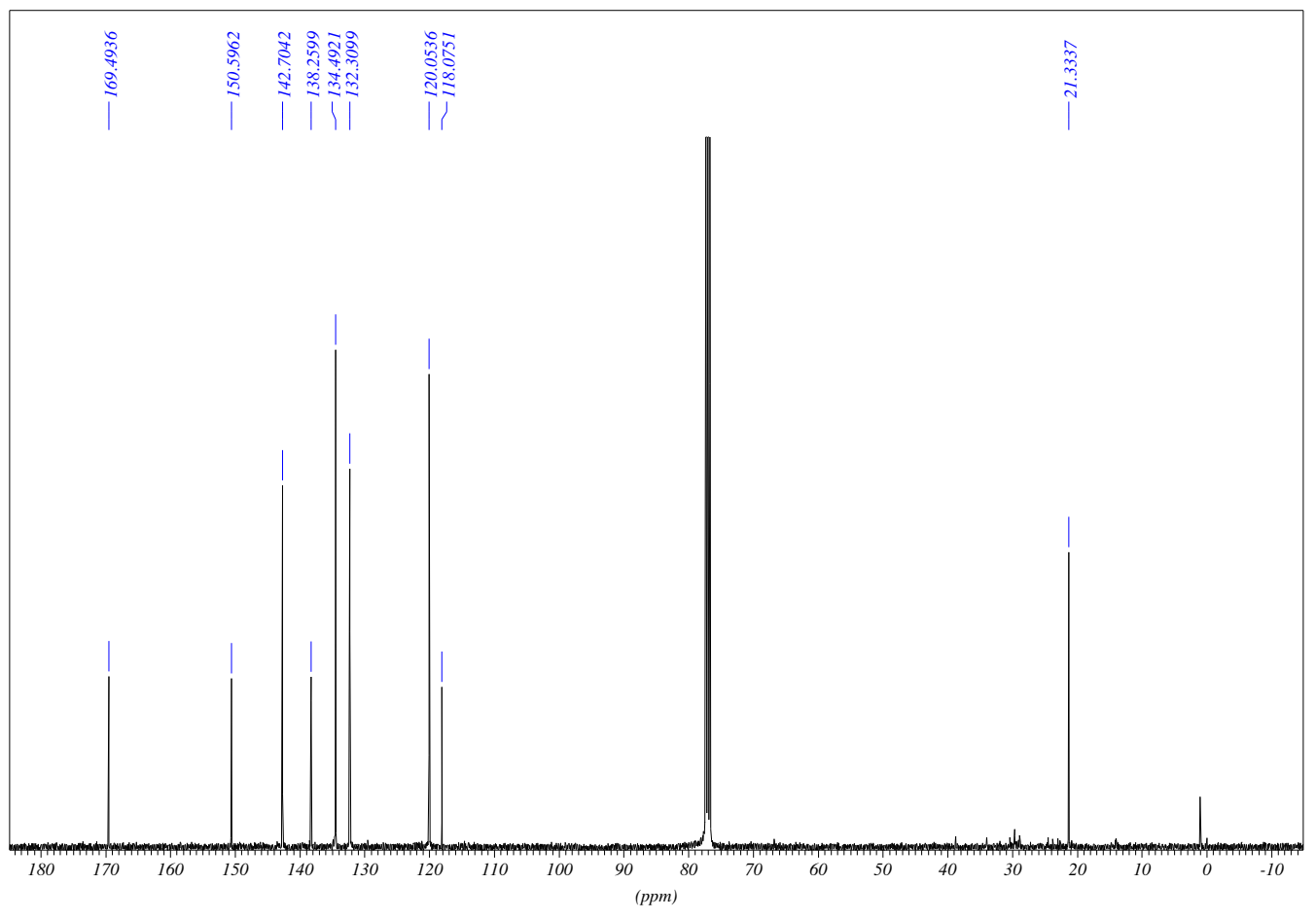

Espectro de RMN ${ }^{13} C(D E P T-135)$.*

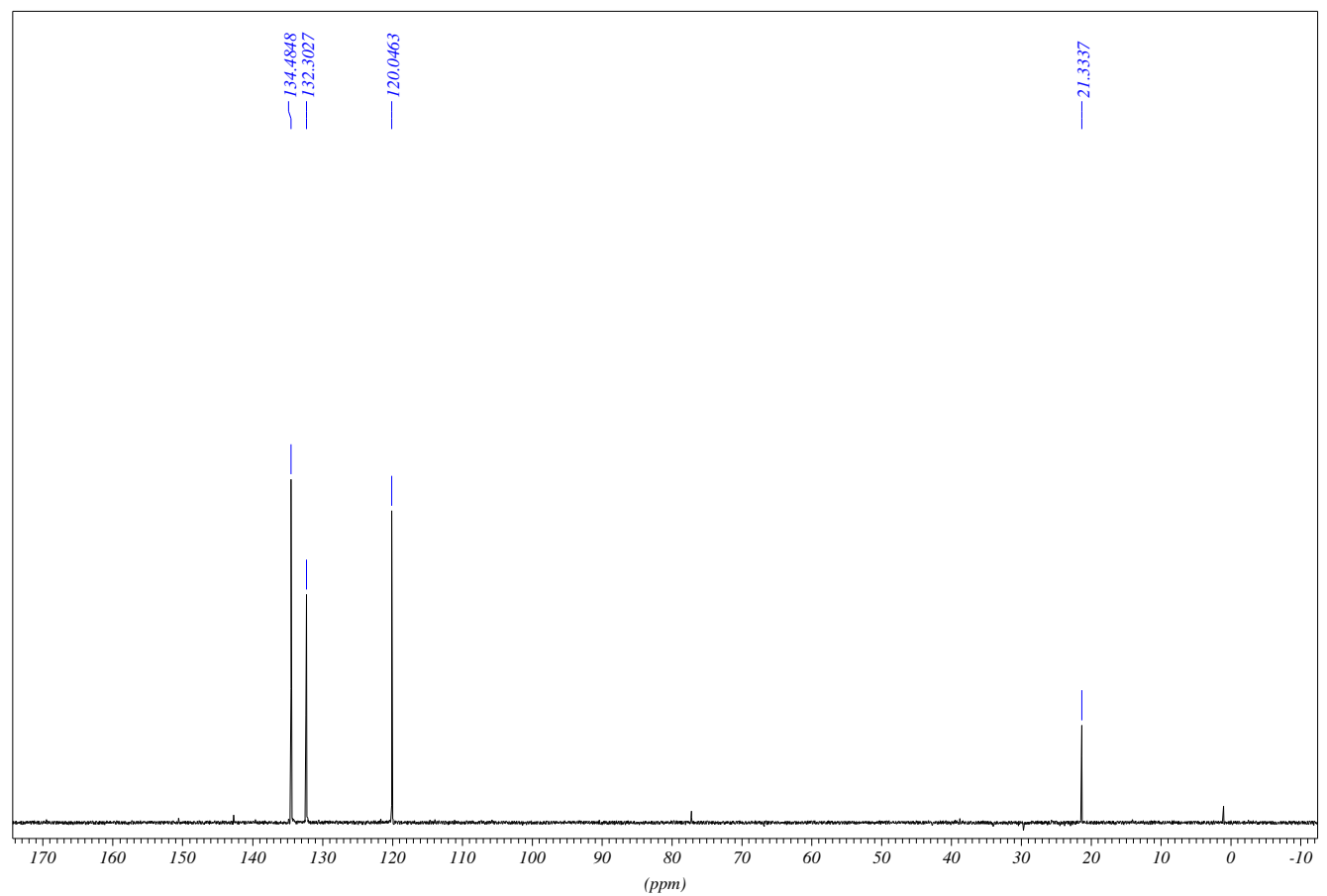

* Espectro de $\mathrm{RMN}^{13} \mathrm{C}\left(100 \mathrm{MHz}, \mathrm{CDCl}_{3}\right)$ DEPT-135 do composto 45. $\uparrow\left(\mathrm{CH}, \mathrm{CH}_{3}\right), \downarrow\left(\mathrm{CH}_{2}\right)$.

Figura 27: Espectros de $\mathrm{RMN}^{13} \mathrm{C}\left(100 \mathrm{MHz}, \mathrm{CDCl}_{3}\right)$ do composto 45. 


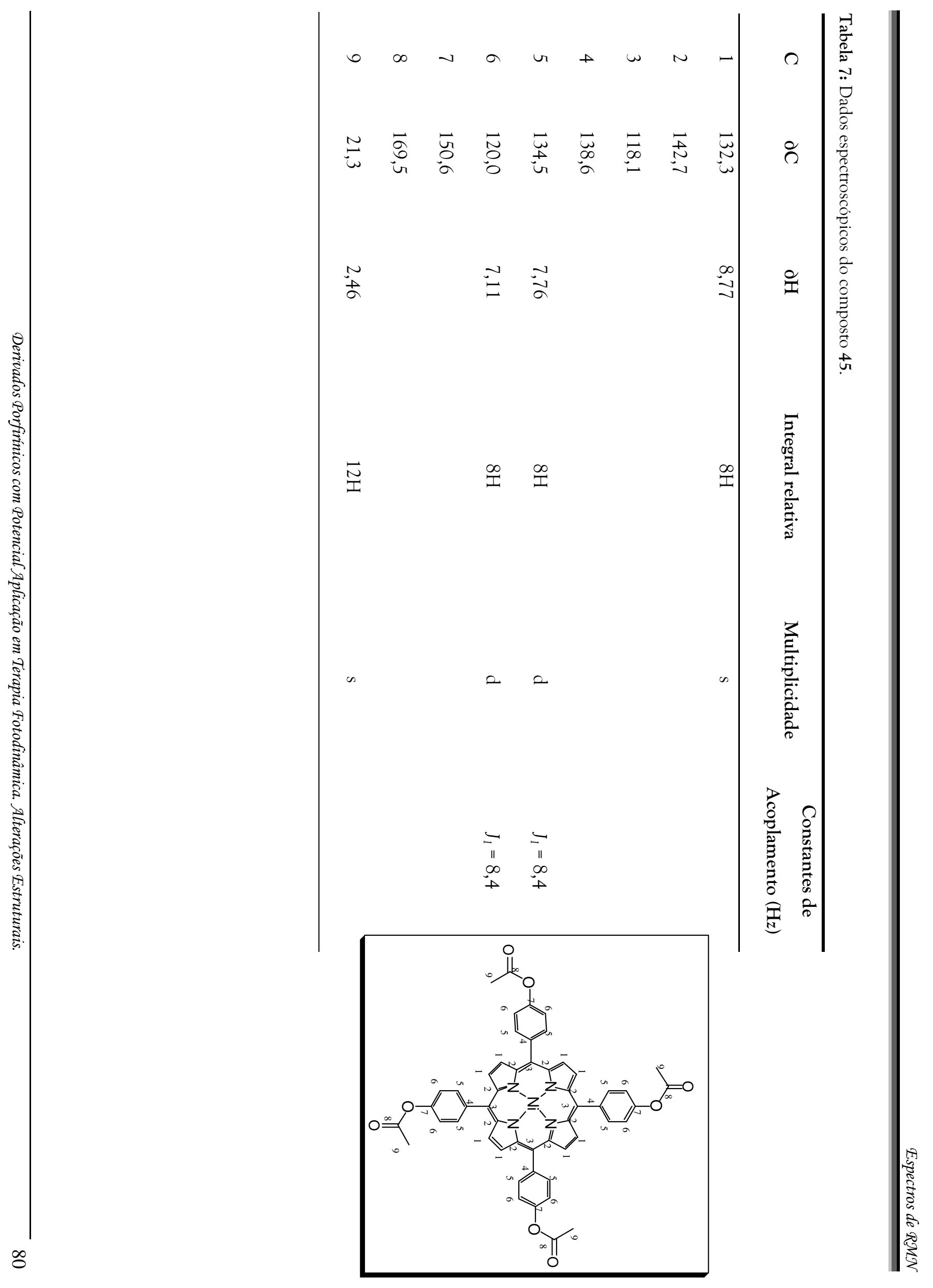




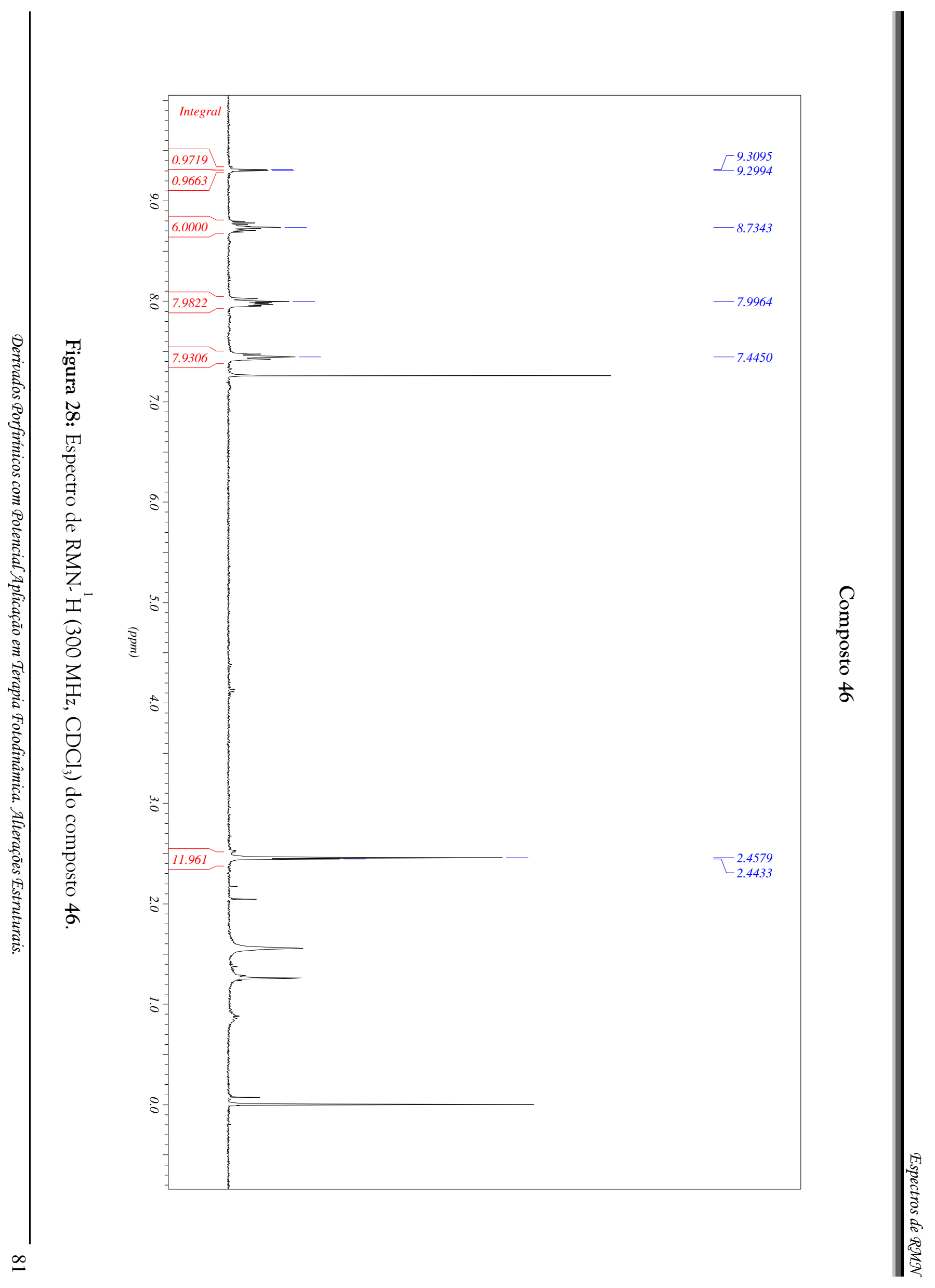




\section{Espectro de RMN ${ }^{13} \mathrm{C}\{\mathrm{H}\}$}

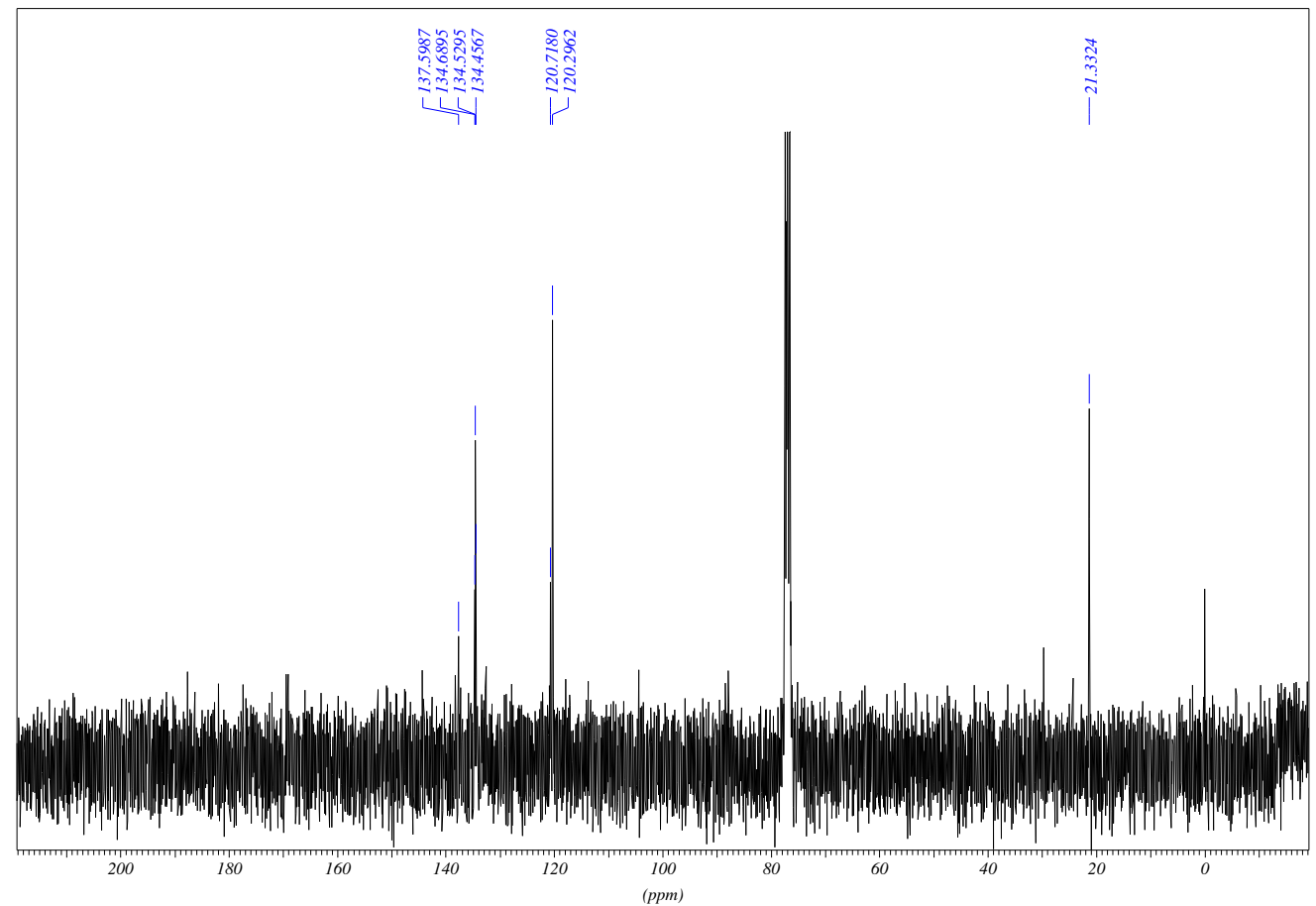

Espectro de RMN ${ }^{13} C(D E P T-135)$. *

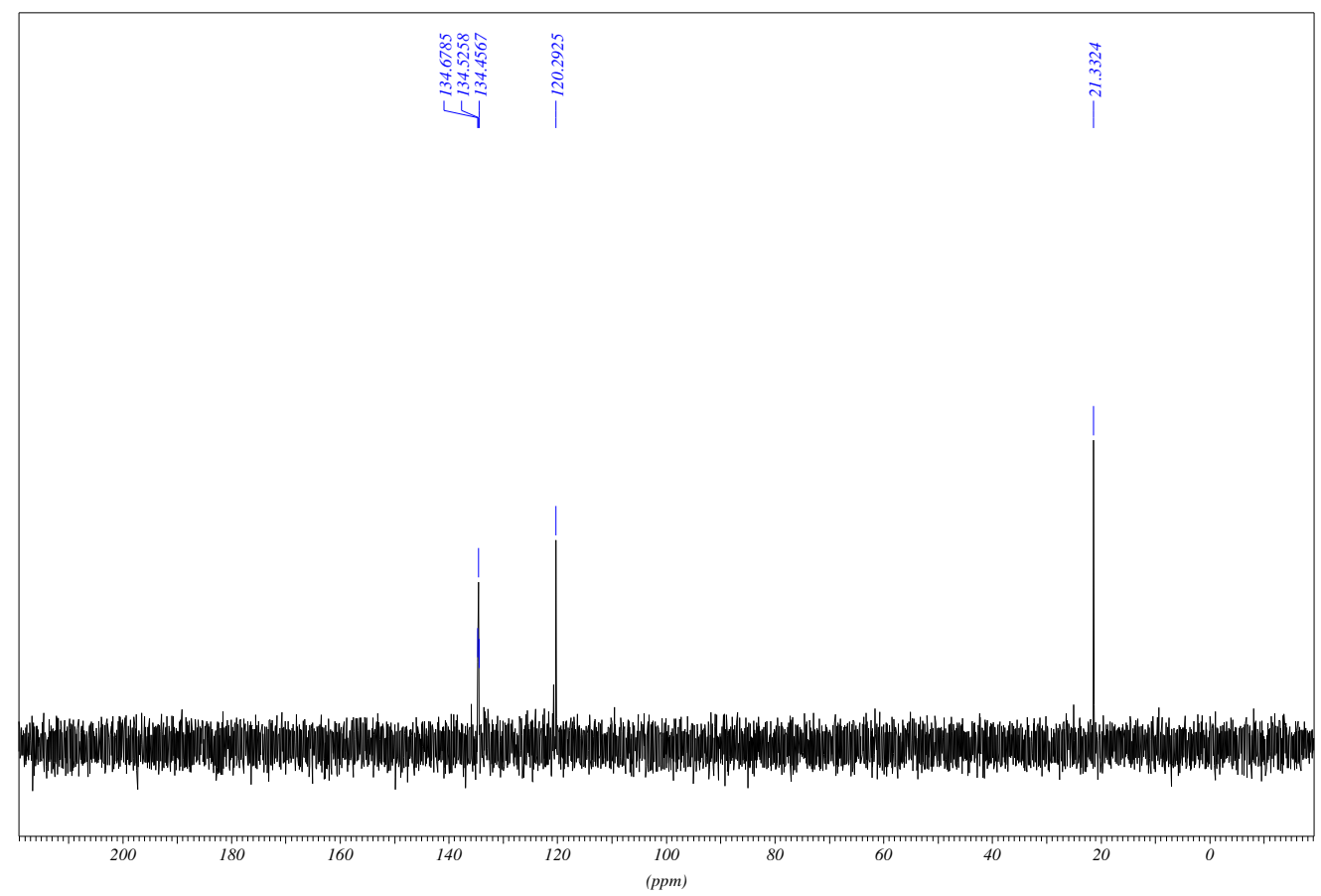

* Espectro de $\mathrm{RMN}^{13} \mathrm{C}\left(75,5 \mathrm{MHz}^{\mathrm{CDCl}} \mathrm{CDC}_{3}\right)$ DEPT-135 do composto $46 \uparrow\left(\mathrm{CH}, \mathrm{CH}_{3}\right), \downarrow\left(\mathrm{CH}_{2}\right)$.

Figura 29: Espectros de $\mathrm{RMN}^{13} \mathrm{C}\left(75,5 \mathrm{MHz}, \mathrm{CDCl}_{3}\right)$ do composto 46. 


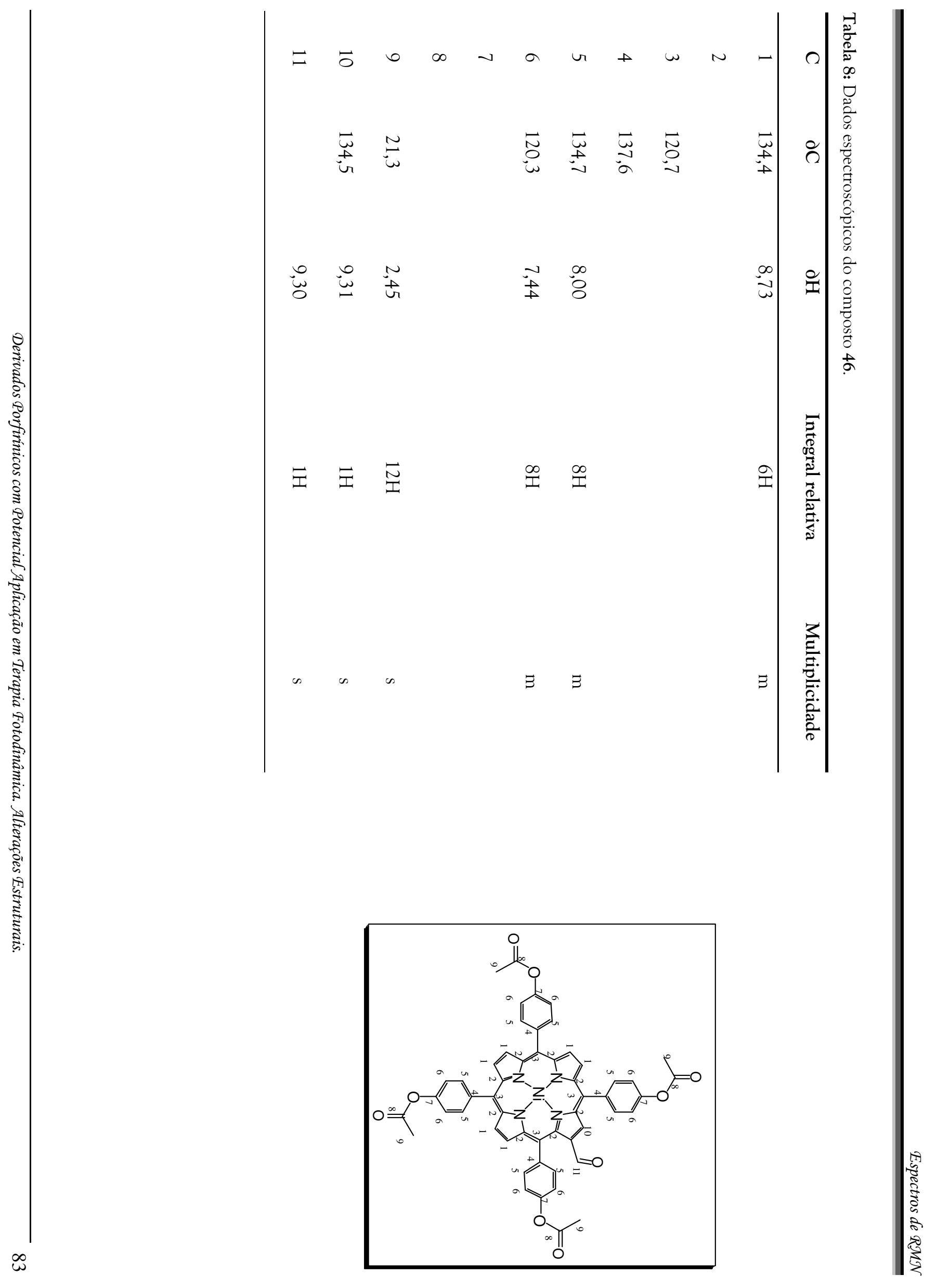




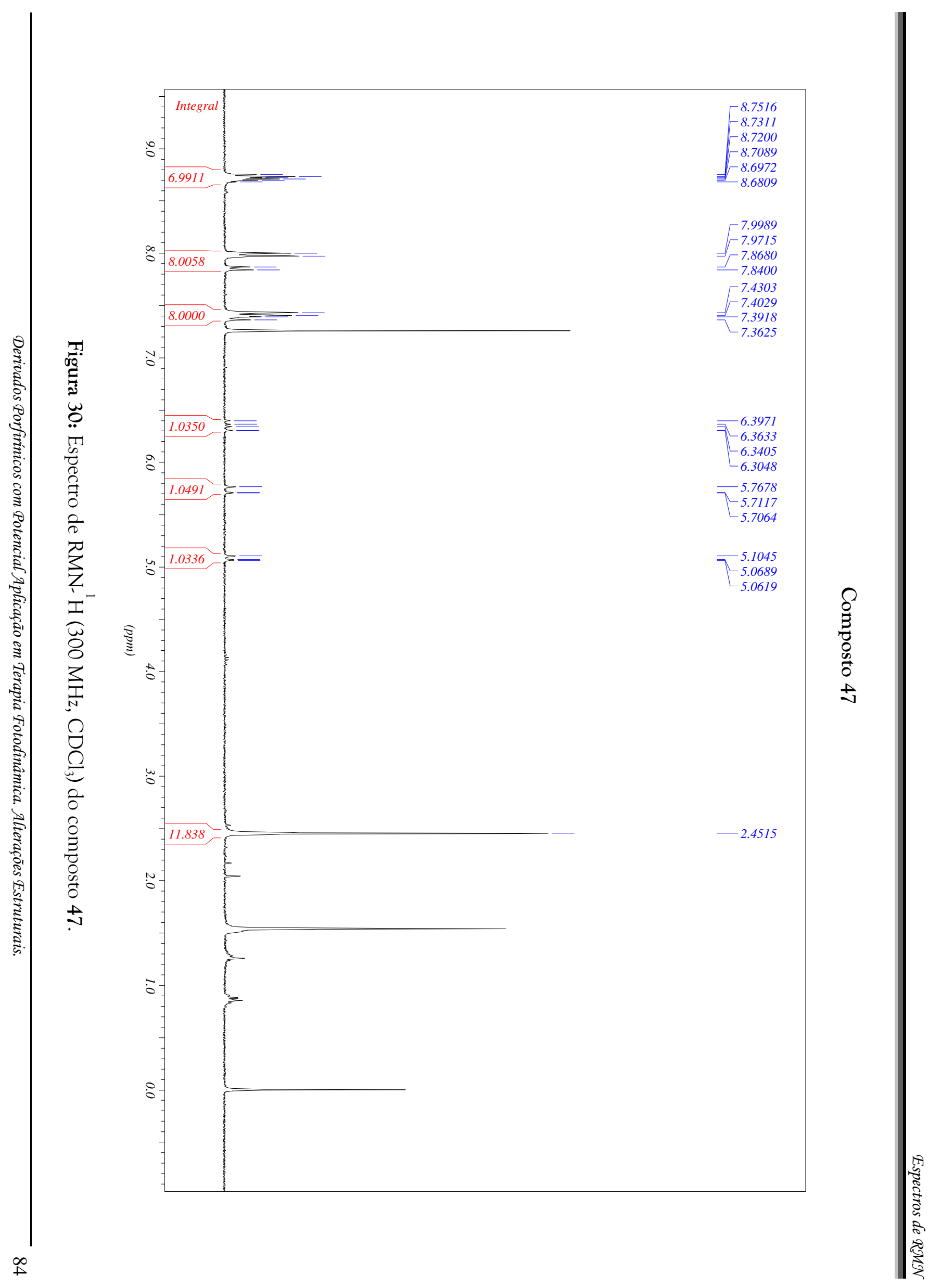


Espectro de RMN ${ }^{13} \mathrm{C}\{\mathrm{H}\}$

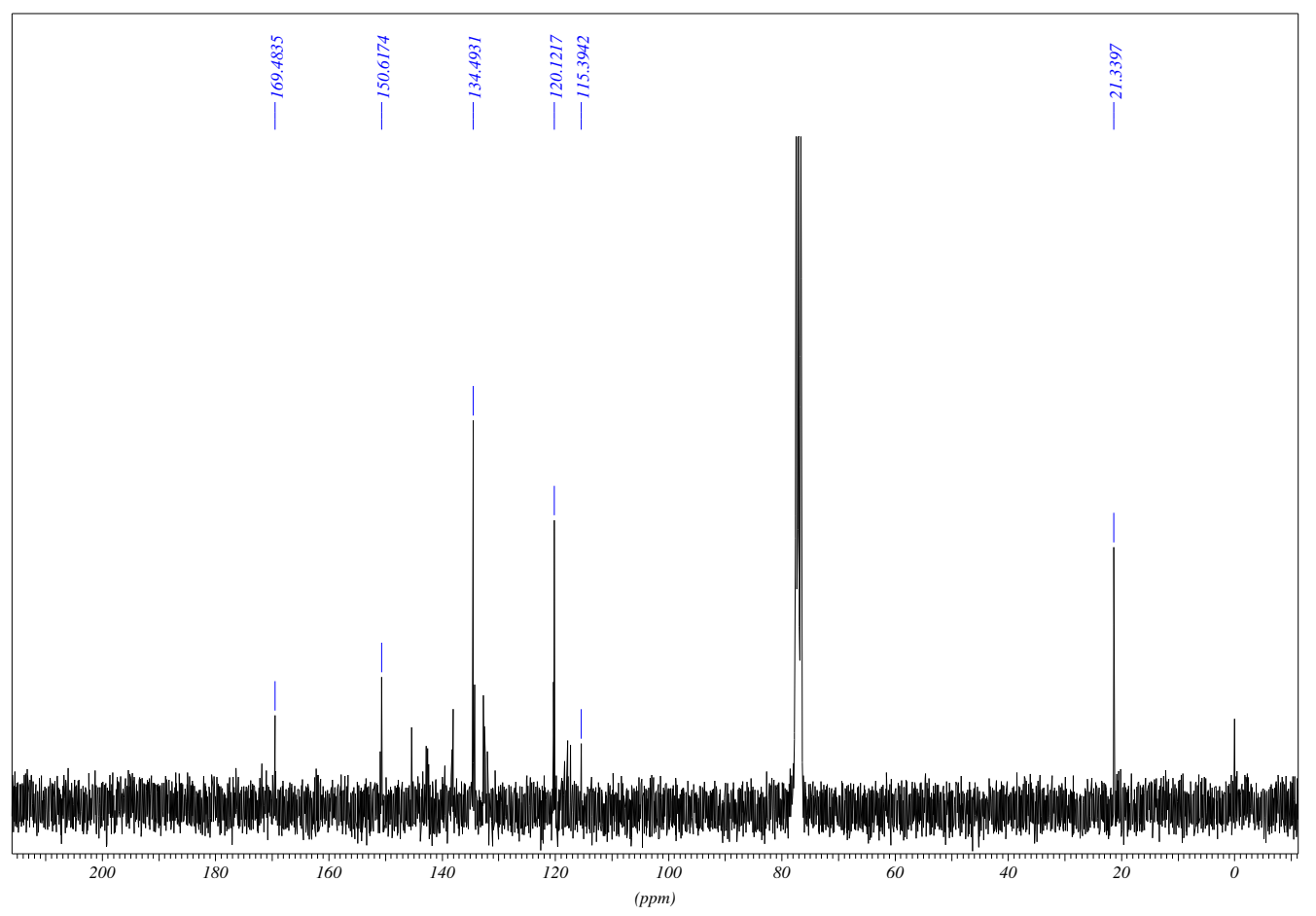

Espectro de RMN ${ }^{13} C(D E P T-135)$.*

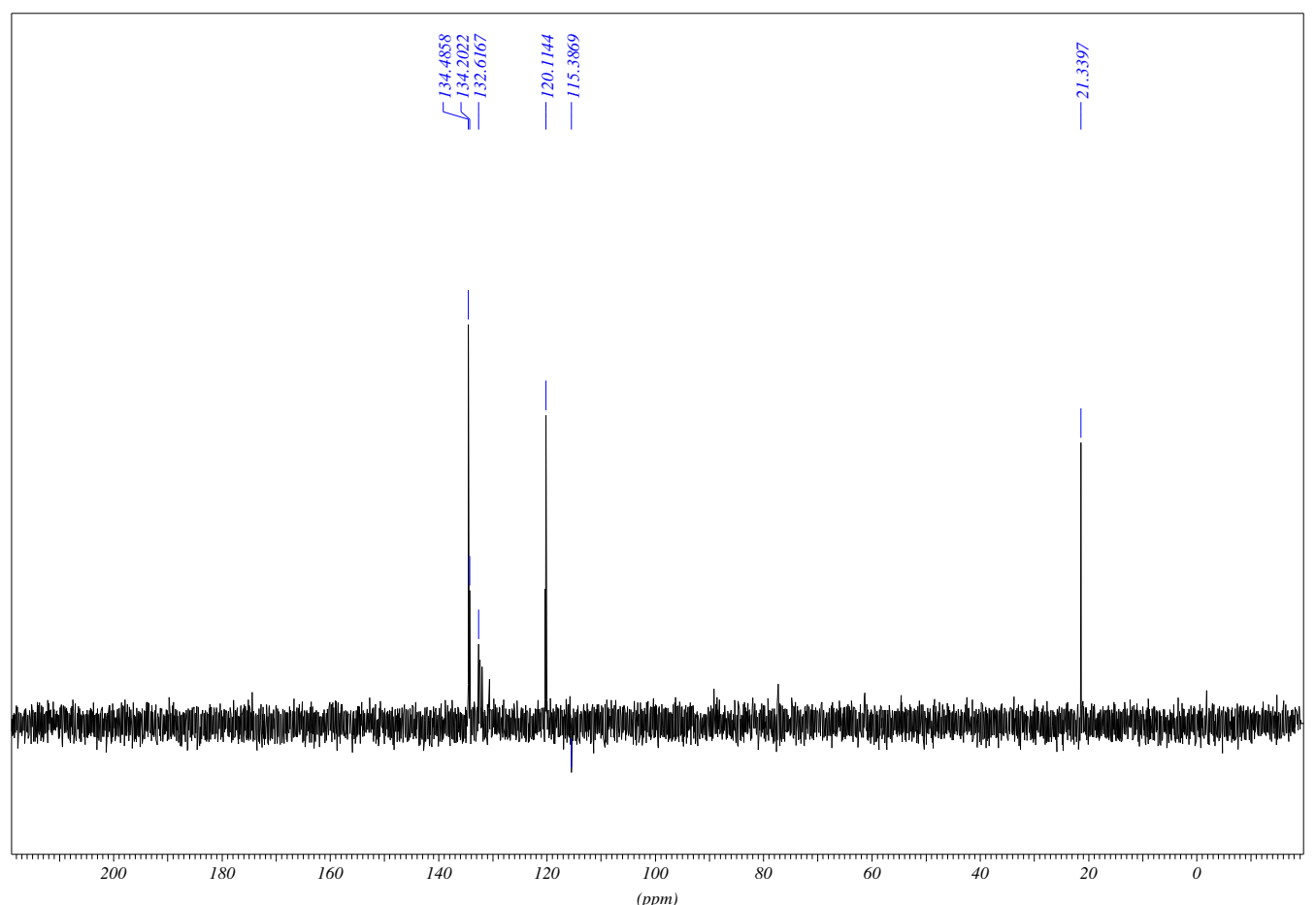

* Espectro de $\mathrm{RMN}^{13} \mathrm{C}\left(75,5 \mathrm{MHz}, \mathrm{CDCl}_{3}\right)$ DEPT-135 do composto 47. $\uparrow\left(\mathrm{CH}, \mathrm{CH}_{3}\right), \downarrow\left(\mathrm{CH}_{2}\right)$.

Figura 31: Espectros de $\mathrm{RMN}^{13} \mathrm{C}\left(75,5 \mathrm{MHz}^{13} \mathrm{CDCl}_{3}\right)$ do composto 47. 


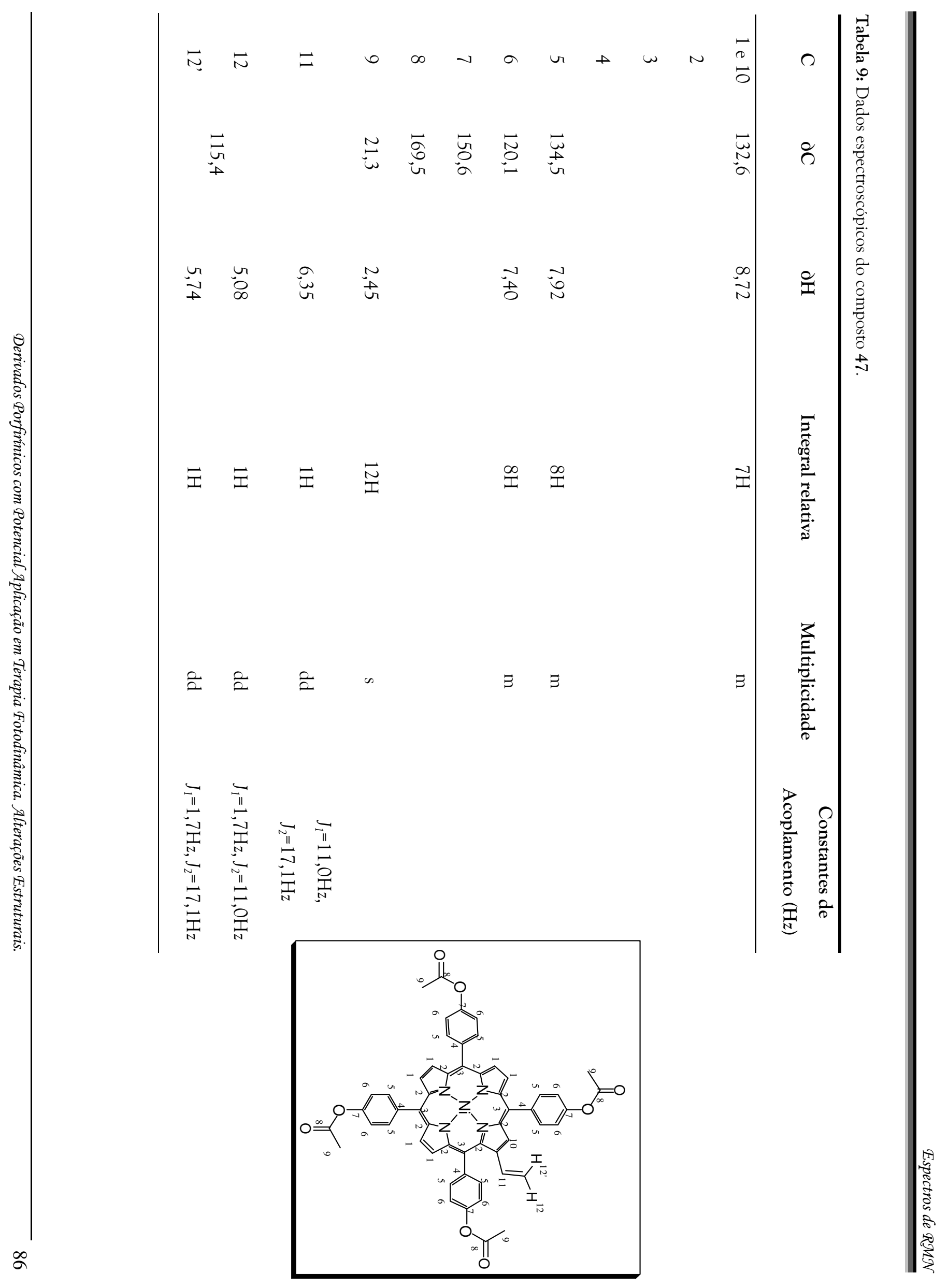




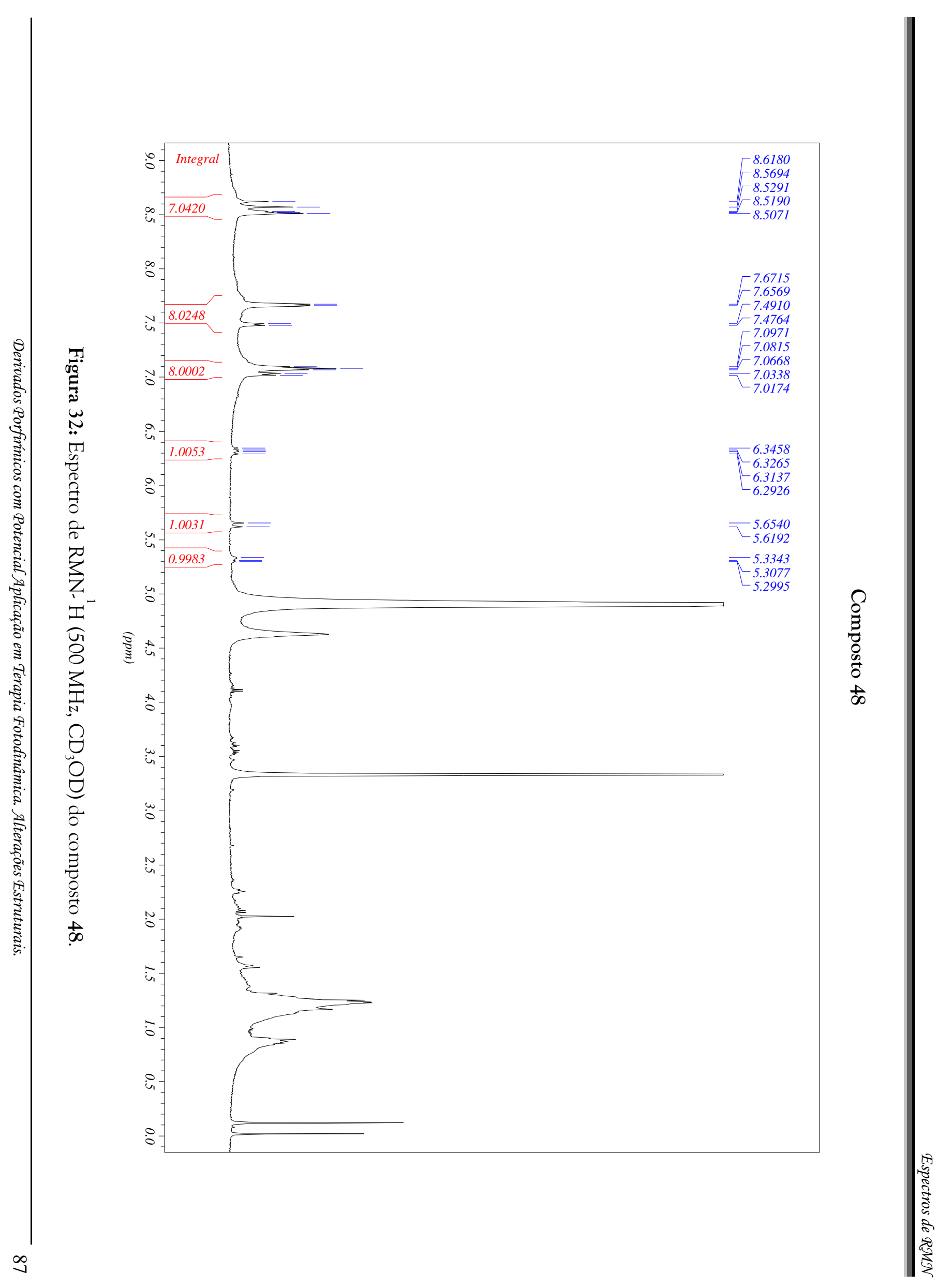




\section{Espectro de RMN ${ }^{13} \mathrm{C}\{\mathrm{H}\}$}

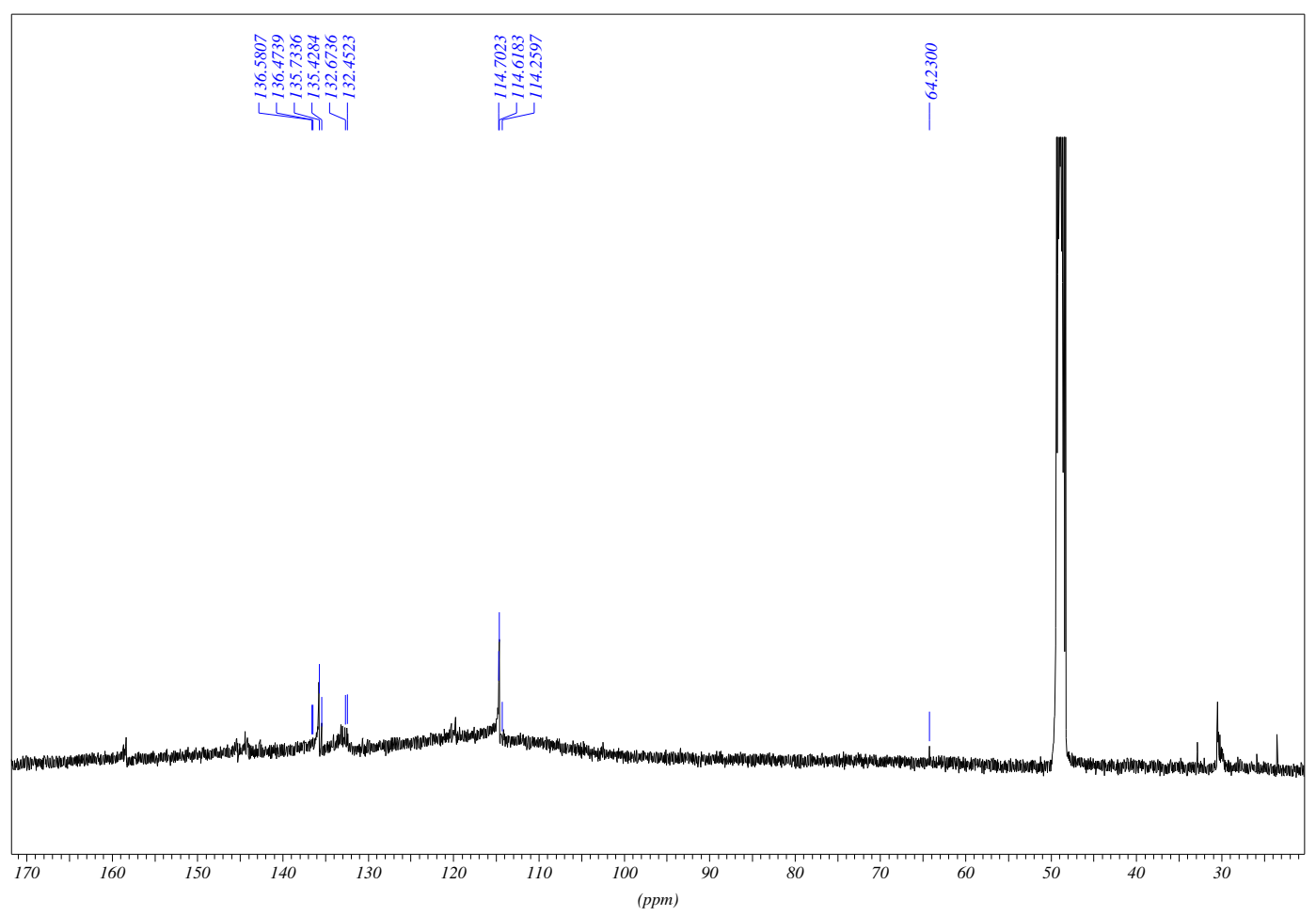

Espectro de RMN ${ }^{13} C$ (DEPT-135).*

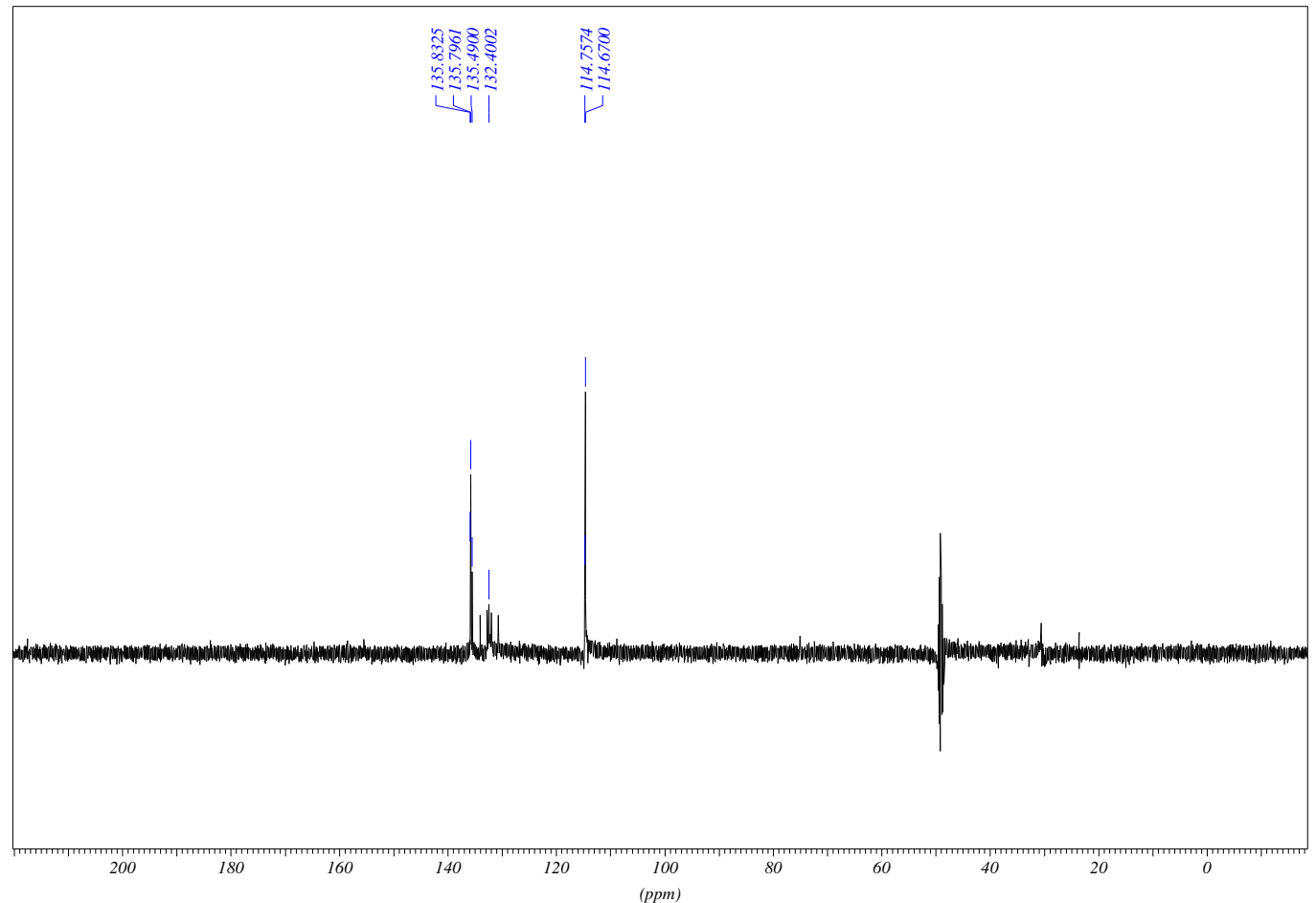

* Espectro de RMN ${ }^{13} \mathrm{C}\left(125 \mathrm{MHz}, \mathrm{CD}_{3} \mathrm{OD}\right)$ DEPT-135 do composto 48. $\uparrow\left(\mathrm{CH}, \mathrm{CH}_{3}\right), \downarrow\left(\mathrm{CH}_{2}\right)$.

Figura 33: Espectros de $\mathrm{RMN}^{13} \mathrm{C}\left(125 \mathrm{MHz}, \mathrm{CD}_{3} \mathrm{OD}\right)$ do composto 48. 


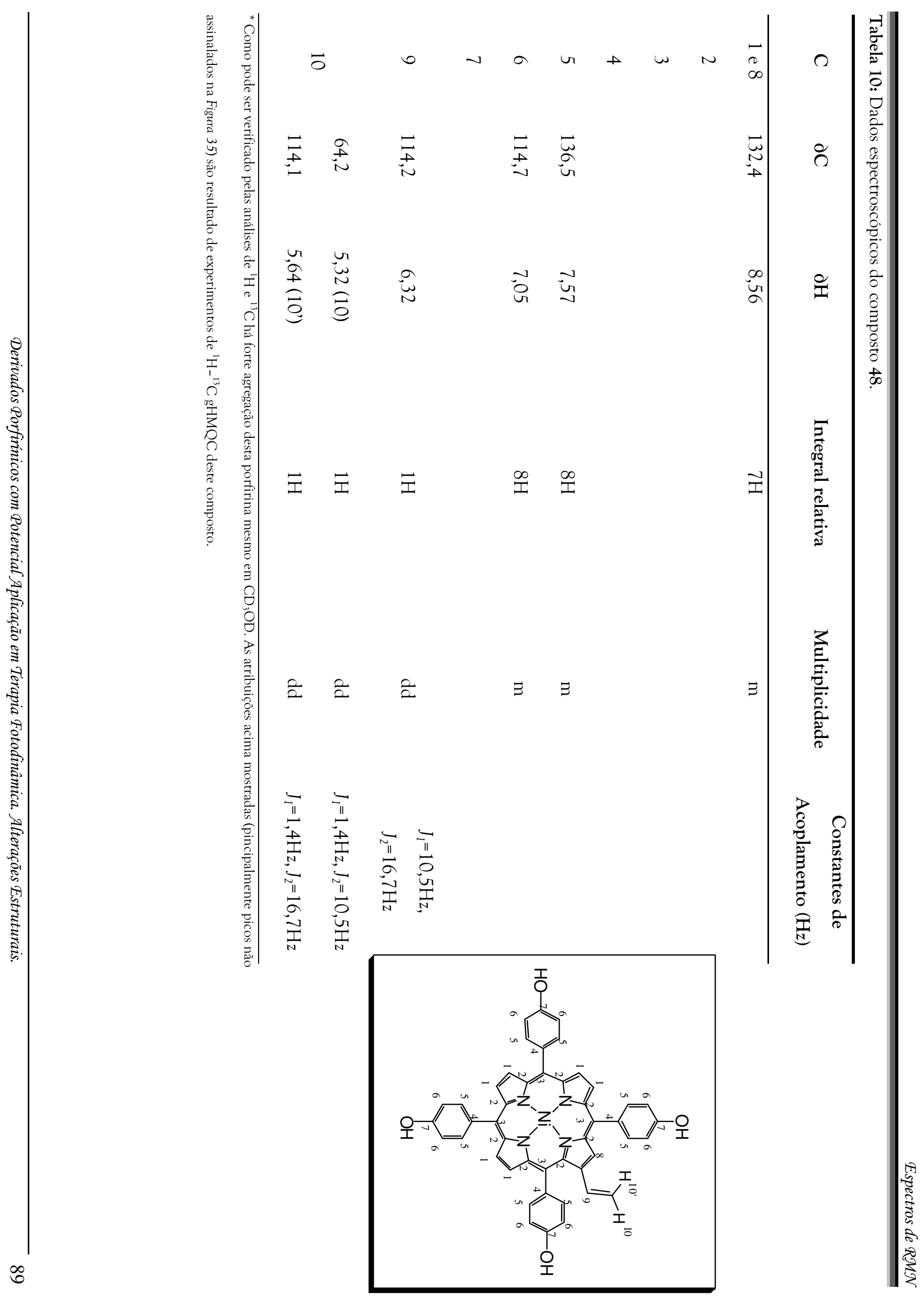




\section{Referências Bibliográficas}




\section{9 - Referências Bibliográficas}

1-J. March; “Advanced Organic Chemistry”; 4a edição, Wiley, New York, 1992.

2- H. Scheer, "Synthesis and Stereochemistry of Hidroporphyrins" em "The Porphyrins", editado por D. Dolphin, Vol 2, Academic Press, New York, 1978.

3- Bonnett, R. Chemical Aspects of Photodynamic Therapy, Vol.1, Gordon and Breach Science Publishers, 2000.

4- Simplício, F. I.; Maionchi, F.; Hioka, N.; Quim. Nova 2002, 25, 801.

5- Sternberg, E. D.; Dolphin, D. Tetrahedron 1998, 54, 4151.

6- a) Calzavara-Pinton, P. G.; Venturini, M. Sala, R. J. Eur. Acad. Dermatol. 2007, 21, 293. b) Calzavara-Pinton, P. G.; Venturini, M. Sala, R. J. Eur. Acad. Dermatol. 2007, 21, 439. c) Juzeniene, A.; Moan, J. Photodiag. Photodyn. Ther. 2007, 4, 3. d) Xu D.-Y. Photodiag. Photodyn. Ther. 2007, 4, 13. e) Juzeniene, A.; Moan, J.; Photodiag. Photodyn. Ther. 2007, 4, 80. f) Casas, A.; Batlle A. Photodiag. Photodyn. Ther. 2006, 3, 205. g) Lang, K., Mosinger, J., Wagnerová, D. M., Coord. Chem. Rev. 2004, 248, 321. h) Detty, M. R.; Gibson, S. L.; Wagner, S. J. J. Med. Chem. 2004, 47, 3897. i) Pushpan, S. K.; Venkatraman, S.; Anand, V. G.; Dankar, J.; Parmeswaran, D.; Ganesan, S.; Chadrashekar, T. K. Curr. Med. Chem. Anticancer Agents 2002, 2, 187. j) Madsen, S. J.; Sun, C. H.; Tromberg, B. W.; Wallace, V. P. Photochem. Photobiol. 2000, 72, 128. k) Ali, H.; van Lier, J. E. Chem. Rev. 1999, 99, 2379. 1) Dolphin, D. Can. J. Chem. 1994, 72, 1005.

7- a) Bruckner, C.; Dolphin, D. TetrahedronLett. 1995, 36, 3295. b) Adams, K. R.; Berenbaum, M. C.; Bonnett, R.; Nizhnik, A. N.; Salgado, A.; Valles, M. A. J. Chem. Soc., Perkin Trans. 1 1992, 1465. c) Kozyrev, A. N.; Pandey, R. K.; Medforth, C. J.; Zheng, G.; Doughety, T. J.; Smith, K. M. Tetrahedron Lett. 1996, 37, 747.

8- Nakajima, S.; Sakata, I.; Takemura, T. Chem. Abs. 1997, 126, 311893.

9. Whitlock Jr., H. W.; Hanauer, R.; Oester, M. Y.; Bower, B. K. J. Am. Chem. Soc. 1969, 91, 7485.

10- Bonnett, R.; White, R. D.; Winfield, UJ; Berenbaum, M. C. Biochem. J. 1989, 261, 277.

11- Otto Paul Hermann Diels (1876-1954) e Kurt Alder (1902-1958) foram agraciados com o

Prêmio Nobel de Química em 1950 "for their discovery and development of the diene 
synthesis". Primeira publicação no assunto: Diels, O. P. H.; Alder, K. Liebigs Ann. Chem. 1928, 460, 98 .

12- Fringuelli, F.; Taticchi, A. The Diels-Alder Reaction: Selected Practical Methods, John Wiley \& Sons, Inc., 2002. ISBN: 0-470-84581-3 (Electronic).

13- a) Silva, A. M. G.; Tomé, A. C.; Neves, M. G. P. M. S.; Silva, A. M. S.; Cavaleiro, J. A. S. J. Org. Chem. 2005, 70, 2306. b) Silva, A. M. G.; Tomé, A. C.; Neves, M. G. P. M. S.; Cavaleiro, J. A. S.; Kappe, O. Tetrahedron Lett. 2005, 46, 4723. c) Zhao, S.; Neves, M. G. P. M. S.; Tomé, A. C.; Silva, A. M. S.; Cavaleiro, J. A. S.; Domingues, M. R. M.; Correia, A. J. F. Tetrahedron Lett. 2005, 46, 2189. d) Faustino, M. A. F.; Neves, M. G. P. M. S.; Tomé, A. C.; Silva, A. M. S.; Cavaleiro, J. A. S. Arkivoc 2005, IX, 332. e) Alonso, C. M. A.; Neves, M. G. P. M. S.; Tomé, A. C.; Silva. A. M. S.; Cavaleiro, J. A. S. Eur. J. Org. Chem. 2004, 3233. f) Cavaleiro, J. A. S.; Neves, M. G. M. S.; Tomé, A. C. Arkivoc 2003, XIV, 107. g) Mettath, S.; Dougherty, T. J.; Pandey, R K. Tetrahedron Lett. 1999, 40, 6171. h) Faustino, M. A. F.; Neves, M. G. P. M. S.; Vicente, M. G. H.; Silva, A. M. S.; Cavaleiro, J. A. S. Tetrahedron Lett. 1996, 37, 3569. i) Morgan, A. R.; Kohli, D. H. Tetrahedron Lett. 1995, 36, 7603. j) Morgan, A. R.; Garbo, G. M.; Keck, R. W.; Miller, R. A.; Selman, S. H.; Skalkos, D. J. Med. Chem. 1990, 33, 1258. k) Pangka, V. S.; Morgan, A. R.; Dolphin, D. J. Org. Chem. 1986, 51, 1094. 1) Cavaleiro, J. A. S.; Jackson, A. H.; Neves, M. G. P. M. S.; Pao, K. R. N. J. Chem. Soc. Chem. Commun. 1985, 776. m) Morgan, A. R.; Pangka, V. S.; Dolphin, D. J. Chem. Soc. Chem. Commun. 1984, 1047.

14- Fernandes, A. C.; Herold, B.; Maia, H.; Rauter, A. P.; Rodrigues, J. A. Guia IUPAC para a Nomenclatura de Compostos Organicos, Ed. Liedel, Lisboa, 2002.

15- Carey, F.; Sudberg, R. J. Advanced Organic Chemistry, Part B, 4th ed., Kluwer Academic/Plenum Publishers, New York, 2001.

16- a) Sauer, J. Angew. Chem. Int.. Ed. 1966, 5, 211. b) Sauer, J. Angew. Chem. Int. Ed. 1967, 6, 16. c) Nicolaou, K. C.; Snyder, S. A.; Montagnon, T.; Vassilikogiannakis, G. Angew. Chem. Int. Ed. 2002, 41, 1668. d) Corey, E. J. Angew. Chem. Int. Ed. 2002, 41, 1650. e) Fringuelli, F.; Taticchi, A. The Diels-Alder Reaction: Selected Practical Methods, Jonh Wiley \& Sons, New York, 2002. f) Takao, K.; Munakata, R.; Tadano, K. Chem Rev. 2005, 105, 4779. g) Brocksom, T. J.; Nakamura, J.; Ferreira, M. L.; Brocksom, U. J. Braz. Chem. Soc. 2001, 12, 
597. h) W. Carruthers Cycloaddition Reactions in Organic Synthesis, vol.8, Pergamon Press, Oxford, 1990.

17- Berson, J. A. Tetrahedron 1992, 48, 3.

18- Stork, G.; Van Tamelen, E. E. Friedman, L. J.; Burgstahler, A. W. J. Am. Chem Soc. 1951, $73,4501$.

19- a) Alder, K.; Stein, G.; von Budedenbrock, F.; Eckardt, W.; Frercks, W.; Schneider, S. Justus Liebgs Ann. Chem. 1934, 514, 1. b) Alder, K.; Stein, G.; Liebmann, M.; Rolland, E. Justus Liebgs Ann. Chem. 1934, 514, 197. c) Alder, K.; Stein, G.; Rolland, E.; Schulze, G. Justus Liebgs Ann. Chem. 1934, 514, 211.

20- a) Maestrin, A. P. J.; Tedesco, A. C.; Neri, C. R.; Gandini, M. E. F.; Serra, O. A.; Iamamoto, Y. J. Braz. Chem. Soc. 2004, 15, 708. b) Maestrin, A. P. J.; Ribeiro, A. O.; Tedesco, A. C.; Neri, Vinhado, F. S.; C. R. ; Serra, O. A.; Martins, P. R.; Iamamoto, Y.; Silva, A. M. G.; Tomé, A. C.; Neves, M. G. P. M. S.; Cavaleiro, J. A. S. J. Braz. Chem. Soc. 2004, 15, 923. 21- a) Callot, H. J. Tetrahedron 1973, 29, 899. b) Arnold, D. P.; Gaete-Holmes, R.; Johnson, A. W.; Smith, A. R. P.; Willians, G. A. J. Chem. Soc., Perkin Trans I 1978, 1660.

22- Tomé, J. P. C.; Neves, M. G. P. M. S.; Tomé, A. C.; Cavaleiro, J. A. S.; Mendonça, A. F.; Pegado, I. N.; Duarte, R.; Valdeira, M. L. Bioorg. Med. Chem. 2005, 13, 3878.

23- Inhoffen, H. H.; Fuhrhop, J. H.; Voigt, H.; Brockmann, H. Liebigs Ann. 1966, 695, 133.

24- Bonfantini, E. E.; Burrell, A. K.; Campbell, W. M.; Crossley, M. J.; Gosper, J. J.; Harding, M. M.; Officer, D. L.; Reid, D. C. W. J. Porphyrins Phthalocyanines 2002, 6, 708.

25- Rothemund, P.; Menotti, A. R. J. Am. Chem. Soc., 1948, 70, 1808.

26- Inhoffen, H. H.; Fuhrhop, J. H.; Voigt, H.; Brockmann, H. Liebigs Ann., 1966, 695, 133.

27-Mironov, A. F.; Moskalchuk, T. V.; Shashkov, A. S. Russ. J. Bioorg. Chem., 2004, 30, 261.

28- Johnson, A. W.; Oldfield, D. J. Chem. Soc. (C), 1966, 794.

29- Greene, T. W.; Wuts, P. Protective Groups in Organic Synthesis 1991, 2a ed.; Cap. 2, John $\& W i l e y$ Sons, New York.

30- Andrade, M. M.; Barros, M. T. Tetrahedron 2004, 60, 9235.

31- Koeller, S.; Lellouche, J-P. Tetrahedron Lett. 1999, 40, 7043.

32- a) Florent, J. C.; Ughetto-Monfrin, J.; Monneret, C. J. Org. Chem. 1987, 52, 1051. b) Oliveira, K. T.; Estudos Sintéticos e Teóricos Sobre Anulenos e Baquenolidas Tese de Doutoramento, Departamento de Química da FFCLRP/USP 2006. 
33- a) de Oliveira, K. T.; Neri, C. R.; Garcia, V. S.; Iamamoto, Y.; Serra, O. A.; Neves, M. G. P. M. S.; Tomé, A. C.; Silva, A. M. S.; Cavaleiro, J. A. S. "Síntese e Atividade Fotodinâmica de Novas Clorinas" In: II Workshop "Terapia Fotodinâmica: Integração dos Aspectos Moleculares, Tecnológicos e Aplicações na Área de Saúde", São Pedro - SP. Livro de Resumos, 2007. p. 84-85. b) de Oliveira, K. T.; Neves, M. G. P. M. S.; Tomé, A. C.; Silva, A. M. S.; Iamamoto, Y.; Serra, O. A.; Neri, C. R.; Garcia, V. S.; Cavaleiro, J. A. S. "A Synthetic Approach for the Synthesis of Substituted Chlorin Derivatives from Protoporphyrin-IX Dimethyl Ester". In: XII Blue Danube Symposium on Heterocyclic Chemistry, 2007, Tihany - Hungary. Book of Abstracts, 2007. p. 59. c) de Oliveira, K. T.; Silva, A. M. S.; Tomé, A. C.; Neves, M. G. P. M. S.; Neri, C. R.; Garcia, V. S.; Serra, O. A.; Iamamoto, Y.; Cavaleiro, J. A. S. Tetrahedron (artigo em fase de conclusão)

34- a) Yon-Hin, P.; Wijesekera, T. P.; Dolphin, D. Tetrahedron Lett., 1989, 30, 6135. b) Morgan, A. R.; Garbo, G. M.; Keck, R. W.; Miller, R. A.; Selman, S. H.; Skalkos, D. J. Med. Chem., 1990, 33, 1258. c) Pandey, R. K.; Jagerovic, N.; Ryan, J. M.; Dougherty, T. J.; Smith, K. M. Bioorg. Med. Chem. Lett, 1993, 3, 2615. d) Meunier, I.; Pandey, R. K.; Senge, M. O.; Dougherty, T. J.; Smith, K. M. J. Chem. Soc. Perkin Trans. 1, 1994, 961. e) Silva, A. M. G.; de Oliveira, K. T.; Faustino, M. A. F.; Neves, M. G. P. M. S.; Tomé, A. C.; Silva, A. M. S.; Cavaleiro, J. A. S.; Brandão, P.; Felix, V. Eur. J. Org. Chem. DOI: 10.1002/ejoc.200700852.

35- Fischer, F.; Graschew, G.; Sinn, H.J.; Maier-Borst, W.; Lorenz, W. J.; Schlag, P.M. Clin. Chim. Acta, 1998, 274, 89.

36- Rothmund, P. J. Am. Chem. Soc. 1936, 58, 625.

37- Adler, A. D.; Longo,F. R.; Finarelli, J. D.; Goldmacher, J.; Assour, J.; Korsakoff, L. J. Org. Chem. 1967, 32, 476.

38- Lindsey, J. S.; Schreiman, I. C.; Hsu, H. C.; Kearney, P. C.; Marguerettaz, A. M. J. Org. Chem. 1987, 52, 827.

39- Bonar-Law, R. P. J .Org .Chem. 1996, 61, 3623.

40- Perrin, D. D.; Armarego, W. L. F.; Perrin, D. R. Purification of Laboratory Chemicals, 2a edição, Pergamon Press Ltd, Oxford, 1980.

41- 1D WINNMR - NMR Postprocessing Program, versão 96.9.1.0, Bruker Franzen Analytik GmbH 1996. 